UNIVERSIDADE DE SÃO PAULO

FACULDADE DE ECONOMIA, ADMINISTRAÇÃO E CONTABILIDADE DEPARTAMENTO DE CONTABILIDADE E ATUÁRIA PROGRAMA DE PÓS-GRADUAÇÃo EM CIÊNCIAS CONTÁBEIS

A RELAÇÃO DO CONSELHO FISCAL COMO COMPONENTE DE CONTROLE NO GERENCIAMENTO DE RESULTADOS CONTÁBEIS.

Adriana Cristina Garcia Trapp

Orientador: Alexsandro Broedel Lopes

SÃo PAULO 
Profa. Dra. Sueli Vilela

Reitora da Universidade de São Paulo

Prof. Dr. Carlos Roberto Azzoni

Diretor da Faculdade de Economia, Administração e Contabilidade

Prof. Dr. Fábio Frezatti

Chefe do Departamento de Contabilidade e Atuária

Prof. Dr. Edgard Bruno Cornachione Jr.

Coordenador do Programa de Pós-Graduação em Ciências Contábeis 


\section{A RELAÇÃO DO CONSELHO FISCAL COMO COMPONENTE DE CONTROLE NO GERENCIAMENTO DE RESULTADOS CONTÁBEIS.}

Tese apresentada ao Departamento de Contabilidade e Atuária da Faculdade de Economia, Administração e Contabilidade da Universidade de São Paulo como requisito para a obtenção do título de Doutor em Ciências Contábeis.

Orientador: Prof. Dr. Alexsandro Broedel Lopes

\section{SÃO PAULO}


Tese defendida e aprovada no Departamento de Contabilidade e Atuária da Faculdade de Economia, Administração e Contabilidade da Universidade de São Paulo - Programa de Pós-Graduação em Ciências Contábeis, pela seguinte banca examinadora:

\section{FICHA CATALOGRÁFICA}

Elaborada pela Seção de Processamento Técnico do SBD/FEA/USP

Trapp, Adriana Cristina Garcia

A relação do conselho fiscal como componente de controle no gerenciamento de resultados contábeis / Adriana Cristina Garcia Trapp. -- São Paulo, 2009.

$133 \mathrm{p}$.

Tese (Doutorado) - Universidade de São Paulo, 2009

Bibliografia.

1. Lucros (Contabilidade) 2. Conselho fiscal 3. Governança corporativa I. Universidade de São Paulo. Faculdade de Economia, Administração e Contabilidade II. Título.

$$
\text { CDD - } 657.48
$$


Agradeço a Deus por tudo que me foi permitido e por todo o precioso conhecimento adquirido.

Gostaria de agradecer ao corpo docente desta faculdade pela formação que me foi proporcionada, e que contribuiu para definir a profissional que hoje sou.

Ao meu orientador professor doutor Alexsandro Broedel Lopes, meus sinceros agradecimentos pelos direcionamentos efetuados e pela paciência que demonstrou em seus ensinamentos.

Aos professores doutores Gilberto de Andrade Martins e Luiz João Corrar pelo suporte e auxílio que me foram prestados nos momentos de reflexão quando este era ainda um projeto.

Aos professores doutores Luiz Nelson Guedes de Carvalho e Alexandre di Miceli da Silveira pelas valiosas críticas e contribuições para aprimoramento desta tese.

Agradeço ao meu marido Thomaz e a minha filha Stéphanie pela compreensão compartilhada nos momentos em que precisei estar ausente e pela ajuda na obtenção da base de dados.

Ao Henri Penchas e Sérgio Ribeiro da Costa Werlang expresso meu profundo agradecimento por todo apoio e incentivos fornecidos, sem os quais não seria possível a conclusão deste projeto. 
"Para realizar grandes conquistas, devemos não apenas agir, mas também sonhar; não apenas planejar, mas também acreditar." Anatole France 


\section{RESUMO}

O gerenciamento de resultados surge nas organizações no momento em que os gestores responsáveis pelas informações contábeis fazem uso de julgamento para alterar os relatórios financeiros externos, com o intuito de intervenção proposital no processo e obtenção de algum ganho pessoal. Nesse contexto, tornam-se necessários mecanismos que possam assegurar que os interesses dos acionistas não sejam preteridos pelos interesses dos administradores, mecanismos estes que formam a governança corporativa. A estrutura de propriedade e controle, o conselho de administração, o conselho fiscal, a auditoria independente são alguns exemplos dos instrumentos que compõem referida governança. Sendo o conselho fiscal responsável pela fiscalização dos atos dos administradores e tendo que oferecer sua opinião quanto aos demonstrativos financeiros examinados pelo auditor externo, verifica-se claramente sua intersecção com práticas de governança corporativa e, conseqüentemente, com possíveis níveis de gerenciamento de resultados. Dessa forma, esta tese tem por objetivo avaliar se a existência de conselho fiscal nas empresas de capital aberto brasileiras influencia no nível de gerenciamento de resultados praticados, e também analisar se a qualificação contábil dos conselheiros fiscais também exerce influência sobre os números reportados. Ademais, tem-se como objetivo secundário verificar se outros componentes de governança corporativa também teriam relacionamento com os níveis de gerenciamento de resultados. A pesquisa estatística foi dividida em duas partes: a primeira com o propósito de analisar o relacionamento do conselho fiscal e demais instrumentos de governança corporativa com as métricas de gerenciamento de resultados; a segunda teve o propósito de verificar se os resultados de estudos realizados em outros países entre instrumentos de governança e gerenciamento de resultados teriam conclusões similares se aplicados ao Brasil. As hipóteses foram testadas com base em regressões lineares simples e análise de dados em painel (utilizando as técnicas de efeitos fixos e de efeitos aleatórios). Os resultados encontrados sugerem que a existência de conselho fiscal está relacionada a menores níveis de gerenciamento de resultados e, quanto mais estruturada a governança corporativa da empresa, a qualificação do conselheiro fiscal também influencia na melhoria da informação contábil divulgada ao público externo. 


\begin{abstract}
The earnings management appears in the organizations when the decisions are taken by the responsible managers for the accounting data to change the external financial reports, whose intention is to interfere in the process and obtain personal advantage. In this context, it is necessary mechanisms to guarantee that the managers' interests do not disregard the shareholders' interests. The structure of property and control, the board of directors, the fiscal council, the independent audit are some examples of instruments that integrate the governance. Being the fiscal council responsible for the inspection of the administrator's actions and having to offer their opinions on the financial reports reviewed by the external auditors, it is clear its link with corporate governance practices consequently, with possible earnings management levels. Being so, this thesis objective is to value whether the fiscal council in the organizations negotiated in the Brazilian open market influences the practiced earnings management level, as well as, to analyze whether the fiscal council accountancy qualification influences the reported figures too. In addition, the secondary objective is to verify whether other corporate governance components would be related to earnings management levels. The statistic research was divided into two parts: firstly, with the proposal of analyzing the relationship of fiscal council and other corporate governance mechanisms with the earnings management metrics; secondly, it had the intention to verify whether the results of studies held in other countries between the governance instruments and earnings management would have similar conclusions if applied in Brazil. The hypotheses were tested by applying simple linear regressions and panel data techniques (using Random Effects and Fixed Effect procedures). The results found suggest that the existence of a fiscal council is related to lower levels of earnings management, and the more the structure of corporate governance is, the fiscal council qualification influences the improvement of accountancy information reported to the stakeholders.
\end{abstract}




\section{SUMÁRIO}

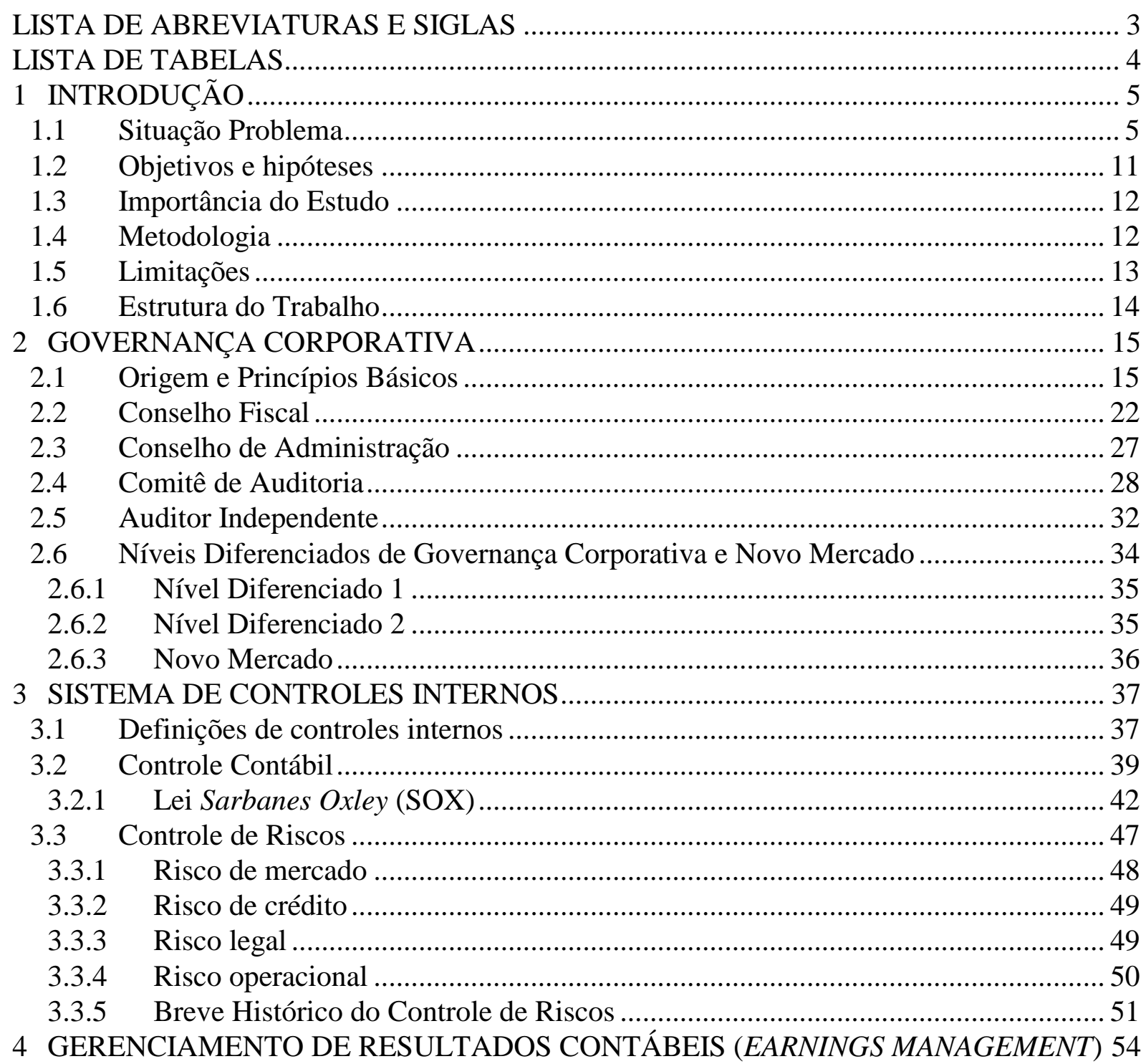

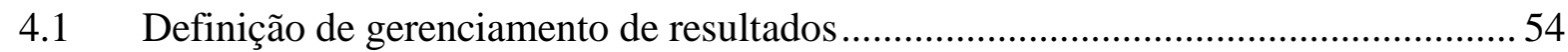

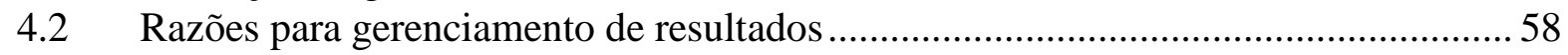

4.2.1 Motivação por plano de incentivo (bonus plan) ...................................................... 59

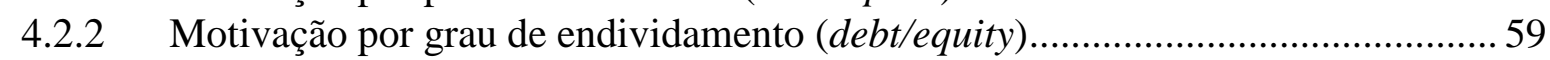

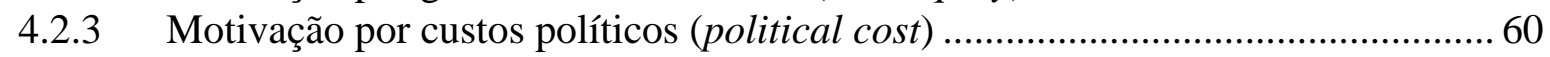

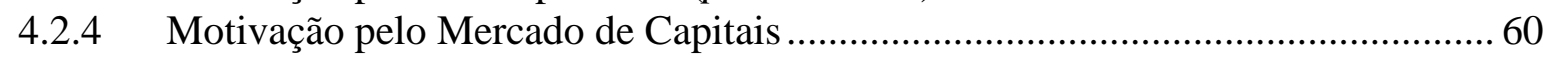

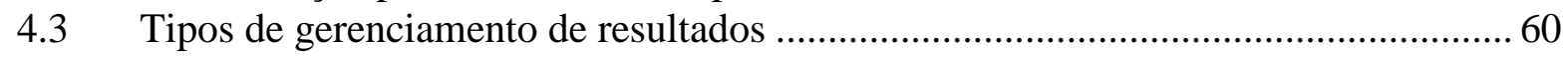

4.4 Metodologias para evidenciação de gerenciamento de resultados ............................. 62

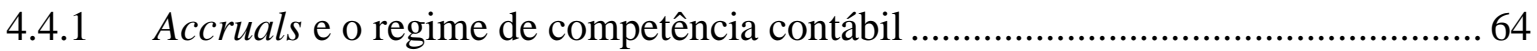

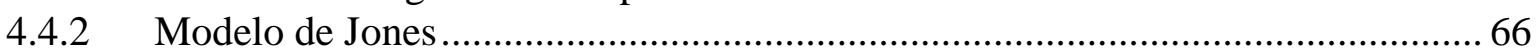

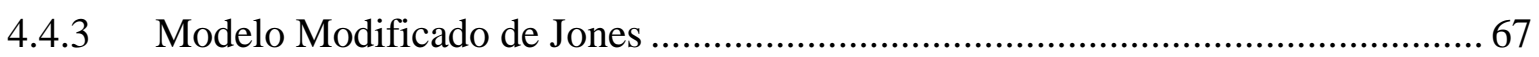

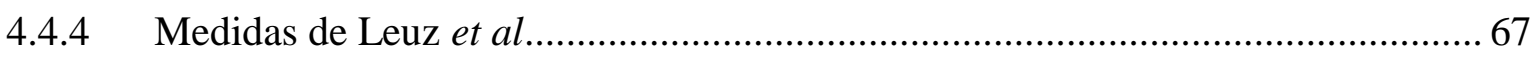

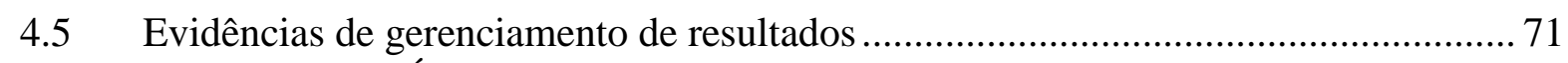

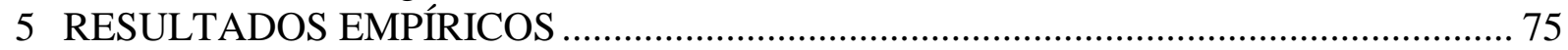

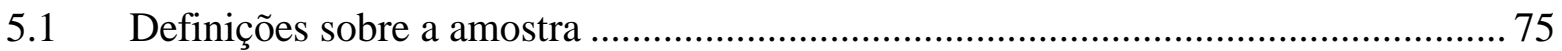

5.2 Análise estatística dos resultados - métricas de Leuz et al (2002) ............................ 82 
5.3 Análise estatística dos resultados - modelo modificado de Jones (1999) ................ 100

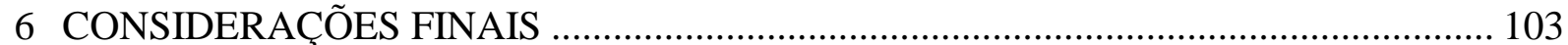

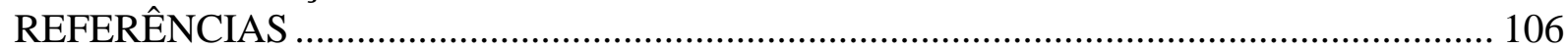
APÊNDICE 1 - COMMITTEE OF SPONSORING ORGANIZATIONS OF THE TREADWAY

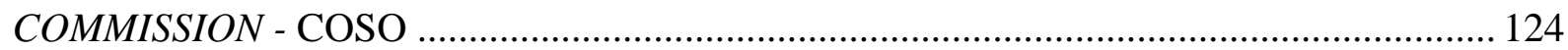
APÊNDICE 2 - EMPRESAS UTILIZADAS NA PESQUISA ........................................... 128 
LISTA DE ABREVIATURAS E SIGLAS

ADR: American Depositary Receipts

AICPA: American Institute of Certified Public Accountants

BACEN: Banco Central do Brasil

BIS: Bank for International Settlements

BOVESPA: Bolsa de Valores do Estado de São Paulo

CEO: Chief Executive Officer

CFC: Conselho Federal de Contabilidade

CFO: Chief Finance Officer

CGPC: Conselho de Gestão da Previdência Complementar

CMN: Conselho Monetário Nacional

COSO: Committee of Sponsoring Organizations

CPA: Certified Public Accountants

CVM: Comissão de Valores Mobiliários

FASB: Financial Accounting Standards Board

GAAP: Generally Accepted Accounting Principles

IBGC: Instituto Brasileiro de Governança Corporativa

NASD: National Association of Securities Dealers

NYSE: New York Stock Exchange

OCDE: Organization for Economic Co-operation and Development

PCAOB: Public Company Accounting Oversight Board

SAS: Statements on Auditing Standards

SEC: Security Exchange Commission

SOX: Lei Sarbanes Oxley

SUSEP: Superintendência de Seguros Privados 


\section{LISTA DE TABELAS}

Tabela 1- Estatística descritiva 83

Tabela 2 - Distribuição de freqüências: conselho fiscal e especialista contábil. 84

Tabela 3 - Métricas de gerenciamento de resultados para cada empresa (classificadas por EM6)

Tabela 4 - Métricas de gerenciamento de resultados por setor econômico (classificadas por EM6).

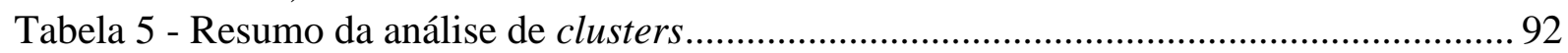

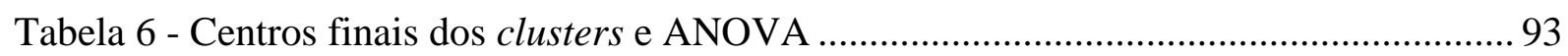

Tabela 7 - Empresas do cluster 1 (classificadas por EM6) …............................................... 94

Tabela 8 - Empresas do cluster 2 (classificadas por EM6) ................................................. 95

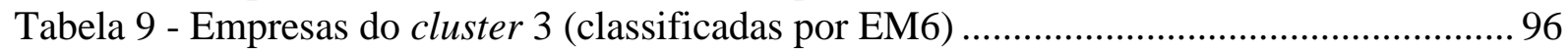

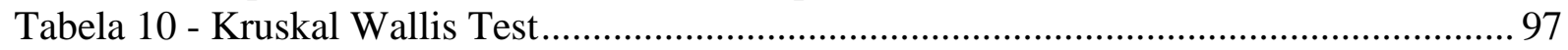

Tabela 11 - Regressões entre métricas de gerenciamento de resultados e possíveis mecanismos de governança corporativa....................................................................... 98

Tabela 12 - Regressões entre métrica de gerenciamento de resultados e possíveis mecanismos de governança corportativa 


\section{INTRODUÇÃO}

\subsection{Situação Problema}

A base conceitual da Contabilidade está centrada em dois principais itens qualitativos que tornam a informação contábil útil para a tomada de decisão: relevância e confiabilidade (FASB, 1980). A relevância pode ser entendida como a informação pertinente à questão em análise, ou seja, a informação que faz a diferença numa tomada de decisão. Já a confiabilidade, de forma geral, garante que a informação seja livre de erro e represente fielmente o que visa a representar. Contudo, para que a informação seja livre de erro, é necessário que todo o sistema, ou toda a cadeia de valor da companhia, não contenha viés, que seja confiável.

Visando à maximização da utilidade da informação contábil, freqüentemente os gestores necessitam fazer escolhas entre os métodos contábeis e decidir sobre os critérios de mensuração (custo histórico, custo corrente, valor presente do fluxo de caixa futuro entre outros). Em momentos onde os custos precisam ser reconhecidos, as decisões giram em torno do período e do método de alocação, sendo a depreciação um bom exemplo. Dessa forma, as escolhas estão relacionadas, em muitas ocasiões, ao julgamento dos gestores, e deveriam ser feitas levando-se em consideração a agregação de valor nos demonstrativos financeiros. Conseqüentemente, a questão principal é como o responsável pelos dados contábeis vai utilizar seu poder de decisão para realizar a escolha mais adequada.

É nesse momento, de tomada de decisão contábil, que pode surgir o gerenciamento de resultados por parte dos gestores responsáveis pela informação, com o intuito de intervenção proposital no processo de elaboração das demonstrações financeiras externas, com a intenção de obter algum ganho pessoal (SCHIPPER, 1989, p. 92). Ademais, conforme acrescenta Healy (1998, p. 6) os administradores podem utilizar julgamentos para alterar os relatórios financeiros ou para enganar alguns stakeholders sobre a performance econômica da 
companhia, ou para influenciar os resultados contratuais que dependem dos números contábeis reportados.

Levando-se em consideração os componentes relatados acima, quer sejam, o "ato intencional", a "obtenção de algum benefício" e a "atitude de enganar" verifica-se a existência de conflitos de interesses entre os acionistas e os dirigentes das empresas. Jensen e Meckling (1976) desenvolveram os primeiros estudos sobre as divergências de interesses entre acionistas, administradores, credores e funcionários, conhecidas como conflito de agência. A idéia está centrada na figura de agentes e principais, sendo que o conflito de agência surge quando o agente (por exemplo, o administrador) deixa de representar os interesses do principal (o acionista, por exemplo) em prol dos seus interesses particulares.

Nesse cenário de conflito de agência, tornam-se necessários mecanismos que assegurem que o interesse do proprietário não seja sobreposto pelos interesses dos administradores. Surge, assim, a governança corporativa que segundo Silveira (2004, p. 12-13):

[...] pode ser vista como o conjunto de mecanismos que visam a aumentar a probabilidade dos fornecedores de recursos garantirem para si o retorno sobre seu investimento. $\mathrm{O}$ risco de os recursos dos investidores não serem bem empregados ou serem desviados decorre fundamentalmente da existência de uma situação de separação entre propriedade e controle, onde as pessoas que fornecem capital não participam diretamente das decisões corporativas. Esta situação ocorre na maioria das grandes corporações, onde os gestores, executivos profissionais em companhias com estrutura de propriedade pulverizada ou acionistas em companhias com estrutura de propriedade concentrada, não carregam todo o ônus financeiro das decisões.

A estrutura de propriedade e controle, o conselho de administração, o conselho fiscal, a auditoria independente, o sistema de controles internos são alguns exemplos dos mecanismos que compõem a governança corporativa. Ademais, conforme Lopes (2008, p.117), os resultados contábeis têm um papel essencial na governança corporativa, uma vez que a manipulação intencional dos resultados com o intuito de enganar terceiros pode ter importantes efeitos no valor e uso dos números contábeis. Se os investidores não confiam na situação econômica da empresa relatada pelos relatórios contábeis, eles terão que recorrer a outros mecanismos, possivelmente mais custosos, para monitorar os administradores. Lopes (2008) também ressalta que empresas que adotam voluntariamente padrões superiores de governança corporativa seriam menos afetadas por atividades de gerenciamento de resultados contábeis. 
Nesse contexto de importância da qualidade da informação contábil, da confiabilidade e da governança corporativa como instrumento de controle o principal propósito desta tese é verificar se referida qualidade é afetada pelas estruturas de governança existentes nas empresas. Utilizou-se como proxy de qualidade da informação contábil métricas de gerenciamento de resultados, ou earnings management, uma vez que a existência de níveis de gerenciamento de resultados sinaliza lucros de baixa qualidade que não refletem com precisão a performance atual e futura da empresa. Contudo, existiria um instrumento de governança que pudesse ser utilizado como proxy para confiabilidade das informações contábeis divulgadas?

Em sendo o conselho fiscal responsável pela fiscalização dos atos dos administradores, bem como do conselho de administração, e sendo o único componente de governança corporativa eleito pela Assembléia Geral com a função obrigatória de emitir opinião quanto aos demonstrativos financeiros examinados pelo auditor externo, verifica-se sua intersecção direta com práticas de governança corporativa e, conseqüentemente, com possíveis níveis de gerenciamento de resultados.

Embora o conselho de administração tenha como uma de suas funções o papel de controlar, ou fiscalizar, importante salientar que referida fiscalização não se confunde com o conselho fiscal, pois o primeiro exerce funções deliberativas e de cunho administrativo (TOLEDO, 1999, p. 38). Ou ainda, conforme afirmam Andrade e Rosseti (2006, p. 264) “[...] enquanto os atos do Conselho de Administração estão voltados para a gestão, sendo esta exercida pela Diretoria Executiva, as funções do Conselho Fiscal estão voltadas para o exame, a verificação, a fiscalização e a avaliação das contas e dos atos da administração".

O conselho fiscal já estava previsto em lei brasileira desde o ano de 1976 (Lei n. ${ }^{\circ}$ 6.404) e foi ratificado também no novo Código Civil. Logo, trata-se de um dos mais antigos instrumentos de controle, sendo que poucas pesquisas empíricas têm sido realizadas vertendo sobre o tema. Silva (2000, p. 20), em um dos poucos trabalhos acadêmicos sobre o conselho fiscal, assim se pronuncia:

O Conselho Fiscal bem regulado e atuante acaba desempenhando o papel quase que de um poder moderador, servindo de anteparo a evitáveis querelas, afinando o entrosamento entre minoritários e os detentores do controle acionário. Um Conselho Fiscal atuante evitará que o único desaguadouro 
das pendências sociais seja o Poder Judiciário, que, como sabemos, é tecnicamente desaparelhado para dar solução rápida e eficaz à maioria dos litígios que brotam da sociedade anônima. Neste caso, o que se tem é uma jurisprudência escassa e vacilante.

Constantemente o mercado tem discutido sobre a obrigatoriedade ou não do conselho fiscal, como preconizado na lei nas sociedades por ações, com argumentos que vão desde a conclusão por sua utilidade para os minoritários até conclusão de uma função apenas para cumprir protocolo exigido por legislador. Silva (2000, p. 19) acrescenta que os adeptos à extinção do conselho fiscal são os que se contentam com a presença da auditoria independente. Apesar dessas controvérsias, pouca ou nenhuma pesquisa tem sido feita no sentido de verificar tais afirmações e comportamentos, tornando o propósito desta tese relevante para a literatura.

Por outro lado, é importante ressaltar que embora seja possível verificar o relacionamento do conselho fiscal com as demonstrações contábeis, mesmo que indiretamente, os demais instrumentos de governança corporativa também teriam influência sobre o gerenciamento de resultados e, conseqüentemente, sobre a informação contábil?

Conforme citado anteriormente, a contabilidade está intimamente ligada aos mecanismos de governança corporativa, entre eles, aos controles internos. O AICPA, American Institute of Certified Public Accountants, assim se pronunciou pela primeira vez quanto ao conceito de controle interno nas áreas contábil e administrativa na SAS - 29 - Internal Control de 1958:

O controle interno, no sentido amplo, compreende controles que se podem caracterizar como contábeis ou como administrativos, como segue:

a) controles contábeis compreendem o plano de organização e todos os métodos e procedimentos referentes e diretamente relacionados com a salvaguarda do ativo e a fidedignidade dos registros financeiros. Geralmente, compreendem controles tais como: os sistemas de autorização a aprovação, separação entre tarefas relativas à manutenção de registros, elaboração de relatórios e aquelas que dizem respeito à operação ou custódia do ativo, controles físicos sobre o ativo e auditoria interna;

b) controles administrativos são os que compreendem o plano de organização e todos os métodos e procedimentos referentes principalmente à eficiência operacional e obediência às diretrizes administrativas, e que normalmente se relacionam apenas indiretamente com os registros contábeis e financeiros. Em geral, incluem controles como análises estatísticas, estudos de tempo e movimento, relatórios de desempenho, programas de treinamento de empregados, e controles de qualidade. 
É possível verificar o quão ampla era a abrangência de um sistema de controles internos na definição inicial do AICPA. Entretanto, com os escândalos ocorridos no final do século XX e início do século XXI envolvendo grandes empresas, bem como os desastres financeiros ocorridos relacionados à necessidade de controle do risco operacional em alguns bancos, entre eles, Daiwa Bank, Barings Bank e Sumitomo Corporation, que, conforme King (2001, p.24), os quais acumularam perdas na ordem de US\$ 1,1 bilhão, de US\$ 1,4 bilhão e de US\$1,8 bilhão, respectivamente, decorrente de posições não autorizadas exercidas por um único operador, ficou evidente para o mercado e, consequentemente, para os órgãos reguladores, a necessidade de se estabelecerem regulamentações mais rígidas e que pudessem aprimorar cada vez mais os sistemas de controles internos.

Nesse sentido, o Comitê da Basiléia sobre Fiscalização Bancária empreendeu esforços para se adaptar às novas necessidades de controle de exposições ao risco dessas entidades, de maneira a continuar promovendo segurança e solidez no sistema financeiro (CARVALHO et al, 2004, p. 265). O resultado disso foi a publicação do Novo Acordo de Capital da Basiléia em 2001.

Na busca pelo mesmo objetivo, ou seja, de restabelecer a confiança no mercado, os Estados Unidos promulgaram a lei Sarbanes-Oxley (SOX) a qual, entre outros aspectos, empreendeu uma grande ênfase para as severas punições aos administradores e auditores externos em casos de fraudes. Dentre as extensas disposições da referida lei, pode-se citar:

a) Incumbência do conselho de administração, por meio de seu comitê de auditoria, de supervisionar a contratação de auditores externos e de assegurar que seus trabalhos são realizados de forma rigorosamente independente, sem influência da gestão da empresa;

b) Estabelecimento de que é de responsabilidade da administração (CEO - Chief Executive Officer e CFO - Chief Financial Officer) implantar e manter adequada a estrutura e procedimentos de controle interno voltados para os relatórios financeiros;

c) Estabelecimento de que referido sistema de controle interno para o relatório financeiro, seja revisado, reavaliado e testado continuamente pela administração, que deve incluir nos demonstrativos do balanço, um relatório específico de sua avaliação, o qual deve ser atestado pelo auditor externo;

d) Estabelecimento de que para atestar o relatório da administração sobre os controles internos, o auditor externo deve auditar os procedimentos adotados pela Administração 
para o desenho e teste dos controles, e auditar os controles internos totalmente integrados com a auditoria das demonstrações financeiras.

No Brasil, as exigências quanto à necessidade de controles internos efetivos e eficazes não foram diferentes. Em 1998, o Conselho Monetário Nacional emitiu a Resolução CMN no 2.554 com o objetivo de aumentar a qualidade da governança corporativa nas instituições financeiras. Em 2004, emitiu a Resolução CMN nº 3.198 que, entre outras disposições, estabelece a obrigatoriedade do Comitê de Auditoria para instituições com patrimônio líquido de referência igual ou superior a R \$ 1 bilhão.

Demonstrando a mesma preocupação do CMN e versando sobre os mesmos temas, quer sejam estrutura de controles internos e criação de comitê de auditoria entre outras disposições, o Conselho Nacional de Seguros Privados emitiu a Resolução CNSP n ${ }^{\circ} 118$ em dezembro de 2004 e a SUSEP, Superintendência de Seguros Privados, publicou as circulares nºs. 249 e 280 também em 2004.

Assim, analisando-se a legislação existente, tanto no âmbito nacional quanto internacional, é possível verificar que vários organismos reguladores relacionam os demais mecanismos de governança corporativa, além do conselho fiscal, com qualidade e confiabilidade das demonstrações contábeis, remetendo esta tese as seguintes questões de pesquisas:

I. A existência de conselho fiscal nas empresas brasileiras de capital aberto influencia no nível de gerenciamento de resultados praticado?

II. A composição do conselho fiscal (quantidade de conselheiros) está relacionada com informações contábeis de melhor qualidade?

III. A formação em ciências contábeis de alguns membros do conselho fiscal é relevante no nível de gerenciamento de resultados?

IV. O nível de governança corporativa praticado nas empresas influencia na qualidade das informações contábeis?

V. Existem diferenças no gerenciamento de resultados entre as empresas que apresentam níveis de estrutura de governança corporativa distintos? 


\subsection{Objetivos e hipóteses}

Objetivo geral:

Verificar se há relacionamento entre a existência de conselho fiscal e gerenciamento de resultados contábeis.

Objetivos específicos:

a) Analisar se a composição e a formação contábil ${ }^{1}$ dos conselheiros impactam o nível de gerenciamento de resultados contábeis;

b) Investigar se os seguintes componentes de governança corporativa também contribuem no gerenciamento de resultados contábeis:

- Existência de "índice de governança Bovespa";

- $\quad$ Existência de ADRs;

- Investidores institucionais;

- $\quad$ Comitê de auditoria;

- Composição do board (conselho de administração);

- Direitos dos acionistas;

- $\quad$ Evidenciação;

- $\quad$ Empresa de auditoria externa (big four).

Hipóteses:

$\mathrm{H}_{0 \mathrm{a}}$ : As companhias abertas brasileiras que apresentam conselho fiscal têm menores níveis de gerenciamento de resultados;

$\mathrm{H}_{0 \mathrm{~b}}$ : A existência de conselheiros com formação contábil diminui os níveis de gerenciamento de resultado;

\footnotetext{
1 Neste trabalho será considerada formação contábil bacharelado ou mestrado ou doutorado em ciências contábeis.
} 
$\mathrm{H}_{0 c}$ : Outros componentes considerados relevantes pela literatura de governança corporativa também influenciam nos níveis de gerenciamento de resultados.

\subsection{Importância do Estudo}

A importância do tema centra-se no fato de existir extensa literatura internacional sobre gerenciamento de resultados, mas no Brasil ainda ser incipiente, sendo que a qualidade das demonstrações contábeis influencia nos mecanismos de gestão e controle das empresas. De acordo com Bushman et al (2000) a contabilidade reduz a assimetria da informação de forma que modelos contábeis menos robustos fazem com que as empresas utilizem outros mecanismos de governança corporativa para controlar as ações dos administradores.

Ademais, não existem pesquisas nacionais empíricas sobre o relacionamento do conselho fiscal e demais mecanismos de governança corporativa com gerenciamento de resultados contábeis. O que se pretende, assim, é auxiliar os investidores e analistas no processo decisório, bem como contribuir com os órgãos reguladores no processo de análise e proposição de mudanças legais com o intuito de melhorar a qualidade informacional.

\subsection{Metodologia}

Utilizar-se-á o método de pesquisa empírico-analítica que, conforme define Martins (1994, p. 26) trata-se de:

[...] abordagens que apresentam em comum a utilização de técnica de coleta, tratamento e análise de dados marcadamente quantitativas. Privilegiam estudos práticos. Suas propostas têm caráter técnico, restaurador e incrementalista. Têm forte preocupação com a relação causal entre variáveis. A validação da prova científica é buscada através de testes dos instrumentos, graus de significância e sistematização das definições operacionais.

De forma geral, o presente estudo está fundamentado no modelo de Jones (1991) e nas métricas de Leuz et al (2002) para o cálculo de gerenciamento de resultados. O primeiro modelo utiliza regressões para estimar os accruals não discricionários e, por conseqüência, 
estimar indiretamente o valor dos accruals discricionários; o segundo método é composto de métricas que procuram identificar a variabilidade e a suavização dos lucros reportados. As hipóteses serão testadas com base em regressões lineares simples e análise de dados em painel (utilizando as técnicas de efeitos fixos e de efeitos aleatórios) nas quais as variáveis dependentes serão representadas pelas métricas de gerenciamento de resultados e as variáveis independentes representar-se-ão pelos componentes de governança corporativa, sendo as hipóteses testadas em termos dos coeficientes encontrados.

Os dados contábeis foram obtidos na base de dados Economática ${ }^{\circledR}$ e correspondem ao período de 2002 a 2007. As informações sobre controles internos e governança corporativa para o mesmo período foram obtidas na CVM e BOVESPA por meio do sistema DIVEXT, além de consulta aos sites institucionais.

Para a realização dos testes estatísticos foram utilizados os programas Statistical Package for Social Science 10.0 for Windows (SPSS), Stata/SE 10.0, Eviews 6.0 e Microsoft Excel.

\subsection{Limitações}

Por se tratar de trabalho empírico, generalizações devem ser feitas cuidadosamente, de forma que as conclusões fiquem restritas à amostra utilizada. Ademais, devido à seleção da amostra, quer seja, utilização das mesmas empresas nos períodos analisados, existe a hipótese de seleção viesada de empresas com determinado tipo de características, o que de certa forma é amenizado, pois não houve nenhum critério diferenciado para referida seleção, a não ser a existência de dados em todos os anos analisados.

Importante salientar que as limitações inerentes aos modelos utilizados nesta tese para cálculo do gerenciamento de resultados estão intrínsecas, sendo que não se pretende provar a efetividade de tais modelos, mas utilizar-se de pesquisas acadêmicas que já o fizeram, reproduzindo tais estudos para o mercado brasileiro. 


\subsection{Estrutura do Trabalho}

O presente estudo está dividido em seis capítulos. O capítulo a seguir descreve a origem e os princípios de melhores práticas de governança corporativa, dissertando especificamente sobre conselho fiscal, conselho de administração, comitê de auditoria, auditoria independente e níveis de governança. Já o capítulo 3 fornece os critérios para controles internos e sua estruturação, dividindo-o em controle contábil e controle de riscos. No capítulo 4, tem-se a definição de gerenciamento de resultados, apresentando-se suas causas, tipos e conseqüências. Também são demonstrados os modelos utilizados na literatura para análise do gerenciamento. O capítulo 5 detalha a seleção da amostra, a estatística descritiva e apresenta os resultados estatísticos obtidos. As conclusões e sugestões para futuras pesquisas encontram-se no capítulo 6. 


\section{GOVERNANÇA CORPORATIVA}

\subsection{Origem e Princípios Básicos}

A expressão governança corporativa tem sido muito utilizada no mercado de capitais e, em termos gerais, representa o relacionamento entre os acionistas e os dirigentes das empresas, ou seja, a separação entre propriedade e controle exigiu a criação de mecanismos que assegurassem que o interesse do proprietário não fosse sobreposto pelos interesses dos administradores. Assim, a governança surge relacionada com o conflito de agência, bem como com a assimetria informacional existente entre os participantes.

A respeito disso, Jensen e Meckling (1976) desenvolveram os primeiros estudos sobre o conflito de agência retratando as divergências de interesses entre acionistas, administradores, credores e funcionários. A idéia está centrada na figura de agentes e principais, sendo que o conflito de agência surge quando o agente (por exemplo, o administrador) deixa de representar os interesses do principal (o acionista, por exemplo) em prol dos seus interesses particulares.

Logo, o conflito de agência surge quando os agentes ligados à empresa possuem interesses divergentes dos acionistas. Por conseguinte, o acionista deve ter o maior número possível de instrumentos para evitar que os interesses pessoais dos administradores prejudiquem a organização, gerando, assim, "custos de agência", que segundo os mesmos autores podem ser exemplificados como: custo na elaboração de contratos entre o principal e o agente; custo pelo monitoramento das atividades desenvolvidas pelos agentes, bem como os gastos proporcionados por estes para promover a transparência de informações; "perdas residuais" decorrentes da redução da riqueza dos acionistas devido aos interesses divergentes dos agentes quanto às decisões que poderiam maximizar a riqueza do principal.

Com relação às perdas residuais decorrentes de decisões dos gestores não maximizadoras da riqueza dos acionistas, Silveira (2004, p. 32-33) retrata referidas decisões em dois tipos: decisões que maximizam a riqueza dos acionistas (tipo 1); e decisões que maximizam a utilidade pessoal dos gestores ou agentes (tipo 2), sendo que a diferença entre as duas decisões 
representa um custo para a empresa decorrente do problema de agência. A figura a seguir explicita o conceito.

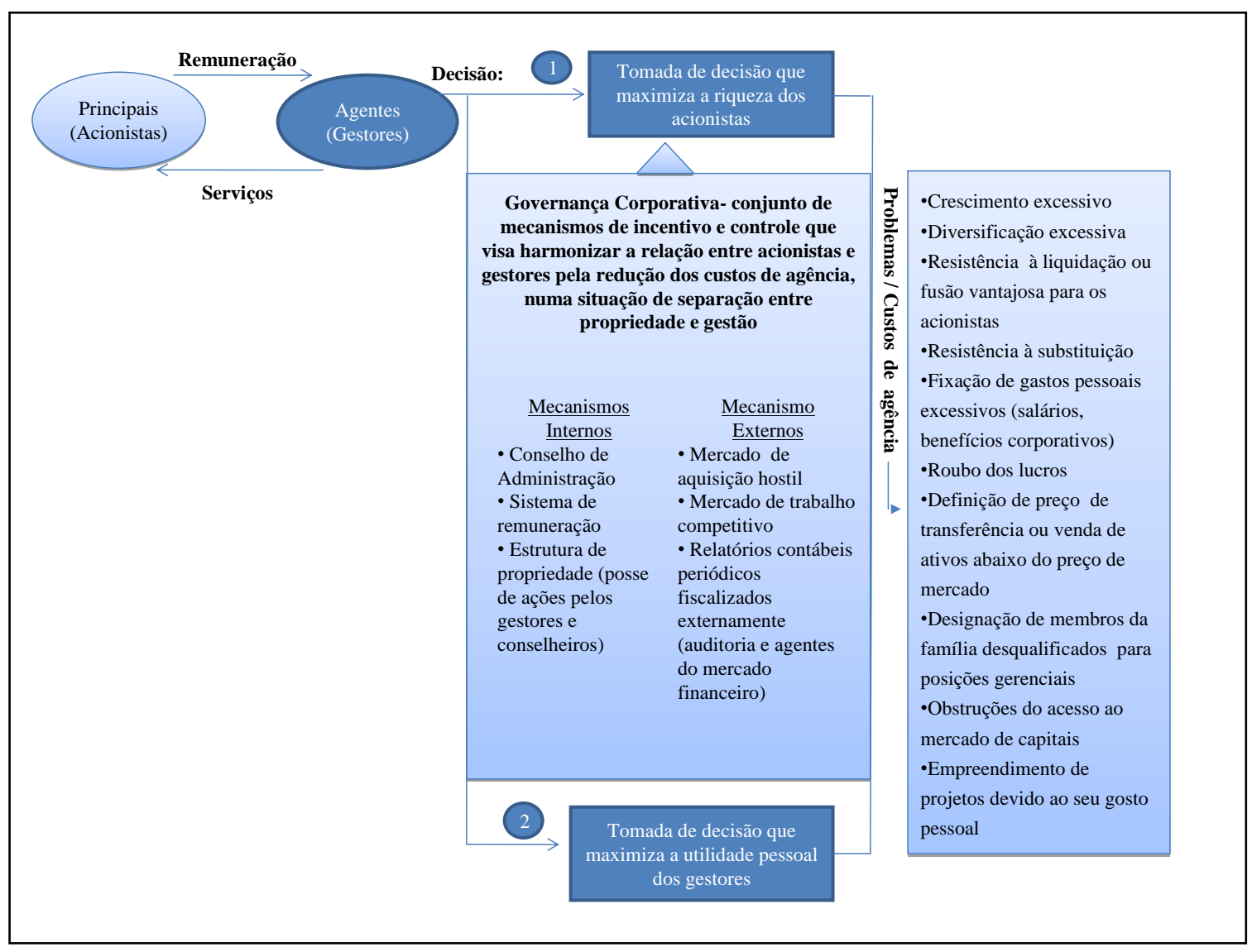

Ilustração 1 - O problema de agência e a governança corporativa Fonte: Adaptado de Silveira (2004, p.32)

A existência do custo de agência, consoante Eisenhardt (1985), leva os acionistas à tentativa de monitorar os agentes contratados, reunindo informações sobre suas decisões ou comportamentos.

Importante ressaltar que o conflito de agência é um dos componentes da teoria contratual da firma, na qual a firma é um conjunto de contratos entre clientes, trabalhadores, executivos e fornecedores de material e capital (JENSEN, 2001, p.1) e cada participante contribui com algo e recebe em troca a sua parte. Logo, o funcionamento adequado da empresa depende do equilíbrio contratual estabelecido.

Nesse contexto, a contabilidade possui funções na coordenação dos vários contratos existentes, a saber (SUNDER, apud LOPES e MARTINS, 2005, p. 33-34): 
- Mensurar a contribuição de cada um dos participantes nos contratos;

- Mensurar a fatia a que cada um dos participantes tem direito no resultado da empresa;

- Informar os participantes a respeito do grau de sucesso no cumprimento dos contratos;

- Distribuir informação para todos os potenciais participantes em contratos com a empresa para manter a liquidez dos seus fatores de produção;

- Distribuir algumas informações como conhecimento comum (common knowledge) para reduzir o custo da negociação dos contratos.

Assim, ainda conforme Lopes e Martins (2005, p. 35), “a contabilidade surge para resolver problemas econômicos que não foram adequadamente contemplados pela teoria tradicional da firma". Ressalta-se que cada grupo de interessados na empresa possui uma classe distinta de aspirações e, por conseguinte, demandarão contratos distintos e com características diversas, sendo que a contabilidade precisa adaptar-se a cada uma dessas categorias para que possa fornecer informações realmente úteis.

Volvendo-se ao Brasil no que diz respeito às relações de conflito de agência, estas estão bastante relacionadas a acionistas majoritários e minoritários (ALMEIDA e ROSSETTI, 2006). Ainda, segundo Bernhoeft e Gallo (2004), a alta concentração de propriedade e do controle das companhias, aliada à baixa proteção legal dos acionistas, faz com que a principal relação de conflito de agência seja entre controladores majoritários e minoritários e não entre acionistas e gestores conforme modelo dos países anglo-saxões.

Pesquisas realizadas pelo IBGC (2001), Instituto Brasileiro de Governança Corporativa, e pela Mckinsey \& Company e Korn Ferry International (2001) demonstraram que as empresas brasileiras listadas em bolsa de valores possuem forte concentração das ações com direito a voto, sendo o controle familiar ou compartilhado com poucos investidores, além de pouca clareza na divisão de papéis entre conselho e diretoria e ausência de comitês para tratamento de questões específicas.

Somando-se às divergências de interesses há ainda a assimetria informacional, na qual as informações disponíveis para os agentes e acionistas podem não ser as mesmas, sendo que estes últimos geralmente estão em desvantagem informacional em relação aos altos executivos. A respeito disso Iudícibus e Lopes (2004, p. 172) assim se pronunciam: 
[...] pode-se verificar que a existência de conflitos de agência e da assimetria informacional permeia a atividade das organizações modernas de forma profunda. Não se pode ambicionar a um estudo sério das organizações modernas sem a consideração desses dois fatores, que estão intimamente ligados.

Corroborando com a afirmação acima, Shleifer e Vishny (1997, p.737) citam que a governança corporativa trata das formas pelas quais os fornecedores de financiamento para as empresas asseguram um retorno para referido investimento.

Dessa forma, a governança corporativa, aliada à contabilidade, constitui-se de um sistema de auxílio aos agentes internos e externos para que se certifiquem de que os interesses de ambos estão sendo cumpridos. A figura a seguir, apresentada por Lopes (2008) e adaptada a esta tese, ajuda a esclarecer o papel da contabilidade e dos mecanismos de governança corporativa no relacionamento entre gestores e investidores.

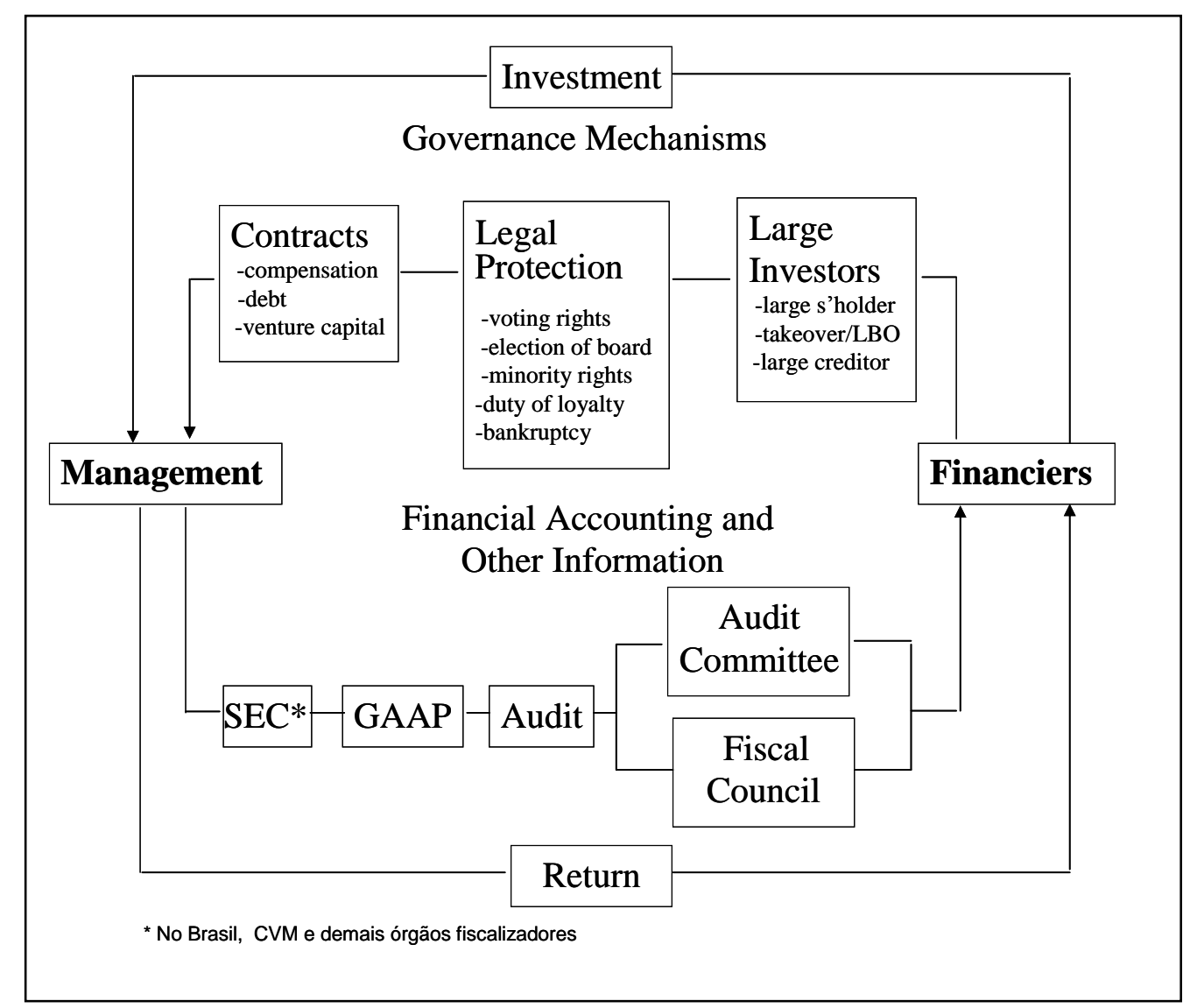

Ilustração 2 - O papel da contabilidade e dos mecanismos de governança corporativa Fonte: Adaptado de apresentação realizada por Lopes na Manchester Business School (2008). 
Resumindo o processo acima, a princípio elaborado para os Estados Unidos, verifica-se que os investimentos realizados em uma determinada empresa são de certa forma protegidos pelos mecanismos de governança antes de serem administrados pelos gestores, sendo que estes, após terem efetivamente tomado as decisões empresariais na busca pelo retorno procurado pelos respectivos investidores são novamente fiscalizados, só que nesse momento, pelos instrumentos contábeis aqui representados pela SEC, Security Exchange Commission, pelos princípios contábeis (GAAP), pela auditoria externa e pelo comitê de auditoria. Adaptando-se o fluxo ao Brasil, no lugar da SEC estão órgãos normatizadores e fiscalizadores tais como CVM, Comissão de Valores Mobiliários, BACEN, Banco Central do Brasil, entre outros, e paralelamente ao comitê de auditoria foi inserido o conselho fiscal.

Contribuindo com o conceito apresentado, no qual existe uma estreita ligação entre os mecanismos de governança e a contabilidade, surge na Inglaterra a primeira referência para os códigos de boas práticas da governança corporativa, o relatório The Financial Aspects of Corporate Governance, que tinha como principal objetivo revisar os aspectos de governança corporativa relacionados às práticas contábeis e relatórios financeiros. Citado relatório foi publicado em dezembro de 1992 pelo Comitê Cadbury, constituído em determinação do Banco da Inglaterra por representantes da Bolsa de Valores de Londres e do Instituto de Contadores Certificados. De acordo com Securato (2006, p. 71):

[...] Surgiu como resposta aos escândalos registrados no mercado corporativo e financeiro da Inglaterra no final dos anos 80 , época em que ocorrem sucessivos escândalos contábeis e o pálido desempenho dos conselhos de administração de grandes empresas sofreu ataques ferozes sob acusação de criar dificuldades para os acionistas.

A princípio, o relatório versava sobre prestação de contas e transparência, contudo, outros temas foram introduzidos ao código conforme as exigências dos investidores. Em julho de 1995, um novo grupo de trabalho, The Greenbury Committee, divulgou um relatório adicionando a necessidade de divulgação da remuneração dos diretores ao código. A consolidação dos dois relatórios surgiu em junho de 1998 por meio do Hampel Committee Report, organizado pela bolsa de valores de Londres, culminando no combined code.

Após o relatório de Cadbury na Inglaterra, novos estudos e relatórios foram publicados em outros países europeus, principalmente após o ano de 1997, sendo que, consoante Dragomir (2008, p. 5), entre 1992 e 1997 apenas a Espanha, Países Baixos e França estabeleceram um 
código de governança. Atualmente, os códigos de governança estão presentes em mais de sessenta países em todos os continentes (SECURATO, 2006, p. 74).

Outro grande trabalho que contribuiu para o fortalecimento da governança corporativa foi o desenvolvido pela OCDE, Organization for Economic Co-operation and Development, inspirada na forte correlação entre a mobilização de mercados de capitais maduros e confiáveis, o crescimento dos negócios corporativos e o desenvolvimento econômico das nações (ANDRADE E ROSSETTI, 2006, p. 169). Por meio da criação de um grupo, Business Sector Advisory Group on Corporate Governance, o trabalho iniciado em 1998 foi concluído em maio de 1999 no documento Principles of Corporate Governance. Segundo Almeida e Rossetti (2006, p. 171), suas principais conclusões foram:

- $\quad$ Não existe um modelo único de governança corporativa;

- As corporações necessitam inovar e adaptar suas práticas de governança corporativa para se manterem competitivas;

- Os governos também têm responsabilidade na criação de uma estrutura reguladora que permite que os mercados funcionem de maneira eficaz e que atenda os acionistas e demais partes interessadas;

- As práticas de governança corporativa são definidas em cada país pelos órgãos reguladores, as empresas e seus acionistas;

- Os princípios têm caráter evolutivo e devem ser revistos sempre que ocorrerem mudanças significativas, dentro ou fora das organizações;

- $\quad$ A integridade do mercado e o desempenho econômico dos países são assegurados pelos princípios de governança.

Em 2002, o Steering Group, grupo permanente de orientação sobre governança corporativa da OCDE, iniciou revisão no material finalizado em 1999 para "deixá-lo em linha com a evolução e experiência acumulada nos Estados-Membros da OCDE e países terceiros" (OCDE, 2004).

A última versão dos princípios abrange seis áreas: assegurar a base para um enquadramento eficaz da governança corporativa; os direitos dos acionistas e exercício dos direitos; o 
tratamento eqüitativo dos acionistas; o papel dos stakeholders ${ }^{2}$ na governança corporativa; divulgação de informação e transparência; e as responsabilidades do conselho de administração. Por serem básicos e não exaustivos, os princípios demonstram-se relevantes no contexto legal, econômico e social.

Reportando-se ao Brasil, Souza (2004) elucida que a governança pode ser vista sob três diferentes visões, a saber: segundo abordagem internacional; segundo o IBGC; e à luz da CVM.

O IBGC em seu Código Brasileiro das Melhores Práticas de Governança Corporativa de 2003 (a primeira versão data de 1999) define governança corporativa como sendo:

[...] um sistema pelo qual as sociedades são dirigidas e monitoradas, envolvendo os relacionamentos entre Acionistas/Cotistas, Conselho de Administração, Diretoria, Auditoria Independente e Conselho Fiscal. As boas práticas de governança corporativa têm a finalidade de aumentar o valor da sociedade, facilitar se acesso ao capital e contribuir para a sua perenidade.

Ainda na definição do IBGC a governança corporativa é norteada por quatro princípios básicos, a saber:

- Transparência - definida como o "desejo de informar”, ou seja, a comunicação deve ser rápida, franca e espontânea e não deve se restringir ao desempenho econômicofinanceiro, mas deve considerar todos os demais fatores que norteiam a administração e podem criar valor;

- Eqüidade - é o tratamento justo e igualitário de todos os grupos minoritários, que podem ser colaboradores, clientes, fornecedores ou credores;

- Prestação de Contas (Accountability) - os agentes de governança corporativa devem prestar contas de sua atuação a quem os elegeu e respondem integralmente por todos os atos que praticarem em sua função;

- Responsabilidade Corporativa - trata-se de uma visão ampla da estratégia empresarial, contemplando todos os relacionamentos com a comunidade e deve incluir a criação de riquezas e de oportunidades de emprego, qualificação e diversidade da força de trabalho, estímulo ao desenvolvimento científico por intermédio de tecnologia, e melhoria da

\footnotetext{
${ }^{2}$ Qualquer pessoa ou grupo que tenha investimento, ações ou algum interesse na empresa (Collin, 1998).
} 
qualidade de vida por meio de ações educativas, culturais, assistenciais e de defesa do meio ambiente.

O código do IBGC está dividido em seis capítulos ou seções considerados essenciais para a boa prática de governança corporativa: propriedade (sócios); conselho de administração; gestão; auditoria independente; conselho fiscal; conduta e conflito de interesses.

Ao citar gestão como sendo um dos elementos de boas práticas, verifica-se, portanto, que o sistema de controles internos está contido dentro da estrutura de governança corporativa, assim como a existência e o funcionamento de um conselho fiscal, de um comitê de auditoria e o desenvolvimento dos trabalhos do auditor independente.

A governança emanada pela CVM (2002) distribuiu-se em questões sobre assembléias, estrutura acionária, proteção a minoritários, conselho de administração e fiscal e auditoria independente. Embora sejam recomendações e, por conseguinte, seu descumprimento não é passível de punição, não adotá-las ensejaria explicações.

Nos tópicos seguintes, serão detalhados o conselho de administração, o comitê de auditoria, a auditoria independente e o conselho fiscal, iniciando-se por este último por ser o ponto central desta tese.

\subsection{Conselho Fiscal}

A concepção de um organismo fiscalizador dos negócios sociais já existia desde os primeiros momentos de criação das companhias holandesas (VALVERDE, 1959), nas quais aparecem os primeiros sinais identificadores do que viria a ser a sociedade por ações. O título de participação recebeu o nome de ação, aktie actio, significando o direito dos sócios sobre os lucros e sobre sua cota do patrimônio comum, e as sociedades constituíram-se por força de um privilégio, oktroi charte, (BORGES; LAMY FILHO e PEDREIRA, apud SILVA, 2000, p. 28). Ainda sobre o estudo das companhias, Lamy (1996, p. 87) bem sintetiza: 
Ao se fazer o inventário dos elementos que a constituem, verificar-se-á que têm origem em todas as nações: o Conselho Fiscal é de origem holandesa, a assembléia geral dos acionistas dotados do direito de voto é invenção inglesa e francesa, a resistência contra a maioria começou a manifestarse na Inglaterra, que foi também a primeira, parece, a conferir à minoria o direito de convocar a Assembléia Geral. Foi na Holanda onde primeiro surgiu a idéia de um capital social fixo, e também da Holanda é o estabelecimento do exercício social em um ano. A ação ao portador negociável nasceu na França.

Foi com o código francês de 1807 que se estabeleceram as linhas gerais da sociedade mercantil, e embora não tratando do conselho fiscal, inspirou toda a legislação posterior regulamentadora das sociedades (SILVA, 2000, p. 31). Consoante Valverde (1959), a primeira lei a tornar obrigatório o conselho fiscal foi a lei francesa de 1867, inspirada na legislação anterior representada pelo referido código (Código de Napoleão), seguida de várias legislações em outros países, todas emolduradas por diferentes sistemas.

Ainda hoje o sistema de fiscalização adotado na França é considerado pela doutrina corrente como o mais aperfeiçoado (SILVA, 2000, p. 156). Mantendo-se a tradição, no direito francês a fiscalização das companhias é obrigatoriamente exercida por um ou vários comissaires aux comptes, profissionais que atuam individualmente ou por intermédio de sociedades de profissionais, inscritos na Ordem dos Peritos Contábeis e são nomeados por assembléia geral (CARVALHOSA e LATORRACA, 1997, p. 362).

$\mathrm{Na}$ Espanha, não existe conselho fiscal permanente, embora esteja prevista em lei a nomeação de certos acionistas para examinar as contas, devendo examinar o balanço, a conta de lucros e perdas, a proposta relativa à distribuição de dividendos, podendo ser assessorados por especialistas. Conforme citação de Lacerda (1967, p. 187), os comissionários são indicados pela própria administração, o que resulta numa certa dependência entre comissionários e controladores.

Silva (2000, p. 158) indica que na Itália o conselho fiscal é composto de três a cinco membros efetivos, escolhidos entre acionistas ou não para exercer o controle da administração da sociedade, cabendo-lhe vigiar sobre a observância da lei, dos atos constitutivos, examinar o balanço e a escrituração contábil. Já em Portugal há uma convivência entre dois órgãos semelhantes: o conselho fiscal e o revisor de contas, sendo este último composto por pessoas físicas ou jurídicas especialmente qualificadas e devidamente inscritas em registro especial, obedecendo a regimento profissional que visa a garantir sua idoneidade e independência. 
Também segundo Silva (2000, p. 159), na Argentina, comparativamente ao conselho fiscal, a lei prevê a possibilidade de um síndico único ou de uma sindicatura colegiada, sendo que o síndico deve ser advogado ou contador público ou sociedade civil com responsabilidade solidária constituídas exclusivamente por estes profissionais.

Diferentemente dos demais países aqui descritos, os Estados Unidos e a Inglaterra adotam a fiscalização externa e não têm nem na lei e tampouco nos estatutos a presença dos conselhos fiscais. Nos Estados Unidos, a SEC exerce o controle fiscalizatório sobre as companhias abertas e as empresas de auditoria externa. Silva (2000, p. 162) defende que a fiscalização externa não se reveste do caráter político e institucional de que está revestido o conselho fiscal, não tendo por atribuição proteger a minoria acionária e nem podendo interferir nos destinos da companhia.

O Conselho Fiscal tem atribuição e poder opinativos. A auditoria confere para demonstrar em seu parecer se está certo ou se está errado o procedimento. A conclusão que se permite é a de que este sistema legal não quis adotar o modelo criado pelas demais legislações, que adotaram o corpo coletivo de fiscalização de inspiração francesa.

No Brasil, o conselho fiscal é um órgão de existência obrigatória, mas de funcionamento não permanente, que tem como função fiscalizar os atos da administração, opinar sobre determinadas questões e posicionar os acionistas. Referido conselho já estava previsto na Lei n. ${ }^{\circ} 6.404$ de 1976, em seu artigo n..$^{\circ} 161$, e foi ratificado também no novo Código Civil, em seu artigo n. ${ }^{\circ}$ 1.066. Sendo que as deliberações tanto da lei quanto do código são muito parecidas e/ou complementares.

Mesmo com o advento da Lei n. ${ }^{\circ}$ 11.638, em 28 de dezembro de 2007, a qual prevê alterações à Lei n. ${ }^{0} 6.404$ em vários itens, não houve modificações quanto ao conselho fiscal e suas atribuições.

Assim, tanto a Lei n. ${ }^{\circ}$ 6.404/76, ou a nova Lei n. ${ }^{\circ} 11.638$, quanto o novo Código civil estabelecem que quando instalado o conselho fiscal, este deve ser constituído por no mínimo três e no máximo cinco representantes, com igual número de suplentes. Quando o conselho fiscal não for permanente, este será instalado pela assembléia geral a pedido de acionistas que representem, no mínimo, um décimo das ações com direito a voto, ou cinco por cento das 
ações sem direito a voto, sendo que cada período de funcionamento terminará na primeira assembléia geral ordinária após a sua instalação.

Verifica-se, assim, a divisão na sociedade anônima entre dois grupos: os majoritários ou controladores e os minoritários ou não controladores. A respeito disso e do relacionamento do conselho fiscal, Silva (2000, p. 38) assim se pronuncia:

\begin{abstract}
Considere-se que, por imperativos da lógica mais elementar, o grupo dos majoritários ou dos controladores do capital social é que ocupará os postos de mando da administração dos negócios sociais. Em bom português, os controladores assumirão as rédeas do negócio. Por isso é que o interesse na fiscalização, também por imperativo da lógica elementar, haverá de ser dos acionistas minoritários ou não controladores, exatamente porque não são eles, em regra, os administradores. Em síntese: quem administra não fiscaliza e quem fiscaliza não administra.
\end{abstract}

O conselho fiscal não deve ser entendido como apenas um órgão revisor de contas, mas como instrumento de controle e de informação (SILVA, 2000, p. 85). Ao conselho fiscal compete minimamente:

- Fiscalizar os atos dos administradores e verificar o cumprimento dos seus deveres legais e estatutários;

- Opinar sobre o relatório anual da administração, fazendo constar do seu parecer as informações complementares que julgar necessárias ou úteis à deliberação da assembléia-geral;

- Opinar sobre as propostas dos órgãos da administração, a serem submetidas à assembléia-geral, relativas a modificação do capital social, emissão de debêntures ou bônus de subscrição, planos de investimento ou orçamentos de capital, distribuição de dividendos, transformação, incorporação, fusão ou cisão;

- Denunciar aos órgãos de administração ou à assembléia-geral, os erros, fraudes ou crimes que descobrirem, e sugerir providências úteis à companhia;

- Convocar a assembléia-geral ordinária, se os órgãos da administração retardarem por mais de um mês essa convocação, e a extraordinária, sempre que ocorrerem motivos graves ou urgentes, incluindo na agenda das assembléias as matérias que considerarem necessárias;

- Analisar, ao menos trimestralmente, o balancete e demais demonstrações financeiras elaboradas periodicamente pela companhia; 
- Examinar e opinar sobre as demonstrações financeiras do exercício social.

Em resumo, o conselho fiscal fiscaliza os atos dos administradores, bem como do conselho de administração, e oferece sua opinião quanto aos demonstrativos financeiros examinados pelo auditor externo e, para tanto, pode utilizar-se do auxílio do auditor externo ou de outros especialistas a serem solicitados pelos conselheiros e pagos pela empresa.

Conforme mencionado anteriormente, poucas pesquisas empíricas foram realizadas tendo como problema de estudo o conselho fiscal e práticas de governança corporativa. Nesse contexto, cita-se a dissertação de Escuder (2006) que estudou a percepção dos conselheiros fiscais das empresas listadas na Bovespa classificadas nos níveis 1 e 2 e no novo mercado quanto ao uso das boas práticas de governança corporativa recomendadas pelo guia de orientação às melhores práticas de governança corporativa criado pelo IBGC. Como conclusão da pesquisa, verificou-se que de forma geral e na visão dos conselheiros fiscais, as empresas buscam adequarem-se às práticas recomendadas, mas não exatamente em todas as recomendações.

Importante salientar que nas sociedades de economia mista ${ }^{3}$ o funcionamento do conselho fiscal é permanente uma vez que existem grupos de acionistas com interesses distintos, como o Estado, que busca o interesse público, e o investidor de capital privado, que visa ao lucro. A função dos conselheiros fiscais, assim, é verificar a estrita legalidade da conduta e dos atos dos administradores na condução daquela, que deve visar, em primeiro lugar, ao atendimento dos interesses da coletividade.

Nos Conselhos Fiscais destas entidades dois de seus membros e respectivos suplentes serão escolhidos pelos minoritários, um pelos possuidores de ações ordinárias e outro pelos de ações preferenciais. O órgão fiscal funcionará de qualquer forma, tenham ou não os acionistas minoritários e preferencialistas, se houver, indicados seus representantes no órgão. Isso ocorre porque o controle interno nessas entidades é fundamental, dada a impessoalidade do ente público que a controla e dos agentes públicos que a administram (CARVALHOSA, 2003).

\footnotetext{
${ }^{3}$ Empresas cuja maioria simples do capital pertence ao poder público, sua constituição depende de prévia
} autorização legislativa. 


\subsection{Conselho de Administração}

O artigo n. ${ }^{\circ} 138$ da Lei n. ${ }^{\circ}$ 6.404/76 determina que o conselho de administração é um órgão obrigatório para as companhias abertas e de capital autorizado. Estabelece, também, em seu artigo n. $^{\circ}$ 140, que será composto por, no mínimo, três membros eleitos pela assembléia geral e que podem ser por ela destituídos, ficando a cargo do estatuto da empresa a definição do número exato de membros, ou seu número mínimo e máximo.

O cargo de membro do conselho de administração é privativo de acionistas (Lei n. ${ }^{\circ}$ 6.404, art. 146), sendo que em sua constituição existem representantes dos proprietários controladores e minoritários, conselheiros externos independentes e representantes de outras partes interessadas previstas no estatuto (Lei n. ${ }^{\circ}$ 6.404, art. 140). As principais atribuições do conselho são:

- Fixar a orientação geral dos negócios;

- $\quad$ Eleger e destituir os diretores e fixar-lhes as atribuições;

- $\quad$ Fiscalizar a gestão dos diretores;

- Examinar, a qualquer tempo, os livros e papéis da companhia;

- Manifestar-se sobre o relatório da administração e as contas da diretoria;

- Manifestar-se previamente sobre atos ou contratos, quando o estatuto assim o exigir;

- $\quad$ Escolher e destituir os auditores independentes.

$\mathrm{Na}$ lei brasileira não existe menção sobre a necessidade de separação de funções entre o presidente do conselho de administração e o principal executivo (CEO) da empresa, sendo possível, assim, o acúmulo das duas funções. Ressalta-se que em muitos países utiliza-se o conceito de separação de funções, que conforme relatam Coombes e Wong (2004, p. 2):

[...] constitui um componente indispensável da independência do conselho de administração. [...] O executivo-chefe administra a empresa. O presidente do conselho de administração conduz um colegiado que tem entre suas funções essenciais a de monitorar adequadamente o executivo-chefe e avaliar seu desempenho. Se as duas funções são exercidas pela mesma pessoa, fica mais difícil para o conselho de administração exprimir opiniões independentes e examinar questões sob diferentes perspectivas $[\ldots]$. 
Ainda sobre a separação de funções, Yermack (1996) verificou alta correlação positiva entre a valorização das empresas e a separação de funções entre o presidente do conselho de administração e o principal executivo. Brown e Caylor (2006), por sua vez, demonstraram que o valor de mercado das empresas é maior quando referidas funções são ocupadas por pessoas distintas.

Pesquisas internacionais também já foram realizadas relacionando o conselho de administração e gerenciamento de resultados. Xie et al (2001), por exemplo, examinaram o papel do conselho, do comitê de auditoria e do comitê executivo na prevenção de earnings management e verificaram que conselhos e comitês compostos de especialistas com conhecimentos financeiros estão associados com menores níveis de gerenciamento de resultados. Bradbury et al (2002) evidenciaram que o tamanho do conselho de administração e um comitê de auditoria independente também estão relacionados com informações contábeis de melhor qualidade (ou com menores níveis de gerenciamento de resultados).

Embora o objetivo central desta tese seja o conselho fiscal, com o intuito de verificar se as conclusões encontradas nas pesquisas externas sobre gerenciamento de resultados e o conselho de administração seriam similares se aplicadas ao Brasil, no capítulo cinco será realizado teste estatístico utilizando o conselho de administração como uma das variáveis de governança corporativa conforme aplicado nas pesquisas citadas acima.

\subsection{Comitê de Auditoria}

A criação de comitês nas empresas voltados a controlar as diversas áreas de atuação dos negócios é um dos pilares da governança corporativa. Devido a sua responsabilidade na qualidade das informações econômicas e financeiras refletidas nas demonstrações contábeis uma das áreas de atuação mais importante é a Auditoria (NETO, 2007, p. 40).

As companhias abertas brasileiras com emissões negociadas nos Estados Unidos tiveram que constituir, por determinação da Lei Sarbanes-Oxley (SOX), seção 301, um comitê de auditoria, que tem como responsabilidade a contratação, supervisão e substituição dos auditores independentes. Ademais, também são de responsabilidade deste órgão a análise das 
demonstrações financeiras, a supervisão da área financeira e garantia de que a administração desenvolva controles internos confiáveis.

Citado comitê deve ser composto de no mínimo três integrantes, independentes do corpo de diretores, e os quais não podem prestar qualquer tipo de serviço de consultoria à companhia ou partes relacionadas. Também deverão fazer parte do conselho de administração e possuir bons conhecimentos a respeito dos negócios da empresa, de princípios e práticas contábeis, de sistemas de controles internos e, ao menos um dos integrantes deve ser especialista em finanças.

Com relação aos conhecimentos exigidos dos membros do comitê de auditoria, importante ressaltar o trabalho desenvolvido pelo Blue Ribbon Committee on Improving the Effectiveness of Corporate Audit Committees estabelecido em conjunto com a NYSE, New York Stock Exchange, e a NASD, National Association of Securities Dealers, com o intuito de fazer recomendações às corporações quanto à composição e funcionamento dos comitês de auditoria, trabalho este posteriormente adotado pela SEC. O relatório do Blue Ribbon Committee foi apresentado em fevereiro de 1999, perfazendo um total de dez recomendações versando sobre requerimentos, estrutura, funcionamento e comunicação com os auditores externos e com a alta administração.

Em maio de 2004, o Conselho Monetário Nacional, por meio do BACEN, publicou a Resolução CMN n. ${ }^{\circ}$ 3.198, que, entre outras disposições, determinou a criação de comitê de auditoria para as instituições financeiras com patrimônio líquido de referência superior a $R \$ 1$ bilhão. Também versando sobre a criação de comitê de auditoria, em dezembro de 2004, o Conselho Nacional de Seguros Privados, por meio da SUSEP, emitiu a Resolução CNSP no 118.

Ambas as disposições são muito parecidas com as impostas pela SOX com relação ao comitê de auditoria, entretanto, as resoluções são mais específicas quanto à formação do integrante especialista, mencionando que este deve possuir conhecimentos nas áreas de contabilidade e auditoria. Ademais, não estabelece a obrigatoriedade dos membros do comitê serem também integrantes do conselho de administração. 
As principais atribuições do comitê de auditoria pela Resolução CMN n. 3.198 e pela Resolução CNSP nº 118 são:

- Estabelecer as regras operacionais para seu próprio funcionamento, as quais devem ser aprovadas pelo conselho de administração ou pela diretoria da instituição, sendo que citadas regras devem estar à disposição dos acionistas;

- Recomendar à administração a empresa de auditoria independente a ser contratada, bem como sua substituição quando necessário;

- Revisar as demonstrações contábeis semestrais, relatórios da administração e parecer do auditor independente;

- Avaliar a efetividade das auditorias interna e externa, inclusive quanto à verificação do cumprimento de dispositivos legais;

- Avaliar o cumprimento das recomendações dos auditores independentes pela administração;

- $\quad$ Estabelecer e divulgar procedimentos para recepção e tratamento de informações acerca de descumprimentos legais, inclusive pela proteção do prestador e da confidencialidade da informação;

- $\quad$ Recomendar à administração a correção ou aprimoramento de políticas e procedimentos identificados;

- Reunir-se, no mínimo trimestralmente, com a diretoria da instituição, com as auditorias externa e interna para verificar o cumprimento de suas recomendações;

- Reunir-se com o conselho fiscal e conselho de administração, por solicitação destes, para discutir acerca de políticas, práticas e procedimentos identificados.

Verifica-se que, em algumas ocasiões, as competências do conselho fiscal e do comitê de auditoria se confundem ou mesmo se sobrepõem, principalmente quanto ao poder de fiscalização. Assim, é muito importante que os dois órgãos planejem ou se comuniquem constantemente sobre os trabalhos desenvolvidos, para a obtenção de sinergia e melhores resultados para a empresa.

A constituição do comitê de auditoria ensejou a realização de algumas pesquisas que têm tentado verificar a existência de relacionamento do comitê de auditoria com a qualidade dos 
relatórios financeiros. Wild (1996), por exemplo, verificou que a reação do mercado para os ganhos distribuídos e reportados subseqüentemente à formação do comitê de auditoria é maior do que em períodos anteriores.

Ainda no intuito de verificar a qualidade dos relatórios divulgados e seu relacionamento com o comitê de auditoria, Abbott et al (2002) estudaram o impacto de certas características do comitê de auditoria sugeridas pelo Blue Ribbon Committee e a probabilidade de relatórios financeiros divulgados com erros. Os resultados da pesquisa indicaram que comitês com membros independentes e que realizam reuniões no mínimo quatro vezes ao ano são significante e negativamente associados a relatórios que apresentam erros ou fraudes.

Liu (2005), por sua vez, estabeleceu como hipótese para sua pesquisa que a formação de um comitê de auditoria com membros independentes e com ao menos um integrante sendo especialista financeiro traria melhorias na divulgação dos relatórios financeiros. $\mathrm{O}$ resultado para sua pesquisa, a partir das variáveis e critérios estabelecidos, foi confirmado, sendo que o maior impacto na melhoria visualizada está relacionado com a independência dos membros do comitê.

Dionne e Triki (2005) também investigaram o efeito da independência do comitê de auditoria e os conhecimentos contábeis de seus membros relacionando-os ao gerenciamento de riscos de trinta e seis empresas norte-americanas, obtendo como resultado que o tamanho do comitê de auditoria e membros independentes é benéfico para os acionistas, contudo, que o conhecimento contábil poderia não ser necessário.

No Brasil, pelo fato de sua constituição não ser obrigatória, apenas para algumas empresas financeiras, esta tese não pretende estudar em detalhes a relação entre sua constituição e o relacionamento com níveis menores de gerenciamento de resultado. Ademais, dadas as diferenças existentes entre o comitê de auditoria e o conselho fiscal, e sendo este último o tema central deste trabalho, seu relacionamento será verificado em maiores detalhes. 


\subsection{Auditor Independente}

O código do IBGC sugere que toda empresa preocupada com a governança corporativa deve contar com os serviços de auditoria independente para atestar que as demonstrações financeiras refletem adequadamente a realidade da sociedade.

Ao divulgar seu parecer sobre as demonstrações financeiras, o auditor expressa suas conclusões sobre a empresa e, para tanto, teve que verificar fatores de ordem técnica, ética e legal, ou seja, a contribuição do auditor independente para atestar a qualidade dos controles internos é fundamental.

Almeida (1996, p. 51) declara que os controles contábeis são essenciais na verificação do auditor, mas que, evidentemente, qualquer controle administrativo também deve ser verificado se assim se fizer necessário, o que deixa claro a extensão dos trabalhos de auditoria em toda a organização.

Dada a importância do trabalho de auditoria independente para atestar aos acionistas e demais interessados, tais como fornecedores, analistas, funcionários, a veracidade das informações prestadas à sociedade, vários órgãos reguladores impuseram algumas regras para manter a sua independência e, por outro lado, manter a qualidade dos serviços desenvolvidos.

A respeito disso, a Lei Sarbanes-Oxley determinou e estabeleceu, por meio do PCAOB, alguns serviços que não podem ser desenvolvidos pela auditoria independente evitando-se, assim, a dependência da empresa auditada, tais como:

- $\quad$ Serviços de contabilidade;

- $\quad$ Desenho e implantação do sistema financeiro interno;

- $\quad$ Serviços de avaliação ou valorização de ativos e passivos;

- Serviços atuariais;

- $\quad$ Terceirização de auditoria interna;

- Serviços de gerenciamento e de recursos humanos;

- $\quad$ Consultoria em investimentos;

- Consultoria em empréstimos bancários entre outros que possam ferir a independência. 
Outra regra imposta pelo PCAOB e já relatada anteriormente foi que a contratação da empresa de auditoria independente deve ser realizada pelo comitê de auditoria e qualquer outro serviço, relacionado ou não à auditoria, também deve ser aprovado por este comitê.

Contudo, ressalta-se que pelas normas brasileiras a escolha da auditoria independente é de competência exclusiva do conselho de administração, assim, na busca de atendimento a ambas às normas, as empresas brasileiras estabeleceram a indicação da auditoria independente pelo comitê de auditoria, ou pelo conselho fiscal ${ }^{4}$, ao conselho de administração.

A SOX também determinou que o sócio principal encarregado pelos trabalhos de auditoria e o sócio responsável pela revisão sejam substituídos a cada cinco anos, estabelecendo-se dessa forma um rodízio de sócios.

Referindo-se à citada substituição do sócio-auditor, no Brasil, a Resolução CMN n. ${ }^{\circ} 3.198$ determinava a substituição da empresa de auditoria a cada cinco anos para as instituições financeiras, da mesma forma que a CVM, Comissão de Valores Mobiliários, por meio da

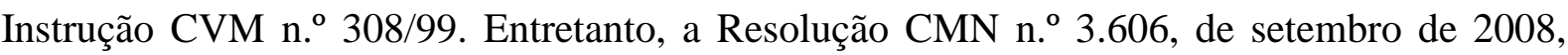
suspendeu a substituição da empresa de auditoria pela substituição dos diretores, gerentes e supervisores que prestam serviços às empresas, enquanto a CVM manteve inalterada sua instrução. Salienta-se que por meio da Deliberação n. ${ }^{\circ}$ 549/08, a CVM permitiu, exclusivamente às companhias abertas, manterem seus auditores independentes atuais até o encerramento do exercício social de 2011. Cabe ressaltar sobre esse tema, o trabalho de Oliveira (2005) o qual por meio de pesquisa qualitativa e questionário respondido por executivos concluiu que o rodízio das empresas de auditoria independente não diminuiu o risco de fraude, tampouco a independência do auditor.

\footnotetext{
4 A Lei Sarbanes Oxley impôs novas regras de governança corporativa que foram estendidas pela SEC às companhias estrangeiras com emissões negociadas nos Estados Unidos, propiciando a inter-relação entre ordenamentos jurídicos distintos (atribuição de função ao comitê de auditoria que na lei brasileira pertence a outro órgão). FREITAS (apud ALMEIDA e ROSSETTI, 2006, p. 433) esclarece que “[...] Há, para tanto, procedimentos previstos no Direito Internacional Privado de reenvio e recepção para solucionar conflitos de normas no mesmo espaço. No caso brasileiro, por exemplo, isto se deu para permitir a adaptação das exigências de criação do Comitê de Auditoria, que conflitavam com os do Conselho Fiscal previsto na nossa legislação. Após manifestação da CVM à SEC, o Conselho Fiscal foi aceito como instituição que cumpria a finalidade desejada, desde que com adaptações: criou-se assim o chamado Conselho Fiscal "Turbinado"”.
} 
Importante ressaltar que o auditor independente deve reportar ao comitê de auditoria ou ao conselho de administração pontos relacionados às principais políticas contábeis, deficiências e/ou falhas significativas nos controles internos, tratamentos contábeis adotados, avaliação de riscos e análise de possibilidade de fraudes.

\subsection{Níveis Diferenciados de Governança Corporativa e Novo Mercado}

Em dezembro de 2000, a BOVESPA, Bolsa de Valores do Estado de São Paulo, implantou segmentos especiais de listagem com o intuito de proporcionar um ambiente de negociação que estimulasse tanto o interesse dos investidores quanto a valorização das companhias.

Referidos segmentos, o "Novo Mercado" e os "Níveis Diferenciados de Governança Corporativa 1 e 2", estipulam compromissos de transparência adicionais aos existentes na legislação atual e referem-se à prestação de informações que facilitam o acompanhamento e a fiscalização dos atos dos administradores e controladores.

Segundo a BOVESPA (2006) a premissa básica para a constituição desses segmentos é que a melhoria da qualidade das informações, bem como a ampliação dos direitos societários, reduzem as incertezas e os riscos, elevando-se a disposição dos investidores na aquisição de ações.

Na realidade, a criação desses segmentos pela BOVESPA apenas reforçou a necessidade e o desenvolvimento da governança corporativa pelas empresas de capital aberto, pois, em suma, os relatórios exigidos já eram obrigatórios pela regra legal. Consoante Lima et al (2002, p. 05):

[...] esses relatórios são os mesmos que as companhias eram obrigadas a divulgar mesmo antes do surgimento dos níveis diferenciados de governança; sendo assim, a mudança se encontra principalmente no aprofundamento e detalhamento da evidenciação de tais informações. Isto explica, em parte, o fato de algumas companhias, principalmente, as Blue Chips ${ }^{5}$, que já se propiciavam de tal nível de transparência, terem aderido ao nível 1 já em seu primeiro mês de existência (junho de 2001).

${ }^{5}$ Blue Chips representam ações de baixo risco de empresas consideradas "boas" e que possuem um bom histórico de distribuição de dividendos (Collin, 1998, p. 25). 
Destaca-se que mesmo que as empresas atendam todos os requisitos, sejam do Nível 1, Nível 2 ou Novo Mercado, o registro em qualquer um dos segmentos não é automático, sendo necessária a assinatura de contrato celebrado entre a BOVESPA, a companhia, os administradores e o acionista controlador.

Entretanto, a partir de 2002, com a publicação da Resolução n. ${ }^{\circ}$ 282/02-CA, as empresas que desejarem obter registro na BOVESPA para distribuição pública, primária ou secundária de ações, debêntures conversíveis em ações ou bônus de subscrição de emissão da companhia junto à CVM - Comissão de Valores Mobiliários - deverão aderir, no mínimo, ao Nível 1 das Práticas Diferenciadas de Governança Corporativa.

\subsubsection{Nível Diferenciado 1}

Além de não poderem ter partes beneficiárias, as companhias que aderem ao Nível 1 de governança corporativa, basicamente assumem compromissos relacionados à prestação de informações perante os investidores, tais como:

- Demonstrações financeiras consolidadas e fluxos de caixa;

- Relatório de revisão especial emitido por auditor independente;

- Divulgação de calendário anual com os eventos corporativos;

- Divulgação mensal de quaisquer negociações de valores mobiliários de emissão da companhia e de seus derivativos.

\subsubsection{Nível Diferenciado 2}

A adesão ao Nível 2 exige os mesmos compromissos do Nível 1 com algumas adições:

- $\quad$ Elaboração de demonstrações financeiras anuais em USGAAP ou IFRS;

- Concessão de direito a voto para os detentores de ações preferenciais em algumas situações, tais como: transformação, incorporação, fusão ou cisão; aprovação de contratos entre a companhia e o seu controlador; avaliação de bens para aumento de capital;

- $\quad$ Realização de oferta pública de aquisição das ações em circulação, no mínimo, pelo valor econômico da companhia no caso de fechamento de capital ou cancelamento do contrato Nível 2; 
- Composição do Conselho de Administração com, no mínimo, cinco membros e mandato de no máximo dois anos;

- Extensão do mesmo tratamento dado ao controlador vendedor pelo comprador, no caso de venda, aos acionistas detentores de ações ordinárias e pagamento de, no mínimo, $80 \%$ do valor pago às ações ordinárias para os detentores de ações preferenciais.

\subsubsection{Novo Mercado}

Os requisitos para adesão ao Novo Mercado são os mesmos que os exigidos no Nível 2, estando a principal diferença relacionada à emissão de ações preferenciais: no primeiro só existem ações ordinárias e, neste último, existem ações preferenciais.

Dessa forma, o Novo Mercado é indicado para empresas que desejam abrir o capital, e o Nível 2 é direcionado para empresas que já possuem ações preferenciais negociadas na bolsa de valores e não tem condições tempestivas de convertê-las em ações ordinárias. 


\section{SISTEMA DE CONTROLES INTERNOS}

\subsection{Definições de controles internos}

Martins (2003, p. 305) de forma simples define que controlar é "conhecer a realidade, compará-la com o que deveria ser, tomar conhecimento rápido das divergências e suas origens e tomar atitudes para sua correção. [...] Esse mesmo conceito é o aplicável a qualquer setor ou atividade de uma empresa." É possível inferir pela citação que a função de controle é bastante abrangente, uma vez que é necessário conhecer a realidade, ou seja, como os processos, atividades, planejamento estratégico, enfim, como o todo dentro de uma organização está estruturado, saber analisá-los para verificar se estão como deveriam e, ainda, agir dentro de um limite de tempo adequado para eventuais correções.

Catelli (2001, p. 146), ainda que se referisse à mensuração de resultado e desempenho utilizados pela controladoria, demonstra a amplitude do controle e a necessidade de sua execução em todos os âmbitos da empresa:

\footnotetext{
O controle deve ser executado nas áreas operacionais, na administração das áreas operacionais e na empresa em sua totalidade: avaliação de desempenho global e analítica. Para que seja implantado com sucesso, o controle envolve quatro etapas:

1. prever os resultados das decisões na forma de medidas de desempenho;

2. reunir informações sobre o desempenho real;

3. comparar o desempenho real com o previsto; e

4. verificar quando uma decisão foi deficiente e corrigir o procedimento que a produziu e suas conseqüências, quando possível.
}

Contudo, o controle não deve ser entendido apenas como o processo de mensuração de resultado e desempenho, mas também como o monitoramente das ações dos gestores decorrentes do poder exercido por estes dentro das organizações, bem como de toda a estrutura organizacional. Besta (apud MOSIMANN e FISCH, 1999, p. 70) bem define essa função:

[...] se todo aquele que tem ação direta ou indireta na administração de uma azienda tivesse honestidade plena, memória perfeita e inteligência suficiente para saber, em qualquer momento, que coisa lhe competia fazer em benefício daquela, e se não houvesse necessidade de estímulos para a ação, ou de freios para nada fazer em excesso, a administração poderia desenvolver-se sem o controle. 
O AICPA, por meio do SAS, Statements on Auditing Standards, 55, de 1988 e do SAS 78, de 1995, assim se posicionou sobre controles internos:

Controle interno é um processo, estabelecido pelo conselho de administração, diretoria, gerência ou outras pessoas da companhia, estruturado para providenciar razoável segurança de que os seguintes objetivos sejam atingidos:

1. confiabilidade nos relatórios financeiros;

2. eficácia e eficiência das operações, e conformidade com as leis e normas aplicáveis.

Logo, um sistema de controles internos deve abranger toda a organização e trazer razoável confiança de que os sistemas contábeis são adequados, que as atividades e/ou processos estão sendo monitorados, tudo em conformidade com as normas internas e externas que regem determinada organização.

Ainda relacionando controles internos com a confiabilidade dos relatórios financeiros, principalmente em decorrência à Lei Sarbanes Oxley, em 2003 a SEC definiu controles internos como sendo:

\footnotetext{
Um processo desenhado pelo, ou sob a supervisão do presidente e do diretor financeiro, ou pessoas desempenhando funções similares, aplicados pela diretoria da empresa, gerência e outras pessoas, para proporcionar razoável segurança sobre a confiabilidade dos relatórios financeiros e a preparação de demonstrações contábeis para fins externos, de acordo com os princípios contábeis geralmente aceitos e inclui políticas e procedimentos que:

1. providenciem a manutenção de registros que, em razoável detalhamento, reflitam correta e adequadamente as transações e as posições dos ativos da companhia;

2. providenciem razoável segurança de que as transações estão registradas como necessário para permitir a preparação de demonstrações contábeis de acordo com os princípios contábeis geralmente aceitos, e que as receitas e despesas da companhia estão sendo reconhecidas somente de acordo com autorizações dos gerentes e diretores da companhia;

3. providenciem razoável segurança relacionada à prevenção ou tempestiva detecção de aquisições, uso ou disposição de ativos da companhia de forma não autorizada e que possam proporcionar efeitos materiais nas demonstrações contábeis.
}

No Brasil, o CFC, Conselho Federal de Contabilidade, por meio de sua Resolução $n^{\circ}$ 820, de dezembro de 1997, definiu controles internos em conjunto com sistema contábil estabelecendo que ambos “[...] compreendem o plano de organização e o conjunto integrado de método e procedimentos adotados pela entidade na proteção do seu patrimônio, promoção da confiabilidade e tempestividade dos seus registros e demonstrações contábeis, e da sua eficácia operacional”. 
Em resumo, um sistema de controles internos deve ser entendido como parte integrante das boas práticas de governança corporativa e, basicamente, subdividido em controle contábil, controle de riscos e conformidade com leis e regulamentações.

A respeito disso, o IBGC, em seu Código das Melhores Práticas de Governança Corporativa enfatiza que é de responsabilidade do principal executivo a criação de sistemas de controle internos que organizem e monitorem um fluxo de informações corretas, reais e completas sejam de natureza financeira, operacional e de obediência às leis, corroborando com a afirmação acima.

\subsection{Controle Contábil}

O principal objetivo da Contabilidade é proporcionar aos usuários, sejam internos ou externos à organização, informações e análises de caráter econômico, financeiro, físico e operacional. Dessa forma, o sistema de informação contábil assegura, ou deveria assegurar, que as transações ocorreram de maneira satisfatória, ou em outras palavras, que aconteceram da forma como deveria ser.

Corroborando a afirmação acima, Lopes e Martins (2005, p. 61) citam que "[...] a contabilidade também impacta os mecanismos de governança corporativa. Em situações nas quais os mecanismos de governança não são eficazes para proteger os investidores, a contabilidade pode agir de forma complementar".

Ademais, considerando os objetivos qualitativos da Contabilidade, é possível ressaltar a importância desta para um sistema de controle interno adequado. Consoante Hendriksen e Breda (1999, p. 96), existem dois itens qualitativos principais na Contabilidade: relevância e confiabilidade. A relevância pode ser entendida como a informação pertinente à questão em análise, ou seja, a informação que faz a diferença numa tomada de decisão. Já a confiabilidade, de forma geral, garante que a informação seja livre de erro e represente fidedignamente o que visa representar. Contudo, para que a informação seja livre de erro, é necessário que todo sistema, ou toda a cadeia de valor da companhia, não contenha viés, que seja confiável. 
A ilustração a seguir demonstra os demais objetivos qualitativos da Contabilidade, percebe-se que é necessário que todo o sistema organizacional esteja funcionando adequadamente para que a Contabilidade desempenhe seu papel.

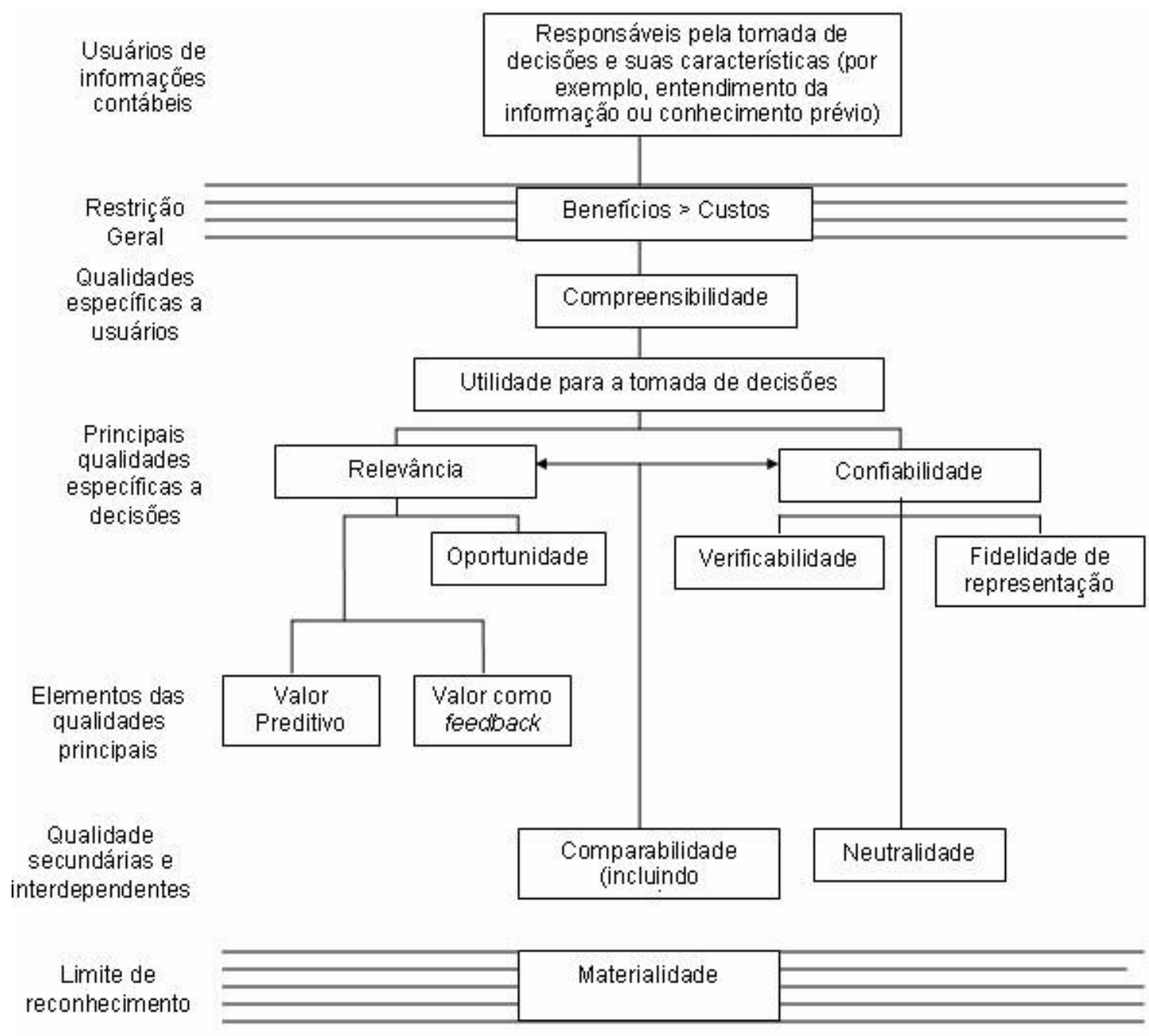

Ilustração 3 - Uma hierarquia de qualidades em contabilidade Fonte: Hendirksen e Breda (1999, p. 96)

Entretanto, em alguns momentos da economia, seja mundial ou nacional, é necessário reforço de alguma autoridade governamental para garantir que contabilmente, e conseqüentemente, administrativamente, a saúde das empresas permanece inalterada e seus sistemas de controles internos funcionando adequadamente. No Brasil, com a crise que vivia o sistema financeiro nacional na década de 1990 e em decorrência da intervenção realizada pelo BACEN (Banco 
Central do Brasil) em vários Bancos, o CMN (Conselho Monetário Nacional) emitiu a Resolução CMN nº 2.554 em setembro de 1998.

Referida resolução determinou que todas as instituições financeiras desenvolvessem e implantassem controles internos que pudessem responder pela conformidade de todas as atividades realizadas e pelos sistemas de informações financeiras, operacionais e gerenciais, além de assegurar o cumprimento das normas. Ressaltou, também, ser de responsabilidade da diretoria da instituição a implantação desses controles e a adoção de procedimentos que garantissem o cumprimento sistemático da citada resolução. Dentre as principais premissas estabelecidas, destacam-se:

- Os controles internos devem ser acessíveis a todos os funcionários da organização de forma que possam ter ciência das suas respectivas funções e responsabilidades no processo;

- Segregação de atividades com o intuito de se evitar conflito de interesses, bem como se estabelecer formas de minimizar e monitorar áreas identificadas como de potencial conflito;

- Identificação e avaliação de fatores externos que possam afetar adversamente os objetivos da instituição;

- Existência de canais de comunicação que assegurem aos funcionários o acesso a informações confiáveis, tempestivas e compreensíveis consideradas relevantes para suas atividades;

- $\quad$ Avaliação contínua dos diversos riscos que possam afetar a instituição;

- Acompanhamento das atividades de forma a assegurar que os objetivos estão sendo alcançados, dentro dos limites e leis aplicáveis, e que qualquer desvio possa ser corrigido;

- Existência de testes periódicos para os sistemas de informação, principalmente os eletrônicos;

- Revisão constante do sistema de controles internos, de forma que novos riscos possam ser contemplados;

- As atividades de controles internos devem ser objeto de relatórios, no mínimo semestrais, contendo as conclusões dos exames efetuados e a manifestação dos 
responsáveis por possíveis deficientes identificadas e das medidas adotadas para sanálas.

É possível identificar a preocupação da autoridade monetária com o sistema de controles internos voltado para o controle financeiro, operacional e de gestão de riscos. Contudo, a resolução ainda trata de forma genérica a estruturação desse sistema, não entrando em detalhes de quais seriam os requisitos operacionais básicos.

Com o intuito de reforçar a governança no sistema de seguros, previdência complementar aberta e capitalização, a SUSEP (Superintendência de Seguros Privados) emitiu a Circular $n^{\circ}$ 249, em fevereiro de 2004, e a Circular n ${ }^{\circ} 280$, em dezembro de 2004, dispondo, similarmente ao BACEN, sobre a implantação de um sistema de controles internos, bem como sobre os procedimentos mínimos a serem observados quando da elaboração do relatório circunstanciado sobre a adequação dos controles internos.

Também em 2004, o CGPC (Conselho de Gestão da Previdência Complementar) publicou a Resolução CGPC n 13 estabelecendo princípios, regras e práticas de governança, gestão e controles internos para as entidades de previdência complementar fechadas. Verifica-se, assim, a preocupação latente no Brasil para os controles internos e contábeis.

Buscando os mesmos objetivos e em decorrência dos escândalos ocorridos no final do século XX e início do século XXI envolvendo grandes empresas, como Enron, Adelphia Comunications, Kmart, Worldcom, Global Crossing, os Estados Unidos promulgaram a lei Sarbanes-Oxley (SOX) a qual procurou abranger muitos aspectos do ambiente corporativo, fornecendo uma grande ênfase para as severas punições aos administradores e auditores externos em casos de fraudes.

\subsubsection{Lei Sarbanes Oxley (SOX)}

A lei Sarbanes Oxley foi promulgada em 2002 pelo congresso dos Estados Unidos, estabelecendo prazo de adequação às empresas norte-americanas até 31 de dezembro de 2004 . Referida lei está dividida em diversos títulos e seções, desde a criação do PCAOB, Public Company Accounting Oversight Board, órgão responsável pela fiscalização das empresas de 
auditoria externa, que antes eram auto-regulamentadas, passando pelas responsabilidades dos auditores e administradores, divulgação dos relatórios financeiros, fraudes e respectivas punições. No quadro a seguir, estão descritas, resumidamente, as principais diretrizes emanadas pela lei.

Quadro 1 - Lei Sarbanes Oxley - Resumo dos títulos/seções

\begin{tabular}{|c|c|c|}
\hline $\mathbf{N}^{\mathbf{0}}$ Título & Título & Descrição \\
\hline 1 & $\begin{array}{l}\text { PCAOB - Public Company Accounting } \\
\text { Oversight Board }\end{array}$ & $\begin{array}{l}\text { Constitui o PCAOB como uma entidade independente, } \\
\text { sob supervisão da SEC, com o objetivo de } \\
\text { supervisionar os auditores independentes. }\end{array}$ \\
\hline 2 & Auditor Independence & $\begin{array}{l}\text { Estabelece os serviços que podem ser prestados pelos } \\
\text { auditores independentes, evitando-se, assim, conflito de } \\
\text { interesses; } \\
\text { Determina que os auditores independentes sejam } \\
\text { contratados e seus serviços acompanhados por comitê } \\
\text { de auditoria. }\end{array}$ \\
\hline 3 & Corporate Responsibility & $\begin{array}{l}\text { Estabelece a criação do comitê de auditoria que deve } \\
\text { ser composto por no mínimo três integrantes, } \\
\text { independentes da diretoria, integrantes do conselho de } \\
\text { administração e, ao menos um dos integrantes deve ser } \\
\text { especialista em finanças. }\end{array}$ \\
\hline 4 & Enhanced Financial Disclosures & $\begin{array}{l}\text { Determina regras quanto aos empréstimos aos } \\
\text { executivos; } \\
\text { Estabelece que as companhias abertas devam emitir } \\
\text { relatórios anuais contendo a declaração da } \\
\text { administração de que a estrutura de controles internos é } \\
\text { adequada. }\end{array}$ \\
\hline 5 & Analyst Conflicts of Interest & $\begin{array}{l}\text { Proíbe qualquer tipo de remuneração das companhias } \\
\text { para os analistas de mercado. }\end{array}$ \\
\hline 6 & Commission Resources and Authority & $\begin{array}{l}\begin{array}{l}\text { Provê recursos financeiros à SEC e reforça sua } \\
\text { autoridade e poder punitivo. }\end{array} \\
\end{array}$ \\
\hline 7 & Studies and Reports & $\begin{array}{l}\text { Estabelece diversos estudos à SEC: eventuais fusões } \\
\text { entre empresas de auditorias externas; conduta das } \\
\text { agências de "rating"; violações ocorridas no mercado } \\
\text { de capitais norte-americano; tipos e naturezas de } \\
\text { fraudes. }\end{array}$ \\
\hline 8 & $\begin{array}{|lll|}\begin{array}{l}\text { Corporate and Criminal Fraud } \\
\text { Accountability }\end{array} & & \\
\end{array}$ & $\begin{array}{l}\text { Estabelece punições severas contra crimes e fraudes } \\
\text { corporativas. }\end{array}$ \\
\hline 9 & White-Collar Crime Penalty Enhancements & $\begin{array}{l}\text { Estabelece punições mais severas aos diretores das } \\
\text { companhias para algumas fraudes corporativas; } \\
\text { Determina que o presidente e o diretor financeiro } \\
\text { devam assinar e certificar que as demonstrações } \\
\text { contábeis estão de acordo com as regras da SEC. }\end{array}$ \\
\hline 10 & Corporate Tax Returns & $\begin{array}{l}\text { Estabelece a responsabilidade dos presidentes das } \\
\text { companhias pelas declarações de imposto de renda. }\end{array}$ \\
\hline 11 & Corporate Fraud and Accountability & $\begin{array}{l}\text { Determina punições mais severas para crimes } \\
\text { relacionados à preparação e divulgação de relatórios } \\
\text { financeiros, além de tentativas de obstrução. }\end{array}$ \\
\hline
\end{tabular}


O PCAOB é uma comissão independente do governo dos Estados Unidos e sem fins lucrativos que tem a responsabilidade de fiscalizar as empresas de auditoria independente submetidas à regulamentação da SEC. Como pronunciamentos (auditing standard) deste órgão, até dezembro de 2007, tem-se:

- $\quad$ Auditing Standard 1 - References in Auditors' Reports to the Standards of the Public Company Accounting Oversight Board (AS1): faz menção aos pareceres de auditoria utilizados pelos auditores independentes para as demonstrações financeiras e revisões trimestrais;

- Auditing Standard 2 - Na Audit of Internal Control Over Financial Reporting Performed in Conjunction With na Audit of Financial Statements (AS2): estabelece condições e subsídios para que os auditores independentes forneçam opinião sobre as demonstrações financeiras e também sobre a avaliação da administração quanto a seus controles internos. Em julho de 2007, o PCAOB divulgou o AS5 que o substituiu;

- $\quad$ Auditing Standard 3 - Audit Documentation (AS3): estabelece qual o nível de qualidade da documentação das evidências dos trabalhos de auditoria para análise e exames completos das demonstrações financeiras, revisões limitadas e certificações dos processos de controles internos;

- $\quad$ Auditing Standard 4 - Reporting on Whether a Previously Reported Material Weakness Continues to Exist (AS4): estabelece condições e subsídios para que os auditores independentes opinem sobre as demonstrações financeiras de empresas de capital aberto que já tiveram parecer indicando deficiências materiais devido a fraquezas de controle interno.

- $\quad$ Auditing Standard 5 - An Audit of Internal Control Over Financial Reporting That is Integrated With an Audit of Financial Statements (AS5): estabelece condições e subsídios para que os auditores independentes forneçam opinião sobre as demonstrações financeiras e também sobre a avaliação da administração quanto a seus controles internos, contudo, como substituiu o AS2, traz como modificações a possibilidade de a auditoria de controles internos ser integrada com a auditoria das demonstrações financeiras, além de oferecer menos detalhes quanto aos aspectos teóricos de entendimento sobre controles internos. Entretanto, a grande modificação introduzida foi a alteração, ou melhor, a exclusão de parecer dos auditores independentes sobre a avaliação da administração sobre os controles internos da empresa. 
Entre os pronunciamentos emitidos pelo PCAOB o AS2 e, mais recentemente, o AS5, é o mais complexo de atendimento, pois define critérios para que os auditores independentes avaliem os controles internos das companhias. Para que uma empresa tenha seu sistema de controles internos avaliado adequadamente pelo auditor externo é necessário o desenvolvimento das seguintes atividades:

- Analisar o desenho dos controles;

- Testar os controles para comprovar que são realmente efetivos;

- $\quad$ Detectar fraquezas no desenho e operação dos controles;

- Documentar adequadamente todos os itens acima.

Por outro lado, cabe ao auditor as mesmas etapas acima para atestar que os controles internos da companhia são confiáveis. Como a identificação ou o estabelecimento de controles é uma atividade executada após a identificação dos riscos, estes devem ser prospectados a partir das assertions que são as garantias de qualidade quanto aos valores e às informações das demonstrações financeiras. As assertions devem abranger:

- Existence or occurrence: os ativos e passivos realmente existem nas datas indicadas;

- Completeness: Não há ativos e/ou passivos não registrados e nem há omissão de disclosure;

- Valluation or allocation: ativos, passivos, receitas e despesas estão demonstrados pelo valor apropriado, segundo os princípios contábeis aceitos;

- Rights and obligations: os ativos são os direitos e os passivos são as obrigações na data indicada;

- Presentation and disclosure: informações específicas quanto a prazo, à maturidade, à recorrência e à natureza estão corretamente apontadas e reveladas.

Quando identificada uma deficiência de controle é preciso analisar qual o nível de severidade da referida ocorrência, classificando-a em: deficiência significativa ou fraqueza material. A deficiência significativa é uma deficiência de controles, ou uma combinação de várias deficiências, que afete adversamente a capacidade da empresa iniciar, autorizar, registrar, processar ou divulgar externamente dados financeiros confiáveis, em conformidade com os 
princípios de contabilidade geralmente aceitos, e que redunde em uma probabilidade mais do que remota de provocar distorções nas demonstrações financeiras. Já a fraqueza material é uma deficiência significativa, ou uma combinação de deficiências significativas, que resultem em uma probabilidade mais que remota de que um erro material seja registrado nas demonstrações financeiras.

A fraqueza material pode ser apurada a partir do resultado dos testes dos controles, das deficiências no desenho do controle ou a partir da avaliação da administração sobre os controles gerais da organização. Ainda existem outras formas do auditor independente concluir pela indicação de fraqueza material, tais como:

- $\quad$ Republicação de demonstrações financeiras para correção de erros;

- $\quad$ Identificação de erro material nas demonstrações não detectado pelo controle interno da empresa;

- Ineficiência do Comitê de Auditoria na supervisão das demonstrações financeiras e dos controles internos para o reporte financeiro;

- Ineficiência da função da auditoria interna, gerenciamento de risco e conformidade com leis;

- $\quad$ A ocorrência de fraude de qualquer magnitude por parte da administração.

Com o intuito de verificar o relacionamento de deficiências materiais e os controles internos adotados pelas empresas Weili e McVay (2005) realizaram uma pesquisa junto às empresas que divulgaram pelo menos uma deficiência material já nos padrões protagonizados pela SOX e verificaram que as deficiências provêm de insuficiências de recursos para o aprimoramento dos controles internos e que estão relacionadas com a complexidade do negócio.

Ainda na busca por evidências de melhorias com a implantação da Lei Sarbanes-Oxley, Liu (2004) verificou que as novas regras advindas da SEC proporcionaram uma redução significativa na prática de gerenciamento, melhorando a qualidade dos relatórios financeiros, principalmente no que diz respeito às elevações inadequadas de receitas comparativamente à sua redução. 
Zhang et al (2006) investigaram o relacionamento entre o comitê de auditoria, o auditor independente e a divulgação de fraquezas materiais nos controles internos nos moldes exigidos pela SOX, concluindo que as empresas com maior probabilidade de apresentarem fraquezas materiais são as que demonstraram menor número de especialistas financeiros no comitê de auditoria. Em adição, também perceberam que empresas que efetuaram troca recente da auditoria independente foram mais suscetíveis à divulgação de fraquezas de controles.

Importante ressaltar que o PCAOB sugere a utilização das orientações emanadas pelo COSO, The Committee of Sponsoring Organizations, para gerenciamento dos riscos e controles, associadas com as determinações dos auditing standards, sendo, assim, largamente utilizado pelo mercado ${ }^{6}$.

\subsection{Controle de Riscos}

O controle de riscos é um dos fatores essenciais dentro de um sistema de controles internos. Trata-se de um processo por meio do qual é possível identificar e analisar os riscos inerentes às atividades de negócio e de suporte operacional, sendo seus principais objetivos o aumento da eficiência operacional, o aperfeiçoamento do processo decisório, a preservação da imagem e a promoção da continuidade da organização.

Lima e Lopes (1999, p. 97) sintetizam a importância da conscientização organizacional para controle dos riscos:

O compromisso organizacional é ponto fundamental para que seja criado um ambiente de controle adequado. Se a alta administração da empresa, seus gerentes e a própria cultura organizacional não possuem um compromisso com o controle financeiro da entidade e da manutenção da saúde financeira da mesma não irão surtir efeitos as tentativas de se desenvolver complexos sistemas de controle de riscos, por melhores que sejam. Se não houver um comprometimento de toda a organização, os procedimentos de controle de riscos somente ficarão no papel sem possuir qualquer impacto organizacional.

\footnotetext{
${ }^{6}$ Maiores detalhes sobre o COSO encontram-se no Apêndice 1.
} 
Risco pode ser definido como um evento, esperado ou não, que pode causar impacto no capital ou ganhos de uma organização. Paxson e Wood (1998, p. 159) fornecem a seguinte definição:

\footnotetext{
Risco pode simplesmente ser definido como exposição à mudança. É a probabilidade de que algum evento futuro ou conjunto de eventos ocorra. Portanto a análise do risco envolve a identificação de mudanças potenciais adversas e do impacto esperado como resultado na organização.
}

Na literatura, várias são as tipologias para os riscos, sendo que essa segregação por classes leva em consideração as diferenças existentes tanto na causa das perdas como nos seus efeitos para a instituição. Além disso, é comum utilizar-se de subclassificações dentro de cada classe, o que auxilia no gerenciamento do risco (TRAPP, 2004, p. 26). Dessa forma, a estrutura e classificações a serem utilizadas devem ser aquelas que melhor reflitam o comportamento da empresa.

Contudo, consoante Duarte (1999, p. 2), é possível sintetizar a tipologia dos riscos em quatro grandes grupos: risco de mercado, risco de crédito, risco legal e risco operacional.

\subsubsection{Risco de mercado}

$\mathrm{O}$ risco de mercado corresponde à probabilidade de variação no valor de ativos e passivos causada pelas incertezas de mudanças nos preços e taxas de mercado. Assim, sempre que uma instituição financeira assume uma posição a descoberto, comprada ou vendida, em títulos de renda fixa, ações, mercadorias e derivativos, e os preços variam em direção oposta à esperada, existe risco de mercado.

Saunders (2000, p. 178) elucida cinco principais motivos para o controle do risco de mercado:

- Informação gerencial - fornecer informação sobre a exposição ao risco dos operadores à alta administração;

- Estabelecimento de limites - com base nas medidas de risco de mercado das carteiras dos operadores, permite estabelecer limites de posição por operador e por tipo de operação; 
- $\quad$ Alocação de recursos - com base nessas medidas, pode-se comparar o risco/retorno das operações e então identificar as áreas com maior retorno potencial na qual poderá ser investido um maior volume de recursos;

- Avaliação de desempenho - da mesma forma, pode-se estabelecer uma política de remuneração variável mais racional com base na análise de risco/retorno das operações, à medida que nem sempre os maiores retornos são os das operações com menores riscos e vice-versa;

- Regulamentação - a mensuração do risco de mercado é importante à medida que as normas de exposição ao risco vão tornar-se mais abrangentes e restritivas.

\subsubsection{Risco de crédito}

Como risco de crédito, tem-se o risco de um devedor deixar de cumprir os termos de qualquer contrato, ou seja, caracteriza-se pelo não recebimento de obrigações a pagar pelo devedor.

Como não há um valor de mercado para o crédito e não há séries históricas disponíveis para se calcular o desvio padrão, suas variáveis são mais difíceis de mensurar, tornando sua mensuração menos precisa que do risco de mercado. As posições atuais também podem não representar os riscos futuros, uma vez que a exposição ao risco de crédito geralmente é de longo prazo.

\subsubsection{Risco legal}

O risco legal é representado pela possibilidade de sanções por órgãos fiscalizadores originados pela inobservância de leis e regulamentos, tornando-se potencial fonte de perdas.

Duarte (1999, p. 3) define risco legal como sendo uma "[...] medida numérica da incerteza dos retornos de uma instituição caso seus contratos não possam ser legalmente amparados por falta de representatividade e/ou autoridade por parte de um negociador por documentação insuficiente, insolvência ou ilegalidade.”

Já para Santomero (1997, p. 10), o risco legal está relacionado à possibilidade de mudanças jurídicas que não estariam previstas em contratos e, como exemplo, faz menção a uma 
ocorrência de mudanças nas leis ambientais que, por conseqüência, afetou o preço dos imóveis, e, respectivamente, algumas garantias hipotecárias.

\subsubsection{Risco operacional}

A definição dos eventos que se enquadram sob o âmbito do risco operacional não é uniforme, em virtude, sobretudo, da amplitude da sua conceituação. A respeito disso, Crouhy et al (2001, p. 475) declaram que:

\footnotetext{
Risco operacional permanece um conceito vago porque é difícil fazer uma distinção clara entre risco operacional e as normais incertezas enfrentadas pela organização em suas operações diárias. Por exemplo, se um cliente falhou em devolver um empréstimo, então se pode razoavelmente investigar se o fracasso era devido a qualquer risco de crédito normal, ou devido a erro humano por parte dos responsáveis pelo empréstimo
}

Entre as várias definiç̧ões para o risco operacional, a mais utilizada é o conceito definido pelo Comitê de Basiléia (The new Basel capital accord, 2001, p. 94) sendo "o risco de perda direta ou indireta, resultante de inadequações ou falhas de processos internos, pessoas e sistemas, ou de eventos externos."

Independentemente da tipologia de riscos utilizada pelas organizações a identificação dos riscos deve ser feita de forma integrada, uma vez que alterações em um único risco podem afetar outros que, de alguma forma, estariam envolvidos. Lima e Lopes (1999, p. 103) exemplificam que um caso típico desse problema é a relação que existe entre o risco de crédito e o de mercado, pois em aumentando a volatilidade de determinado título, a situação de crédito da organização possuidora desse título irá se alterar.

Todavia, ressalta-se que a preocupação com a gestão de riscos e a conseqüente criação de ambientes que possibilitassem o seu controle surgiu, principalmente, com a instabilidade do mercado financeiro, representada pela volatilidade das taxas de juros e câmbio, pela expansão das atividades financeiras a outros países e pela criação de importantes instrumentos financeiros. A seguir, é apresentado um breve histórico dos normativos que culminaram na gestão de riscos. 


\subsubsection{Breve Histórico do Controle de Riscos}

Tendo como objetivo controlar as situações adversas decorrentes das atividades financeiras e possibilitar a supervisão dos bancos, os dirigentes dos bancos centrais do G-10 (Alemanha, Bélgica, Canadá, Estados Unidos, França, Itália, Japão, Países Baixos, Reino Unido, Suécia e Suíça) criaram o Comitê de Supervisão Bancária da Basiléia, Basel Committee on Banking Supervision, no ano de 1974. Sua primeira reunião ocorreu em fevereiro de 1975 e resultou no Basle Concordat o qual estabeleceu os trabalhos que seriam desenvolvidos pelo então formado comitê.

A sede do Comitê da Basiléia está localizada no BIS, Bank for International Settlements, que é uma organização internacional que visa promover a cooperação entre os bancos centrais e as instituições financeiras internacionais. Dessa forma, mesmo não tendo autoridade de supervisão supranacional formal, o Comitê da Basiléia trabalha juntamente às autoridades supervisoras locais de diversos países objetivando defender e difundir suas propostas de redução de riscos do sistema financeiro e a estabilidade da atividade bancária internacional. Segundo Securato e Perobelli (2002, p.2), tal aceitabilidade decorre do fato de:

[...] estimular a convergência das técnicas de supervisão dos países membros a padrões e abordagens comuns, o que viabiliza o fluxo de capitais entre os países sem impor barreiras mas garantindo a segurança desses capitais.

Em julho de 1988, foi publicado o primeiro acordo da Basiléia intitulado International Convergence of Capital Measurement and Capital Standards que buscava a padronização internacional da supervisão bancária, definindo os componentes do capital, uma estrutura para ponderação dos riscos dos ativos e o capital mínimo para suportar os riscos de crédito existentes nas operações bancárias. Em 1996, o Comitê da Basiléia incorporou o risco de mercado nos requisitos para a definição do capital mínimo a partir do adendo intitulado Amendment to the Capital Accord to Incorporate Market Risks, estabelecendo um método para o cálculo do risco de mercado, mas também possibilitando que as instituições financeiras utilizem metodologias próprias para mensuração e gerenciamento dos riscos.

A necessidade de controle do grau de exposição ao risco operacional surge na década de 90 no documento The New Basel Capital Accord, ou "Novo Acordo da Basiléia", que propõe um capital suporte para fazer face também a esse tipo de possibilidade de perda. 
A partir dos conceitos e recomendações advindos do Comitê da Basiléia, em agosto de 1994, o Conselho Monetário Nacional, por meio do Banco Central do Brasil, divulgou a Resolução CMN n. ${ }^{\circ} 2.099$ iniciando-se, assim, o desenvolvimento e a implantação das recomendações da Basiléia no mercado interno. Dentre as medidas publicadas, destacam-se:

- Exigência de valores mínimos de capital, na qual o capital mínimo dos bancos tem relação direta com a estrutura dos seus ativos e dos seus respectivos riscos;

- O ativo passou a ser dividido em classes, sendo que a exigência de capital estaria vinculada diretamente à classe de risco a qual o ativo estivesse enquadrado;

- O risco deixou de ser medido no passivo, para ser medido no ativo, uma vez que o capital deveria representar, no mínimo, $8 \%$ dos ativos ponderados pelo risco.

Ainda em 1994, o Conselho Monetário Nacional alterou a fórmula de cálculo do valor de patrimônio líquido ajustado descrito na Resolução CMN n. ${ }^{\circ}$ 2.099, adicionando as operações de swap (Resoluções CMN n.os 2.138 e 2.139) e em julho de 1997 novamente o cálculo foi alterado (Resolução CMN n. ${ }^{\circ}$ 2.399).

Ainda sobre o capital mínimo exigido, o Conselho Monetário Nacional, por meio do Banco Central do Brasil, estabeleceu novo conceito de capital mínimo compatível com o grau de risco das operações ativas das instituições financeiras com a Resolução CMN n. ${ }^{0}$ 2.543, de agosto de 1998, atualizada posteriormente pelas Resoluções CMN n. ${ }^{\circ}$ 2.802/2000, CMN n. ${ }^{\circ}$ 2837/2001 e, mais recentemente, pela CMN n. ${ }^{\circ} 3444 / 2007$.

Em maio de 1997, foi a publicada a Resolução CMN n. ${ }^{\circ}$ 2.390, que criou a Central de Risco de Crédito, responsável pela consolidação de informações sobre operações de crédito realizadas no Sistema Financeiro Nacional constituindo, assim, um importante procedimento para identificação, mensuração e controle de risco de crédito, tanto para o Banco Central do Brasil quanto paras as instituições financeiras que podem evitar riscos resultantes de empréstimos concedidos aos clientes, uma vez que as informações contidas na base podem ser consultadas pelas instituições, desde que sejam autorizadas.

Em junho de 2006, o CMN emitiu a primeira resolução voltada apenas para o risco operacional. Referida resolução, $\mathrm{CMN}$ n. ${ }^{\circ}$ 3.380, determinou que as instituições financeiras 
implantassem uma estrutura para gerenciamento do risco operacional até dezembro de 2007. Importante ressaltar que o risco legal ficou associado ao risco operacional.

A definição utilizada para risco operacional é a mesma definida por Basiléia "[...] a possibilidade de ocorrência de perdas resultantes de falha, deficiência ou inadequação de processos internos, pessoas e sistemas, ou de eventos externos." Os eventos de risco operacional também são os mesmos definidos por Basiléia, quer sejam: fraudes internas; fraudes externas; demandas trabalhistas e segurança deficiente do local de trabalho; práticas inadequadas relativas a clientes, produtos e serviços; danos a ativos físicos próprios ou em uso pela instituição; aqueles que acarretem a interrupção das atividades da instituição; falhas em sistemas de tecnologia da informação; falhas na execução, cumprimento de prazos e gerenciamento das atividades na instituição.

Vários outros documentos foram e estão sendo emitidos pelo Conselho Monetário Nacional, sempre buscando o gerenciamento do risco nas instituições financeiras. 


\section{GERENCIAMENTO DE RESULTADOS CONTÁBEIS (EARNINGS}

\section{MANAGEMENT)}

\subsection{Definição de gerenciamento de resultados}

A contabilidade insere-se no propósito principal de fornecer informações úteis para os diversos agentes econômicos e, muitos destes, possuem interesse sobre a situação financeira das empresas. Logo, muitas decisões do mercado de capitais são diretamente afetadas pelos números por ela demonstrados.

A respeito disso, Beaver (1981, p. 50) ressalta que a informação contábil pode trazer conseqüências relevantes para os seus usuários, tais como afetar a distribuição de riquezas entre acionistas, alterar a percepção de risco ou a forma pela qual os investimentos são alocados dentro da empresa.

Autoridades reguladoras e o próprio mercado de capitais têm usado vários mecanismos para reduzir a prática de gerenciamento de resultados, seja por meio de desenvolvimento de padrões contábeis, execução de trabalhos de auditoria cada vez mais rígidos, verificação de cumprimento de normas, aumento do disclosure das informações ao mercado.

De forma geral, na literatura acadêmica, o termo gerenciamento de resultados têm sido utilizado como um ato intencional utilizado pelo administrador para alterar os valores apresentados nas demonstrações financeiras como forma de se obter algum benefício particular.

O ato intencional acima citado é mencionado na definição de Schipper (1989, p. 92) que define gerenciamento de resultado como “[...] uma intervenção proposital no processo de elaboração das demonstrações financeiras externas, com a intenção de obter algum ganho pessoal [...]". 
Healy (1998, p. 6), em seu trabalho de revisão da literatura existente sobre earnings management (gerenciamento de resultados) elaborou definição relacionando-a com sua ocorrência:

Gerenciamento de resultados ocorre quando os administradores usam de julgamento nos demonstrativos financeiros e na estrutura das transações para alterar os relatórios financeiros ou para enganar alguns stakeholders sobre a performance econômica da companhia, ou para influenciar os resultados contratuais que dependem dos números contábeis reportados.

O autor enfatiza em sua definição que se trata da utilização de "julgamento" com o intuito de “enganar”. Assim, é importante ressaltar o aspecto de ludibriar existente na definição, uma vez que o julgamento por si só está intrínseco em muitos aspectos da contabilidade. A administração pode, por exemplo, decidir por critérios de depreciação de acordo com a expectativa de vida de determinado equipamento, ou determinar critérios para constituição de provisão para devedores duvidosos levando-se em consideração as particularidades do negócio sem, contudo, existir o intuito de manipular o usuário da informação contábil.

Parfet (2000, p. 486) declara que o uso de julgamento e subjetividade, inclusive, é desejável, cabendo ao contador ou auditor aplicar seus conhecimentos para determinar a melhor forma de registro das transações.

Ademais, ainda segundo o mesmo autor (PARFET, 2000, p. 485), existe também o "bom" gerenciamento de resultados que se utiliza de práticas corretas e razoáveis que fazem parte da operação de uma empresa bem administrada e que gera valor aos acionistas, uma vez que empresas de alto padrão de gerenciamento controlam os resultados de orçamento, monitoram o mercado, reagem às oportunidades tempestivamente. Dessa forma, poderia ser considerado um gerenciamento de resultados oportuno, quando, por exemplo, o administrador ao acompanhar os resultados alcançados resolve fechar a fábrica mais cedo porque já foi atingido o objetivo de produção. Produziria, assim, um resultado gerenciado que não estaria provocando alterações nos números contábeis.

O problema central, então, é como o responsável pelos dados contábeis vai utilizar seu poder de decisão para realizar a escolha mais adequada. Lopes (2004, p. 178) ao dissertar sobre a importância do lucro produzido pela contabilidade, ressalta, novamente, o aspecto da subjetividade e que, em algumas situações, os administradores não decidem de forma neutra: 
[...] o lucro, como todas as medidas em contabilidade, possui aspecto subjetivo considerável. Os accruals (ou ajustes oriundos do regime de competência), são, muitas vezes, totalmente discricionários, permitindo que os administradores tenham alguma liberdade em sua mensuração (também conhecida como manipulação dos resultados). No entanto, essa liberdade não é exercida de forma neutra. Os administradores respondem a impulsos internos e externos que podem levar a essa ou aquela forma de manipulação. Os administradores de uma empresa, por exemplo, que esteja passando por dificuldades, devido aos covenants de suas dívidas, podem ser levados a manipular os lucros no sentido de aumentá-los. Por outro lado, uma empresa que esteja sendo acusada de monopólio pode tentar reduzir seus lucros a fim de não parecer ser tão lucrativa assim. Dessa forma, pode-se ver quanto a "gestão do resultado contábil responde a inúmeras formas de pressão, externas e internas". [...]

Faz-se importante ressaltar, também, que quando do gerenciamento de resultado, o administrador tem o intuito de manipular os dados dentro dos limites existentes na legislação contábil, ou seja, utilizando-se da flexibilidade existente nos próprios princípios contábeis, caso contrário seria fraude contábil e não gerenciamento de resultados. Por conseguinte, a escolha dos critérios contábeis pode propiciar ao gestor a possibilidade de fornecer aos usuários relatórios contábeis com melhores ou piores resultados. Muldorf e Cominskey (2002, p. 65) elencam algumas possibilidades de flexibilização de resultados apenas utilizando os princípios contábeis geralmente aceitos, tratam-se, quase que basicamente, de postergações no reconhecimento de despesas e antecipações no reconhecimento de receitas:

- Mudança de vida útil de máquinas e equipamentos com o intuito de alterar a depreciação;

- Mudança de estimativa de valor residual;

- $\quad$ Determinação da provisão de devedores duvidosos;

- $\quad$ Determinação da provisão para garantia de produtos;

- Definição da provisão para impostos diferidos no ativo;

- $\quad$ Estimação do estágio de finalização de contratos de longa duração;

- Determinação de premissas atuariais;

- $\quad$ Determinação de provisão para despesas de reestruturação;

- $\quad$ Estimação de valores para baixa contábil de estoques;

- $\quad$ Estimação da probabilidade de reclamações contratuais;

- Decisão sobre a política de riscos com derivativos;

- $\quad$ Decisão sobre valor de mercado de um investimento. 
Buscando fornecer uma distinção entre escolhas fraudulentas e escolhas "agressivas", mas aceitáveis (gerenciamento de resultado), Dechow e Skinner (2000, p. 25) elaboraram uma lista com exemplos, a qual foi adaptada por Martinez (2001, p. 14) e é demonstrada a seguir:

Quadro 2 - Distinção entre fraude e gerenciamento de resultados

\begin{tabular}{|c|c|c|c|}
\hline & Decisões contábeis "puras" & & ecisões com impacto no fluxo de caixa \\
\hline \multicolumn{4}{|c|}{ "Gerenciamento" dos resultados contábeis } \\
\hline \multicolumn{2}{|r|}{ De acordo com as Normas / Princípios Contábeis } & & Práticas Aceitáveis \\
\hline & Contabilidade "Conservadora" & \multicolumn{2}{|r|}{ Visando Reduzir Fluxo de Caixa Líquido } \\
\hline a) & Reconhecimento muito elevado de provisões; & & Retardar vendas \\
\hline & Aceleração das despesas de depreciação; & & $\begin{array}{l}\text { Acelerar gastos associados à propaganda e } \\
\text { publicidade, treinamento e P\&D. }\end{array}$ \\
\hline \multirow[t]{2}{*}{ c) } & $\begin{array}{l}\text { Reconhecimento de receitas apenas quando da } \\
\text { cobrança. }\end{array}$ & & $\begin{array}{l}\text { Aumentar Despesas de natureza não- } \\
\text { operacional (Banquetes, Bingos, Doações) }\end{array}$ \\
\hline & Contabilidade "Agressiva" & \multicolumn{2}{|c|}{ Visando Aumentar Fluxo de Caixa Liquido } \\
\hline a) & $\begin{array}{l}\text { Evitar ou reduzir o reconhecimento de } \\
\text { provisões; }\end{array}$ & & Antecipar ou acelerar as vendas; \\
\hline b) & Reduzir as cotas de depreciação e amortização. & & $\begin{array}{l}\text { Adiar a realização de despesas necessárias de } \\
\text { propaganda \& publicidade, treinamento ou } \\
\text { P\&D; }\end{array}$ \\
\hline c) & $\begin{array}{l}\text { Reconhecimento de receitas durante a } \\
\text { produção. }\end{array}$ & c) & $\begin{array}{l}\text { Aumentar Receitas não operacionais pela } \\
\text { venda de Ativos da empresa. }\end{array}$ \\
\hline \multicolumn{4}{|c|}{ Contabilidade Fraudulenta e Práticas Inaceitáveis } \\
\hline \multicolumn{2}{|r|}{ Que violam as Normas / Princípios Contábeis } & \multicolumn{2}{|r|}{ Práticas Inaceitáveis } \\
\hline & Registrar vendas fictícias; & a) & Receber e não efetuar a entrega do produto; \\
\hline b) & $\begin{array}{l}\text { Antecipar (documentalmente) a data de } \\
\text { realização das vendas; }\end{array}$ & & $\begin{array}{l}\text { Não cumprir com os compromissos } \\
\text { financeiros; }\end{array}$ \\
\hline & $\begin{array}{l}\text { Superestimar o estoque pelo registro de } \\
\text { inventário fictício. }\end{array}$ & & Não pagar tributos lançados. \\
\hline
\end{tabular}

Fonte: Dechow e Skinner (2000, p. 25) apud Martinez (2001, p. 14)

Por fim, as regras contábeis não podem ser a única proteção para eventuais abusos dos gestores, outros aspectos devem ser considerados na elaboração dos demonstrativos financeiros, tais como a ética das empresas e de seus altos executivos, o gerenciamento de riscos e a estrutura de controles internos, a efetividade do comitê de auditoria, a capacidade 
dos auditores externos, a fiscalização e respectiva punição que se fizer necessária pelos órgãos reguladores.

\subsection{Razões para gerenciamento de resultados}

Existem muitas razões para a prática de gerenciamento de resultados. Mohanram (2003, p. 02) explicita que dentre todos os motivos existe uma razão fundamental que está intimamente ligada à performance da empresa e seu relacionamento com algum ponto ou medida de referência (benchmark), sendo que referido ponto de referência pode ser a o resultado de períodos anteriores, expectativas dos analistas de mercado ou, até mesmo, os contratos de remuneração dos administradores.

Moharam (2003, 02) afirma, ainda, que perder algumas dessas expectativas pode ser extremamente custoso porque a relação entre o preço da ação (ou remuneração dos administradores) e os resultados é não linear em torno dos benchmarks. Isto quer dizer que se uma determinada empresa deixa de atingir a meta ou expectativa de mercado por pouco poderá verificar uma queda súbita no preço de suas ações, enquanto, em contrapartida, uma empresa que tenha superado a meta, também por pouco, verificará um bom incremento no valor das suas ações.

Ao dissertarem sobre a teoria positiva ${ }^{7}$, Watts e Zimmerman (1986, p. 138-139) desenvolveram três hipóteses que orientaram os estudos para explicar e predizer certas práticas contábeis adotadas pelas empresas, a saber: plano de incentivo (bonus plan), grau de endividamento (debt/equity) e custos políticos (political cost). É de se notar que citadas hipóteses também servem de base para o entendimento dos motivos que levam ao gerenciamento de resultados.

\footnotetext{
${ }^{7}$ A teoria positiva difundiu-se com maior profundidade na década de 1980, principalmente devido aos trabalhos de Watts e Zimmerman (1986). Referida teoria está baseada em observações da realidade e na realização de testes de hipóteses empíricos sobre determinados fenômenos.
} 


\subsubsection{Motivação por plano de incentivo (bonus plan)}

A hipótese de plano de incentivo é de que os administradores das empresas que recebem algum tipo de bônus ou remuneração variável tentarão utilizar-se de métodos contábeis para aumentarem os resultados do período (WATTS e ZIMMERMAN, 1986, p. 138).

Healy (1985) realizou uma pesquisa na qual constatou vários casos em que os executivos gerenciavam os resultados baseados nos citados programas de recompensas. Assim, quando estes notavam uma expectativa de se atingir os resultados necessários para uma "recompensa" utilizavam-se de técnicas que pudessem maximizar a sua realização. Por outro lado, quando percebiam que as expectativas não seriam atingidas, utilizavam-se de técnicas que pudessem reduzir ainda mais o resultado, vislumbrado uma super avaliação do lucro nos períodos posteriores.

Outros estudos foram realizados para examinar o relacionamento dos contratos de incentivos dos executivos com o gerenciamento de resultados. Estes estudos testaram se há um aumento na freqüência de earnings management nos períodos em que altos executivos tem a sua posição ameaçada ou quando existe uma expectativa de permanecer na empresa por um curto período de tempo (HEALY e WAHLEN, 1998, p. 21). Na mesma linha de pesquisa, Dechow and Sloan (1991) verificaram que em seus últimos anos na empresa os CEOs (Chief Executive Officer) reduziam os gastos com pesquisa e desenvolvimento presumivelmente para aumentar os resultados reportados.

\subsubsection{Motivação por grau de endividamento (debt/equity)}

A hipótese do grau de endividamento sugere que as empresas que possuem graus de endividamento maiores estão mais propensas a usar métodos contábeis que aumentem o lucro, uma vez que quanto maior o endividamento, mais a empresa estará sufocada pelas restrições contratuais impostas pelos credores (WATTS e ZIMMERMAN, 1986, p. 139). E para manter os níveis de lucros ou os índices financeiros geralmente exigidos pelos respectivos credores, os administradores utilizam-se de técnicas para melhorar os resultados. 


\subsubsection{Motivação por custos políticos (political cost)}

A hipótese dos custos políticos estabelece que grandes empresas usem técnicas para reduzir os lucros mais freqüentemente que as pequenas, o que está relacionado com a premissa que o tamanho da empresa é um estimador da atenção política que a empresa recebe (WATTS e ZIMMERMAN, 1986, p. 139).

Ainda nesta hipótese é possível subdividir a motivação relacionada aos custos políticos de gerenciamento de resultados em três segmentos: a) para enganar os órgãos reguladores; b) para reduzir o risco de intervenções e investigações; c) para planejamento tributário.

\subsubsection{Motivação pelo Mercado de Capitais}

A utilização das informações contábeis pelos investidores e analistas de mercado propicia mais uma hipótese ou categoria de motivação para o gerenciamento de resultados, com o intuito de influenciar no valor da ação, por exemplo.

Teoh et al (1998) verificou que algumas empresas superestimam seus lucros no período de lançamento de IPO (initial public offers). Payne e Robb (2000) reporta que algumas empresas gerenciam seus resultados para compatibilizá-los com as expectativas de analistas e investidores. Sloan (1996) identifica que os retornos futuros das ações são negativos para as empresas cujos lucros correntes incluem grandes accruals, e positivo para empresas com pequenos accruals. Em resumo, o que pode ser verificado pela literatura é que pelo menos algumas empresas manipulam os resultados por razões relacionadas ao mercado de capitais.

\subsection{Tipos de gerenciamento de resultados}

De acordo com a motivação para o gerenciamento de resultados é possível classificar alguns tipos de manipulação utilizados. Mohanram (2003, p. 02) os relaciona em três classificações: Bump up, Big Bath e Cookie Jar.

Todas as três classificações estão relacionadas com um objetivo de resultado (target), a diferença entre elas centra-se no posicionamento contábil da empresa perante respectivo 
resultado e, por conseqüência, nas atitudes que serão tomadas pelos seus administradores. Por exemplo, quando as empresas estão extremamente próximas de atingir seus objetivos de resultado, os incentivos para gerenciá-lo e utilizarem-se de técnicas que possam aumentar os lucros são muito fortes, sendo esta a característica bump up.

Por outro lado, quando as empresas estão abaixo de suas metas de resultado, a tendência é fazerem uso de técnicas contábeis que possam piorar ainda mais os resultados em prol de melhoria em resultados futuros (tais como mudanças de reestruturação, aumento de provisões para créditos ruins entre outros), é o que a literatura conhece por big bath. Em compensação, se as empresas estão acima da meta, isso também pode ser um incentivo para a redução no resultado com o intuito de ajustá-lo para ficar apenas um pouco acima do previsto (meta), caso contrário, as expectativas de mercado para os próximos períodos poderiam aumentar muito, tornando-se difícil para a empresa alcançar os novos patamares exigidos, é o que se chama de cookie jar. A figura a seguir ilustra o comportamento dos administradores em torno da meta e os tipos de gerenciamento de resultados.

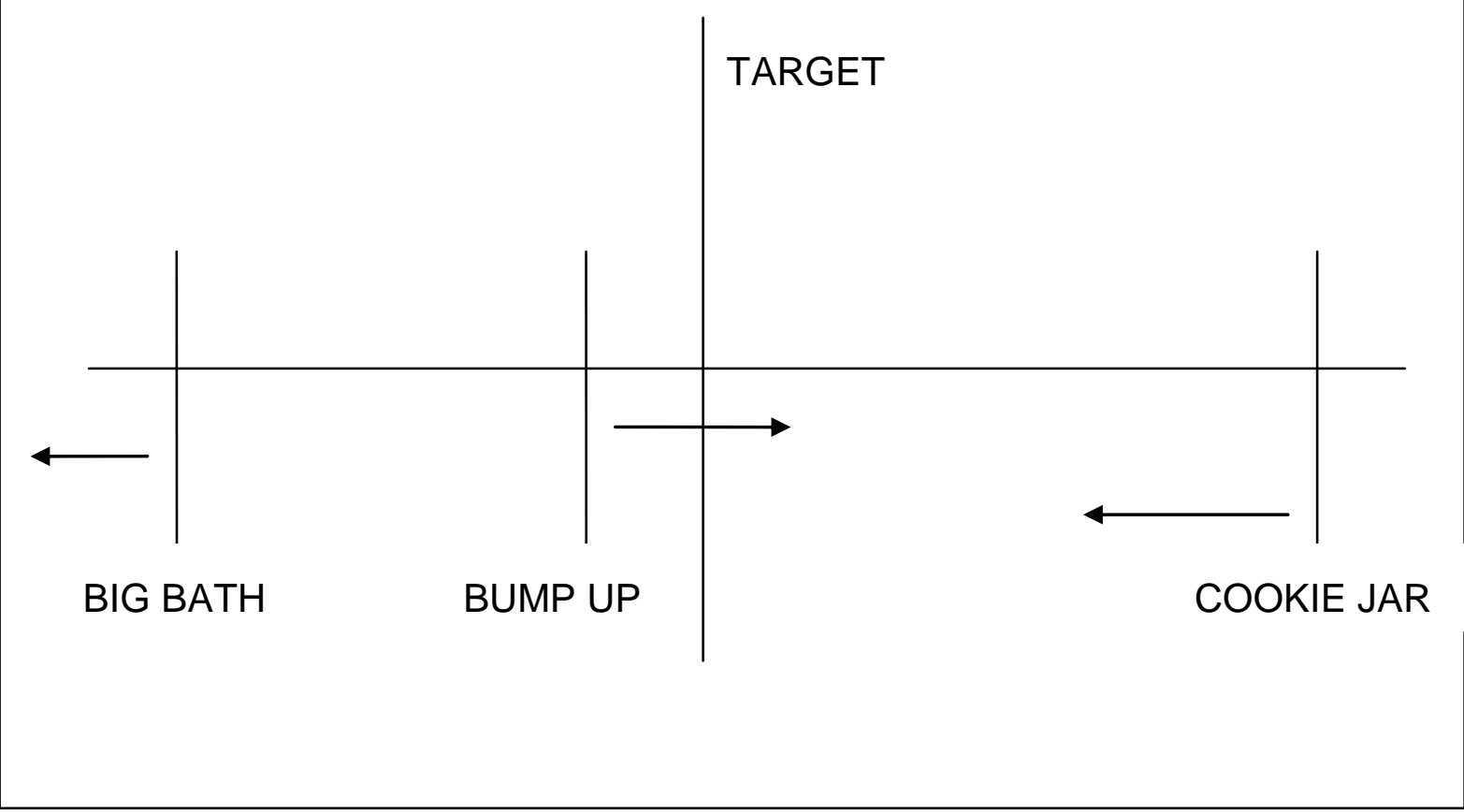

Ilustração 4 - Tipos de gerenciamento de resultado Fonte: Mohanram (2003, p. 04) 
Alguns autores também citam income smoothing como um tipo de gerenciamento de resultado voltado para gerenciá-lo de forma a reduzir sua variabilidade. Myers et al (2006, p. 06) relatam que a suavização de resultados pode fazer transparecer aos investidores uma menor volatilidade e risco nas taxas de retorno das empresas.

\subsection{Metodologias para evidenciação de gerenciamento de resultados}

Mohanram (2003, p. 06) trabalha com duas abordagens para detecção de gerenciamento de resultados, sendo a primeira um método baseado em uma análise qualitativa detalhada das práticas contábeis utilizada pela empresa(s) em estudo, e a segunda, um método baseado na análise quantitativa dos accruals.

$\mathrm{Na}$ análise qualitativa detalhada, é sugerido o desenvolvimento dos seguintes passos:

I. Identificar quais as políticas contábeis mais importantes para o ramo de empresa que está sendo estudado, por exemplo, para companhias aéreas o item depreciação seria um dos mais importantes;

II. Avaliar a flexibilidade contábil adotada pela empresa:

a) Qual sua reação na escolha de uma prática contábil?

b) Geralmente a empresa é mais conservadora ou agressiva?

III. Avaliar a estratégia contábil da empresa:

a) Como a estratégia contábil difere das estratégias dos concorrentes?

c) As políticas e estimativas contábeis adotadas no passado foram realistas?

d) A empresa mudou alguma política significativa? E qual foi o impacto?

e) Os administradores têm incentivos para o uso de "contabilidade oportunística" (por exemplo, bônus ou planos de compensação)?

IV. Avaliar a qualidade do disclosure da empresa: 
a) A empresa fornece informações adequadas para que se possa entender as estratégias econômicas das operações?

b) As escolhas contábeis são justificadas adequadamente?

c) Há detalhamento de análises de performance passada?

d) Há detalhes sobre o segmento do setor?

e) O programa de relação com o investidor é adequado?

f) A companhia dá o mesmo tratamento para divulgação de boas e más notícias?

V. Análise e identificação de pontos de alerta (red flags), sendo que a presença de muitos pontos de alerta certamente irá requerer um exame minucioso. Alguns pontos de alerta:
a) Mudanças contábeis não explicadas, especial se a performance foi ruim;
b) Transações para aumento de lucros não explicadas, por exemplo, venda de ativo;
c) Aumento não usual nas contas de recebíveis em relação ao aumento nas vendas;
d) Aumento da diferença entre o Lucro Líquido e o Fluxo de Caixa Operacional;
e) Grande baixa de ativos inesperada;
f) Vários ajustes no quarto trimestre;
g) Qualificação da opinião dos auditores, ou troca da empresa de auditoria;
h) Muitas transações entre partes relacionadas.

VI. Desfazer as distorções contábeis revertendo os impactos contábeis duvidosos sempre que possível, uma vez que para uma análise financeira adequada faz-se necessário trabalhar com relatórios "limpos" ou sem viés.

A análise quantitativa dos accruals é muito utilizada nas pesquisas empíricas sobre earnings management. Corroborando e acrescentando à definição de Mohanram (2003), Martinez (2000) declara que na literatura disponível sobre gerenciamento de resultados são encontradas três metodologias para estudos empíricos: estudos com base na distribuição de freqüências; estudos com base na análise de accruals específicos; estudos com base no agregado de accruals, buscando estimar accruals discricionários.

Os estudos empíricos baseados na distribuição de freqüências verificam o comportamento contábil relacionando-o com um ponto de referência (benchmarks), que pode ser o resultado do ano anterior e lucro zero, e, por conseguinte, relaciona se as observações dos resultados 
contábeis abaixo desse ponto são muito diferentes do número de observações acima do valor estabelecido. Tem como principal vantagem não trabalhar com a estimação de accruals, contudo, não permite verificar de que forma foi realizado o gerenciamento de resultado.

A análise de accruals específicos tem por objetivo analisar o comportamento de determinados ramos de empresas ou contas contábeis específicas com o intuito de personalizar a modelagem ao problema (indústria ou conta) que está sendo estudado. Contudo, nesta metodologia são necessários grandes números de observações, que nem sempre estão disponíveis.

Healy (1985) foi o primeiro a utilizar o modelo com base em accruals agregados, cuja abordagem procura estimar o componente discrionário dos accruals. Jones (1991) utilizou-se de regressões para estimar os accruals não discricionários e, por conseguinte, estimar indiretamente o valor dos accruals discrionários. A abordagem de Jones será objeto deste trabalho, assim, referida metodologia será mais bem detalhada adiante. Contudo, neste ponto faz-se necessário entender primeiro accruals, bem como suas finalidades para a contabilidade.

\subsubsection{Accruals e o regime de competência contábil}

Conforme citado anteriormente, a utilidade da contabilidade está relacionada com o seu poder de informação e, conseqüentemente, seu conteúdo informativo centra-se principalmente no regime de competência, que por sua vez, tem sua utilidade relacionada aos accruals. A respeito disso, Lopes e Martins (2005, p. 72) afirmam que:

[...] podemos ver que a utilidade do sistema de informações contábeis está em fornecer sinais que possuam valor para alterar as crenças dos investidores. A contabilidade fornece sinais [...]. Esses sinais têm como função reduzir a assimetria entre gestores e o mercado, adicionando valor para os usuários dessa forma. No entanto, conforme visto, os accruals é que cumprem esse papel. $\boldsymbol{E}$ nos accruals que reside o conteúdo informativo da contabilidade, medida que eles fornecem informações ao mercado. Quando os gestores decidem utilizar dada taxa de depreciação, por exemplo, eles acabam por informar o mercado sobre a situação dos ativos da empresa. A assimetria informacional é quebrada dessa forma.

O regime de competência, estrutura básica da contabilidade, estabelece o reconhecimento das despesas e receitas no período de sua ocorrência, desvinculando-o de qualquer forma de recebimento, o qual pode até ter acontecido. A Resolução CFC, Conselho Federal de Contabilidade, $n^{\circ}$ 750, de dezembro de 1993 traz, em sua seção VI, artigo 9 , a definição para 
regime de competência em relação às receitas e despesas citando que "as receitas e as despesas devem ser incluídas na apuração do resultado do período em que ocorrerem, sempre simultaneamente quando se correlacionarem, independentemente de pagamento [...]". Ou ainda, segundo Iudícibus (1997, p. 103):

\begin{abstract}
A Competência é o Princípio que estabelece quando um determinado componente deixa de integrar o patrimônio, para transformar-se em elemento modificador do Patrimônio Líquido. Da confrontação entre o valor final dos aumentos do Patrimônio Líquido - usualmente denominadas "receitas" - e das suas diminuições - normalmente chamadas de "despesas" -, emerge o conceito de "resultado do período": positivo, se as receitas forem maiores do que as despesas; ou negativo, quando ocorrer o contrário.
\end{abstract}

Vários pronunciamentos do FASB, Financial Accounting Standards Board, em seus Statement of Financial Accounting Concepts também podem ajudar a elucidar o regime de competência (DECHOW e SKINNER, 2000, p. 03):

O foco primário da divulgação financeira é informação sobre uma performance empresarial fornecida pelas medidas de lucro e seus componentes [CON1, para. 43]...O regime de competência tenta registrar os efeitos financeiros sobre uma entidade em períodos nos quais aquelas transações, eventos, e circunstâncias ocorrem melhor do que somente em períodos nos quais o caixa é recebido ou pago por uma entidade [CON6, para. 139]... O regime de competência usa dos ajustes advindos dos accruals, diferimentos e procedimentos de alocação cujos objetivos é relatar lucros, despesas, ganhos e perdas para períodos a refletir uma performance durante um período ao invés de meramente listar as entradas e as saídas de caixa. Ainda, o reconhecimento de receitas, despesas, ganhos e perdas e incrementos e decrementos relacionados aos ativos e passivos - incluem decisão de custos e receitas, alocação e amortização - é a essência de usar o regime de competência para mensurar a performance das entidades [CON6, para. 145].

Logo, o regime de competência permite que os gestores possam ter a capacidade de previsão de fluxos futuros de caixa, por exemplo, a partir de uma venda a prazo realizada na data de hoje é possível saber, com a ajuda da provisão para devedores duvidosos, quanto se tornará caixa no futuro. Ou seja, o regime de competência diverge do caixa do período corrente, mas é essencial para a verificação do caixa nos próximos períodos.

Como visto no exemplo acima, o que se espera dos accruals (neste caso, da provisão para devedores duvidosos) é que sua informação seja relevante para o mercado (sejam analistas, acionistas entre outros), fornecendo dados adicionais para o fluxo de caixa e sobre a real situação da empresa em termos de ativos e passivos. 
Os accruals podem ser divididos em discricionários e não-discricionários, sendo que os primeiros dependem de julgamento dos administradores das empresas para a sua determinação. A escolha do método de depreciação, por exemplo, é discricionária. Por conseguinte, é nos acrruals discricionários que se pode encontrar o componente "gerenciar resultados", quando na verdade a sua utilização deveria ser a de prestar ao mercado informações adicionais e verídicas sobre a empresa. Assim, é importante ressaltar o papel crucial dos gestores no momento da realização de escolhas e, como bem cita Lopes e Martins $(2005,72)$ " [...] o poder discricionário dos gestores também deve ser utilizado de forma conservadora".

\subsubsection{Modelo de Jones}

O modelo de Jones (1991) insere-se, como visto anteriormente, na metodologia de utilização dos accruals agregados. Para tanto, calcula os accruals totais e, em seguida, os accruals nãodiscricionários. Seu modelo procura controlar os efeitos de mudanças econômicas adotadas pela empresa sobre os accruals não-discrionários, sendo que um pressuposto implícito em seu modelo é que as receitas são não-discricionárias. Assim, o accrual não-discrionário é medido pela seguinte fórmula:

$$
A N D_{i t}=\alpha_{1}\left(1 / A_{t-1}\right)+\alpha_{2}\left(\Delta \operatorname{Re} \text { ceitas }_{t}\right)+\alpha_{3}\left(P P E_{t}\right)
$$

Onde:

$\mathrm{AND}_{\mathrm{it}}=$ Accrual não-discricionário;

$\mathrm{A}_{\mathrm{t}-1}=$ Ativos totais em $(\mathrm{t}-1)$;

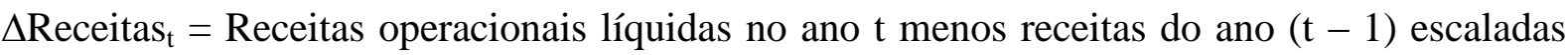
pelos ativos de $(\mathrm{t}-1)$;

$\mathrm{PPE}_{\mathrm{t}}=$ Propriedade, Planta e Equipamento em t;

$\alpha_{1}, \alpha_{2}, \alpha_{3}=$ Coeficientes estimados por regressão.

$\mathrm{i}=$ companhia.

Com o intuito de eliminar a tendência existente no modelo para mensurar accruals discricionários com erro quando a discricionaridade sobre as receitas é exercida, o modelo de Jones foi modificado. 


\subsubsection{Modelo Modificado de Jones}

Nesta versão do modelo, a única mudança com relação ao modelo original diz respeito ao ajuste nos recebíveis, assumindo-se, assim, que todas as mudanças com vendas a receber do período são resultado de gerenciamento. Logo, a nova fórmula aparece abaixo:

$$
A N D_{i t}=\alpha_{1}\left(1 / A_{t-1}\right)+\alpha_{2}\left(\Delta \operatorname{Re} \text { ceitas }_{t}-\Delta C \operatorname{Re} \text { ceber }_{t}\right)+\alpha_{3}\left(P P E_{t}\right)
$$

Onde:

$\mathrm{AND}_{\mathrm{it}}=$ Accrual não-discricionário;

$\mathrm{A}_{\mathrm{t}-1}=$ Ativos totais em $(\mathrm{t}-1)$;

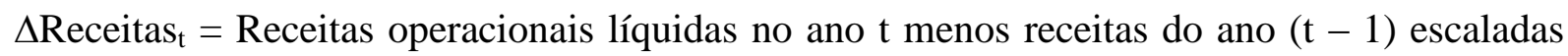
pelos ativos de $(\mathrm{t}-1)$;

$\Delta$ CReceber $_{\mathrm{t}}=$ Contas a receber líquidas no ano $\mathrm{t}$ menos contas a receber líquidas no ano $(\mathrm{t}-1)$ escaladas pelos ativos de $(\mathrm{t}-1)$;

$\mathrm{PPE}_{\mathrm{t}}=$ Propriedade, Planta e Equipamento em $\mathrm{t}$ escalados pelos ativos de $(\mathrm{t}-1)$;

$\alpha_{1}, \alpha_{2}, \alpha_{3}=$ Coeficientes estimados por regressão.

$\mathrm{i}=$ companhia.

Importante ressaltar que a premissa quanto ao gerenciamento de resultado nas vendas a receber decorre do fato de ser mais fácil gerenciar resultado pelos valores a receber do que os valores sobre o caixa (DECHOW et al, 1995, p. 199).

\subsubsection{Medidas de Leuz et al}

Em uma pesquisa empírica publicada em 2002, Leuz et al, tendo como base Heally e Wahlen (1999) e Dechow e Skinner (2000), especificaram quatro medidas para analisar o gerenciamento de resultados em trinta e um países. Também construíram uma medida, denominada aggregate measure of earnings management, calculada pela média das posições das medidas estruturadas, com o intuito de atenuar o erro de mensuração.

A primeira medida desenvolvida (EM1) visa identificar as variações na performance econômica relacionadas às decisões operacionais e escolhas de divulgação, ou seja, revela informações sobre a variabilidade dos lucros reportados. Referida medida é expressa abaixo: 


$$
E M_{1}=\sigma(L O p) / \sigma(F C O)
$$

Onde:

$\sigma(\mathrm{LOp})=$ Desvio-padrão do lucro operacional (dividido pelos ativos totais do ano anterior); $\sigma(\mathrm{FCO})=$ Desvio-padrão do fluxo de caixa operacional (dividido pelos ativos totais do ano anterior)

A segunda medida (EM2) considera a correlação entre o regime de competência e o fluxo de caixa operacional visando a suavização de lucros. Espera-se que haja entre os accruals e o fluxo de caixa operacional uma correlação negativa, contudo, se referida correlação for muito alta, isso poderia indicar a suavização de lucros reportados. A medida EM2 segue abaixo:

$$
E M_{2}=\rho(\triangle A T, \triangle F C O)
$$

\section{Onde:}

$\rho=$ Correlação;

$\Delta \mathrm{AT}=$ Variação dos Accruals Totais (dividido pelos ativos totais do ano anterior);

$\Delta \mathrm{FCO}=$ Variação do fluxo de caixa operacional (dividido pelos ativos totais do ano anterior).

A medida EM3 é estruturada para detectar o exercício da discricionaridade pelo gestor com o intuito de divulgar uma performance errônea para a empresa. Utiliza-se da magnitude dos accruals com relação ao fluxo de caixa operacional:

$$
E M_{3}=|A T| /|F C O|
$$

Onde:

$|\mathrm{AT}|=$ Taxa média do valor absoluto dos Accruals Totais;

$|\mathrm{FCO}|=$ Valor absoluto do fluxo de caixa operacional . 
A quarta medida (EM4) procura analisar a extensão com que os administradores gerenciam resultado para evitar reportar perdas. A respeito disso, Degeorge et al. (1999) e Burgstahler e Dichev (1997) evidenciaram que gerentes de empresas americanas têm fortes incentivos para evitar reportar declínio nos resultados. Contudo, embora a intenção pudesse ser evitar reportar perdas de qualquer magnitude, é limitada a capacidade de gerenciar resultados positivos na presença de grandes prejuízos. Dessa forma, a razão entre pequenos lucros e pequenos prejuízos reflete referida extensão, considerando-se que "pequenos lucros" estão no intervalo de $[0,0 ; 0,01]$ e "pequenos prejuízos" estão no intervalo de $[-0,01 ; 0,0]$. Ressalta-se que, consoante Leuz et al. (2002), seria necessário um número mínimo de observações de pequenas perdas para tornar a medida confiável.

$$
\mathrm{Em}_{4}=\text { PeqLuc } / \text { PeqPrej }
$$

Onde:

PeqLuc = Lucro líquido dividido pelos Ativos Totais em ( $\mathrm{t}-1)$;

PeqPrej = Lucro líquido dividido pelos Ativos Totais em ( $\mathrm{t}-1)$;

Adotada no estudo realizado por Gontcharov e Zimmerman (2003), após ser sugerida no estudo de Hung et al (1997) apud Pincus e Rajgopal (2002, p. 132), uma quinta medida (EM5) pode ser calculada e tem por finalidade verificar o efeito da norma contábil sobre o gerenciamento de resultados, apresentando o comportamento da variação do lucro nãodiscricionário em relação à variação do lucro líquido. Segundo Gontcharov e Zimmerman (2003, p. 11):

Quando o gerenciamento reduz a volatilidade dos lucros pelo uso dos accruals discricionários, o desvio padrão para o lucro líquido apresenta valores menores. Portanto, a volatilidade dos lucros antes dos accruals anormais ou discricionários maiores que a volatilidade do lucro líquido indica atividades de suavização dos lucros. Nesses casos, o quociente de suavização apresenta valores maiores que um. 
Dessa forma, a EM5, ou o quociente de suavização, é calculada da seguinte forma:

$$
E M_{5}=\sigma_{L N D_{i i}} / \sigma_{L L_{i i}}
$$

Onde:

$\sigma_{\mathrm{LND}}=$ Desvio-padrão do lucro não-discrionário dividido pelos Ativos Totais em ( $\mathrm{t}$-1);

$\sigma_{\mathrm{LL}}=$ Desvio-padrão do lucro líquido dividido pelos Ativos Totais em (t -1);

$\mathrm{i}=$ companhia.

Para cálculo da fórmula acima, faz-se necessário encontrar o valor do lucro não-discricionário que é calculado a seguir:

$$
L N D_{i}=F C O_{i}+A N D_{i}
$$

Onde:

LDN = Lucro não-discrionário;

FCO $=$ Fluxo de caixa das operações ${ }^{8}$;

AND = Accruals não-discrionários ${ }^{9}$;

$\mathrm{i}=$ companhia.

Como pode ser verificado nas fórmulas apresentadas, o cálculo dos accruals totais é de suma importância para a realização dos estudos. É possível encontrar os accruals totais pela diferença entre o lucro antes dos itens extraordinários e do fluxo de caixa operacional, ou ainda, por meio da mudança em sucessivas contas patrimoniais. Em muitos países, incluindo o Brasil, o fluxo de caixa não era uma demonstração obrigatória, tornando necessário calcular os accruals pelas diferenças no Balanço Patrimonial, técnica esta que foi utilizada nas pesquisas de Healy (1985), Jones (1991), Dechow et al (1995) e Sloan (1996) e que é abaixo reproduzida:

\footnotetext{
${ }^{8}$ Neste trabalho, serão computados indiretamente como a diferença entre o lucro operacional e os accruals totais;

${ }^{9}$ Neste trabalho, os accruals não-discricionários serão calculados pelo modelo modificado de Jones.
} 


$$
A T_{t}=\left(\Delta A C_{t}-\Delta P C_{t}-\Delta \text { Disp }_{t}+\Delta \text { FinEmp }_{t}-\text { Deprec }_{t}\right) / A_{t-1}
$$

Onde:

$\mathrm{AT}_{\mathrm{t}}=$ Accrual Total em $\mathrm{t}$

$\Delta \mathrm{AC}_{\mathrm{t}}=$ Variação no Ativo Circulante em $\mathrm{t}$;

$\Delta \mathrm{PC}_{\mathrm{t}}=$ Variação no Passivo Circulante em $\mathrm{t}$;

$\Delta$ Disp $_{\mathrm{t}}=$ Variação no Caixa e Equivalente a Caixa em $\mathrm{t}$;

$\Delta$ FinEmp $_{\mathrm{t}}=$ Variação em Financiamentos e Empréstimos de Curto Prazo em t;

$\Delta$ Deprec $_{\mathrm{t}}=$ Despesa de Depreciação e Amortização em t;

$\mathrm{A}_{\mathrm{t}-1}=$ Ativo Total em $(\mathrm{t}-1)$.

Ressalta-se que, embora o uso dos accruals totais como proxy para o gerenciamento de resultados pode ser um método bastante simplista, vários pesquisadores já demonstraram empiricamente que os accruals discricionários são uma proxy válida na verificação de gerenciamento de resultados.

Por fim, uma sexta medida pode ser calculada (EM6), similarmente a Leuz et al (2002), para mitigar erro de mensuração. Referida métrica, já reportada no início desta seção (denominada aggregate measure of earnings management) é calculada pela média das posições das medidas estruturadas, sendo que altos valores sugerem maiores níveis de gerenciamento de resultados.

\subsection{Evidências de gerenciamento de resultados}

Pontualmente, existem alguns relatos na literatura de ocorrências de gerenciamento de resultados ocorridos em grandes empresas, tais como Enron, WorldCom e Xerox, os quais culminaram nas mudanças significativas ocorridas na legislação, seja no Brasil ou no exterior, visando controlar este tipo de ocorrência. 
Resumidamente, um dos artifícios utilizados pela Enron foi não incluir nas demonstrações consolidadas suas centenas de SPEs fazendo com que passivos e prejuízos significativos fossem ocultados e deixando de evidenciar o verdadeiro risco da empresa.

Já a WorldCom lançou indevidamente despesas em contas de investimento de capital, buscando, assim, aumentar os lucros e, por conseqüência, conseguir obter empréstimos junto aos bancos.

A Xerox, por sua vez, contabilizou vendas e lucro irregulares quando lançou integralmente o aluguel, o financiamento e serviços de uma máquina como um valor único mensal, sendo que sua empresa de auditoria não fez nenhum tipo de ressalva em seu parecer.

No Brasil, por exemplo, Niero e Rocco (2000) citam o caso formado pelo grupo Eberle, Zivi e Hércules decorrente da adesão ao REFIS - Programa de Recuperação Fiscal, pelo qual os impostos vencidos até 31 de dezembro de 1999 foram absorvidos pelo programa. Assim, realizaram o cálculo de uma previsão de pagamento futuro de toda a dívida, sendo que o ajuste a valor presente afetou diretamente o resultado, aumentando o patrimônio líquido, além de transformar um prejuízo em lucro.

Além dos casos pontuais relatados acima, Martinez (2001) demonstrou que é possível evidenciar por meio de estudos empíricos, alguns indícios de gerenciamento de resultado no Brasil, conforme é relatado no quadro a seguir: 
Quadro 3 - Resultados sobre gerenciamento de resultados no Brasil

\begin{tabular}{|c|c|}
\hline Focos de Pesquisa & Resultados/(Evidências) \\
\hline $\begin{array}{l}\text { Hipótese } 1 \\
\text { "Gerenciamento" de Resultados para } \\
\text { Evitar Perdas }\end{array}$ & $\begin{array}{l}\text { a) Evita-se reportar perdas anuais e trimestrais; } \\
\text { b) Evita-se reportar resultados negativos de EBTDA( mas não no } \\
\text { EBITDA); } \\
\text { c) Evita-se reportar resultados negativos no lucro operacional e } \\
\text { LAIR; } \\
\text { d) Empresas endividadas têm maior propensão a "gerenciar" seus } \\
\text { resultados para evitar perdas. }\end{array}$ \\
\hline $\begin{array}{l}\text { Hipótese } 2 \\
\text { "Gerenciamento" de Resultados para } \\
\text { Sustentar o Desempenho Recente }\end{array}$ & $\begin{array}{l}\text { a) Fraca evidência de "gerenciamento" para assegurar a } \\
\text { continuidade dos resultados anuais e trimestrais; } \\
\text { b) Empresas com alto valor de mercado ( } M V / B V \text { ratio) têm maior } \\
\text { propensão ao "gerenciamento" de Resultados; } \\
\text { c) Algumas empresas podem estar praticando "gerenciamento" para } \\
\text { manter o LPA recente; } \\
\text { d) Empresas com seqüência de resultados positivos e crescente } \\
\text { acima do que seria probabilisticamente esperado. }\end{array}$ \\
\hline $\begin{array}{l}\text { Hipótese } 3 \\
\text { “Gerenciamento" de Resultados para } \\
\text { reduzir a Variabilidade dos } \\
\text { Resultados }\end{array}$ & $\begin{array}{l}\text { a) Contas de Depreciação, Despesas com Prov. Dev. Duvidosos e } \\
\text { receitas não Operacional ajudam na redução da variabilidade dos } \\
\text { resultados; } \\
\text { b) Variações do ativo diferido, amortização de ágio/deságio de } \\
\text { investimentos, provisão para perdas em investimentos podem estar } \\
\text { sendo utilizadas para reduzir variabilidade. }\end{array}$ \\
\hline $\begin{array}{l}\text { Hipótese } 4 \\
\text { "Gerenciamento" para manter } \\
\text { Credibilidade perante Credores }\end{array}$ & $\begin{array}{l}\text { a) Contas de Depreciação e recita não operacional ajudam a } \\
\text { minimizar resultados negativos; } \\
\text { b) Evidência da fig. } 4 \text {. }\end{array}$ \\
\hline $\begin{array}{l}\text { Hipótese } 5 \\
\text { "Gerenciamento" para piorar } \\
\text { resultados correntes em prol de } \\
\text { resultados futuros }\end{array}$ & $\begin{array}{l}\text { As empresas que, em média, possuíam a maior quantidade de } \\
\text { Acumulações discricionárias (discretionary accruals) negativas, } \\
\text { foram as empresas que possuíam, em termos médios, os maiores } \\
\text { prejuízos. }\end{array}$ \\
\hline $\begin{array}{c}\text { Hipótese } 6 \\
\text { Com o "Gerenciamento" de } \\
\text { Resultados no curto prazo o mercado } \\
\text { é ludibriado, porém no longo prazo o } \\
\text { mercado identifica o procedimento }\end{array}$ & $\begin{array}{l}\text { As empresas com os valores das acumulações discricionárias } \\
\text { (discretionary accrual) mais altas (positivas), bem como mais } \\
\text { baixas (negativas), tiveram desempenho, em termos de retornos } \\
\text { anormais médios, pior do que as outras empresas no longo prazo. }\end{array}$ \\
\hline $\begin{array}{l}\text { OUTROS RESULTADOS } \\
\text { Testando a Validade do modelo KS }\end{array}$ & $\begin{array}{l}\text { a) Empresas que lançam ADRs promovem o "gerenciamento" para } \\
\text { aumentar lucros um ano antes da emissão; } \\
\text { b) Entre 1996-1999, o ano de } 1999 \text { foi quando ocorreu a maior } \\
\text { prática do "gerenciamento"; } \\
\text { c) Em todos os setores ocorre certo "gerenciamento" dos resultados } \\
\text { contábeis, com destaque para Transportes Aéreos Construtoras e } \\
\text { Cimento. }\end{array}$ \\
\hline
\end{tabular}

Fonte: Martinez (2001, p. 121) 
Xie et al (2001), utilizando-se de análise quantitativa para gerenciamento de resultado e itens de governança corporativa, examinaram o relacionamento entre gerenciamento de resultados com a estrutura, o conhecimento técnico e a composição do conselho de administração, indicando que menores níveis de gerenciamento de resultados estão associados com a independência dos membros do conselho. Também identificaram que a presença de pessoas no conselho com experiência em investment banking estava associada à redução de gerenciamento de resultados. Por fim, os resultados também indicaram que quanto mais ativos os conselhos de administração e os comitês de auditoria, menores, também, os níveis de gerenciamento de resultados.

Estudo parecido foi desenvolvido por Carcello et al (2006) para o comitê de auditoria. Estes examinaram a associação entre a existência de especialistas no comitê de auditoria, mecanismos internos de governança corporativa e gerenciamento de resultados para trezentos e cinquienta empresas não-financeiras listadas na NYSE. As análises realizadas demonstraram que membros do comitê de auditoria com conhecimentos em contabilidade contribuem na redução do gerenciamento de resultado para empresas cujos mecanismos de governança corporativa encontram-se em patamares menores, contudo, a maior contribuição para menores níveis de earnings management pode ser verificada na presença do especialista em finanças.

Assim, conforme visto em todo o capítulo, o gerenciamento de resultados pode ser uma prática adequada quando utilizada pelos gestores para prover o mercado de informações mais realistas sobre a situação da empresa, contudo, em algumas ocasiões, o uso de accruals discrionários é utilizado de forma indevida com o intuito de ludibriar o mercado e de se obter algum favorecimento. É nesse momento que uma estrutura de governança corporativa, com adequado sistema de controles internos e riscos, deve adicionar valor à empresa e aos usuários de suas informações. 


\section{RESULTADOS EMPÍRICOS}

\subsection{Definições sobre a amostra}

Para a realização do estudo, foram coletados dados de todas as empresas listadas na BOVESPA durante os anos de 2002 a 2007. Os dados quantitativos, ou dados contábeis, foram extraídos da Economática ${ }^{\circledR}$ e os dados qualitativos, da CVM (sistema DIVEXT), site da BOVESPA e sites institucionais. A escolha do período em questão está relacionada com alguns fatores, tais como a comparabilidade dos dados pela estabilidade econômica advinda com o Plano Real e ser um período relacionado com a atualidade vivenciada pela BOVESPA, na qual é possível encontrar empresas já com as melhores práticas preconizadas pelo IBGC. Trata-se, assim, de uma amostragem por julgamento ou intencional, a qual, em algumas ocasiões, pode adicionar melhores resultados advindos do conhecimento do pesquisador sobre a população em análise, consoante Stevenson (1981, p. 167), nesses casos "[...] será melhor confiar no conhecimento da administração para fazer tal escolha.” O quadro a seguir demonstra os dados coletados: 
Quadro 4 - Variáveis utilizadas e sistemas para captura

\begin{tabular}{|c|c|}
\hline SISTEMA DE CAPTURA & VARIÁVEIS \\
\hline DIVEXT (CVM) & $\begin{array}{l}\text { Relacionadas ao conselho fiscal: } \\
\text { - Existência de conselho fiscal; } \\
\text { - Existência de presidente no conselho fiscal; } \\
\text { - Número de conselheiros; } \\
\text { - Formação dos conselheiros; } \\
\text { - Independência dos conselheiros; } \\
\text { - Número de reuniões. } \\
\text { Relacionadas ao conselho de administração: } \\
\text { - Presença do CEO no conselho de administração; } \\
\text { - Número de conselheiros independentes; } \\
\text { - Número de reuniões } \\
\text { Relacionadas ao controle acionário: } \\
\text { - Acionista majoritário; } \\
\text { - Administrador acionista; } \\
\text { - Investidor institucional. } \\
\text { Geral: } \\
\text { - Empresa de auditoria independente. }\end{array}$ \\
\hline Economática ${ }^{\circledR}$ & $\begin{array}{l}\text { - Setor econômico; } \\
\text { - Ativo Total; } \\
\text { - Lucro Operacional-EBIT; } \\
\text { - Ativo Circulante; } \\
\text { - Passivo Circulante; } \\
\text { - Disponível } \\
\text { - Clientes e Duplicatas a receber; } \\
\text { - Ativo Permanente; } \\
\text { - Despesa de Depreciação e Amortização; } \\
\text { - Valor de Mercado; } \\
\text { - Financiamento curto prazo }\end{array}$ \\
\hline Site da BOVESPA & - Segmentos de governança corporativa (Novo Mercado; Níveis 1 e 2). \\
\hline Sites institucionais & $\begin{array}{l}\text { - Emissão de ADRs (atendimento à lei Sarbanes Oxley); } \\
\text { - Existência de comitê de auditoria. }\end{array}$ \\
\hline
\end{tabular}

Utilizando-se da literatura e pesquisas acadêmicas sobre governança e gerenciamento de resultados apresentadas nos capítulos anteriores, foram identificadas as seguintes variáveis para compor a presente pesquisa: existência de conselho fiscal; existência de presidente no 
conselho fiscal; número, formação e independência dos conselheiros fiscais; número de reuniões do conselho fiscal; presença do CEO no conselho de administração; número de conselheiros de administração independentes; número de reuniões do conselho de administração; acionista majoritário; administrador acionista; investidor institucional; empresa de auditoria independente; segmentos de governança corporativa (Novo Mercado; Níveis 1 e 2); emissão de ADRs, American Depositary Receipts; existência de comitê de auditoria.

Tendo como base o Código das Melhores Práticas de Governança do IBGC, bem como as instruções contidas na Lei Sarbanes-Oxley, as variáveis relacionadas ao conselho de administração, conselho fiscal, comitê de auditoria e nível de governança perfazem a hipótese de empresas com melhor estrutura de governança e sistema de controles internos. É possível encontrar na literatura autores que utilizaram a mesma sistemática. Silveira (2002), por exemplo, empregou em seu estudo a composição do conselho de administração como hipótese de melhor governança corporativa. Liu (2005), por sua vez, testou a hipótese de melhores disclosures nos relatórios contábeis com a existência de comitê de auditoria.

Considerando-se que o conselho de administração tem como principal função monitorar o CEO (Jensen, 1993), haveria uma lacuna de independência caso o CEO fizesse parte de tal conselho. A respeito disso, Dechow et al (1996) encontraram relacionamento positivo entre violações nos princípios contábeis e empresas nas quais os CEOs faziam parte do conselho de administração. Por outro lado, algumas pesquisas, como por exemplo de Brickley et al (1994) e de Shivadasani (1993), também demonstraram que não apenas a presença do CEO pode diminuir a independência do conselho, mas também a presença de outros membros que tenham alguma ligação com a empresa. Ademais, Yermack (1996) verificou que conselhos de administração com um menor número de conselheiros tem maior probabilidade de eficiência no processo de monitoramento dos gestores.

Com relação ao comitê de auditoria, várias pesquisas internacionais têm sido realizadas relacionando-o a boas práticas de governança corporativa e/ou níveis de gerenciamento de resultados. Referidas pesquisas, de forma geral, versam sobre sua existência e independência, bem como sobre o conhecimento contábil ou financeiro de seus membros. Abbott et al (2004) e Bédard et al (2004) encontraram relacionamento entre empresas que apresentavam agressivo 
gerenciamento de resultado e não possuíam especialistas financeiro ${ }^{10}$ no comitê de auditoria. DeFond et al (2005) demonstraram, ainda, que existem dois níveis de especialistas financeiro, quer sejam, com formação contábil e sem formação contábil (mas com alguma experiência financeira), evidenciando que reportes contábeis de alta qualidade estão relacionados com o primeiro grupo de especialistas.

Dessa forma, em sendo o conselho fiscal o órgão de controle previsto na legislação brasileira, que teria funções de fiscalização até certo ponto similares ao comitê de auditoria, sendo inclusive aceito pela SEC como órgão a substituir referido comitê (desde que atendidos certos requisitos), definiu-se que as variáveis a serem testadas seriam as mesmas utilizadas na literatura estudada para o comitê de auditoria e conselho de administração.

A justificativa para a utilização das variáveis ADRs e adesão aos níveis de governança da Bovespa (nível 1 e 2 e Novo Mercado) deve-se ao fato de que empresas nessas condições teriam que se enquadrar a padrões mais rígidos de transparência e governança corporativa (SILVEIRA, 2004, p. 86).

Por fim, as variáveis 'acionista majoritário', 'administrador acionista' e 'investidor institucional' foram utilizadas uma vez que estudos demonstraram sua influência no processo de governança corporativa e nas práticas de gerenciamento de resultados. Shleifer e Vishny (1986) sugerem que a concentração em poucos acionistas controladores indicam um direcionamento de interesses, assim como a existência de administradores que também são acionistas (WARFIELD et al, 1995). Em contrapartida, conforme verificado por Rajpopal et al (1999), grandes números de investidores institucionais reduzem a incidência dos accruals discricionários.

Conforme relatado em capítulo anterior, o gerenciamento de resultados também pode ser afetado por elementos relacionados às características das empresas, como tamanho, nível de endividamento, valor de mercado entre outros. DeFond e Jiambalvo (1994), por exemplo, verificaram que gestores de empresas com altos níveis de endividamento têm incentivo para

\footnotetext{
${ }^{10}$ Definem como sendo especialista financeiro os membros do comitê de auditoria com CPA, investment banker, CFO, controller ou pessoas que tenham desempenhado funções com responsabilidades financeiras (CEO, VP, Presidente).
} 
aumentar os lucros, evitando-se possíveis quebras de contratos (covenants). Por conseguinte, as variáveis de controle utilizadas foram valor de mercado, o total de dívidas e o tamanho dos ativos.

Similarmente ao trabalho de Bradbury et al (2004) a variável 'valor de mercado' representa a relação entre o valor de mercado e o patrimônio líquido e o total das dívidas é representado em relação ao total de ativos. Foi utilizado o logaritmo natural do total do ativo para representar o tamanho da empresa, uma vez que pesquisas empíricas realizadas anteriormente indicaram que a qualidade dos accruals está positivamente relacionada ao seu logaritmo (DECHOW e DICHEV, 2002; DHALIWAL et al, 2006).

Ressalta-se, também, que para o cálculo dos níveis de gerenciamento de resultados, tanto pelo modelo de Jones (1991) quanto pelas métricas de Leuz et al (2002) é necessário que a amostra contenha apenas as empresas que apresentem todos os dados, para todos os anos. Dessa forma, a amostra final utilizada foi de 216 empresas para cada um dos anos analisados, já se considerando a eliminação dos 2,5\% superiores e inferiores com relação aos quartis (outliers). As variáveis utilizadas são resumidas no quadro a seguir: 
Quadro 5 - Variáveis utilizadas em toda a pesquisa

\begin{tabular}{|c|c|}
\hline VARIÁVEIS & DESCRIÇÃO \\
\hline COD_CVM & Código da empresa na Comissão de Valores Mobiliários - CVM. \\
\hline BIG_FOUR & $\begin{array}{l}\text { Variável binária: } 1 \text { se a empresa de auditoria for uma das big four e } 0 \text { caso } \\
\text { contrário. }\end{array}$ \\
\hline CF & Variável binária: 1 se a empresa possuir conselho fiscal e 0 caso contrário. \\
\hline PRES_CF & $\begin{array}{l}\text { Variável binária: } 1 \text { se a empresa possuir presidente no conselho fiscal e } 0 \text { caso } \\
\text { contrário. }\end{array}$ \\
\hline CAUD & Variável binária: 1 se a empresa possuir comitê de auditoria e 0 caso contrário. \\
\hline SOX & Variável binária: 1 se a empresa possuir $A D R s$ e 0 caso contrário. \\
\hline GOVERN & $\begin{array}{l}\text { Variável binária: } 1 \text { se a empresa tenha aderido aos níveis de governança da } \\
\text { Bovespa e } 0 \text { caso contrário. }\end{array}$ \\
\hline CEO & $\begin{array}{l}\text { Variável binária: } 1 \text { se o } C E O \text { fizer parte do conselho de administração e } 0 \text { caso } \\
\text { contrário. }\end{array}$ \\
\hline N_DIR_AD & Número de diretores no conselho de administração. \\
\hline P_DIR_AD & Percentual de diretores no conselho de administração. \\
\hline N_IND_AD & Número de membros independentes no conselho de administração. \\
\hline P_IND_AD & Percentual de membros independentes no conselho de administração. \\
\hline N_REU_AD & Número de reuniões do conselho de administração. \\
\hline TAM_AD & Tamanho do conselho de administração. \\
\hline TAM_CF & Tamanho do conselho fiscal. \\
\hline N_REU_CF & Número de reuniões do conselho fiscal. \\
\hline REU_CF & $\begin{array}{l}\text { Variável binária: } 1 \text { se o número de reuniões do conselho fiscal for igual ou maior } \\
\text { que dois e } 0 \text { caso contrário. }\end{array}$ \\
\hline N_IND_CF & $\begin{array}{l}\text { Número de membros independentes (sem ligações presentes ou passadas em } \\
\text { empresas ligadas ao grupo econômico) no conselho fiscal. }\end{array}$ \\
\hline P_IND_CF & Percentual de membros independentes no conselho fiscal. \\
\hline EXP_CF & $\begin{array}{l}\text { Variável binária: } 1 \text { se a empresa possuir pelo menos um membro no conselho fiscal } \\
\text { com formação em ciências contábeis e } 0 \text { caso contrário. }\end{array}$ \\
\hline P_EXP_CF & Percentual de membros no conselho fiscal com formação em ciências contábeis. \\
\hline ACION_MAJOR & $\begin{array}{l}\text { Variável binária: } 1 \text { se a empresa possuir um acionista com cinqüenta por cento ou } \\
\text { mais das ações ordinárias e } 0 \text { caso contrário. }\end{array}$ \\
\hline DIR_MAJOR & $\begin{array}{l}\text { Variável binária: } 1 \text { se a empresa possuir diretores acionistas com cinqüenta por } \\
\text { cento ou mais das ações ordinárias e } 0 \text { caso contrário. }\end{array}$ \\
\hline INSTITUC & Percentual de investidores institucionais. \\
\hline ATIVO & Total do ativo. \\
\hline LN_AT & Logaritmo natural do ativo total. \\
\hline DIV_AT & Total de dívidas dividido pelo total de ativo. \\
\hline DIV_PL & Total de dívidas dividido pelo patrimônio líquido. \\
\hline VM_PL & Valor de mercado dividido pelo patrimônio líquido. \\
\hline AD & $\begin{array}{l}\text { Valor do accrual discricionário calculado pelo modelo de Jones (1991), conforme } \\
\text { demonstrado no capítulo } 4 .\end{array}$ \\
\hline EM1 & $\begin{array}{l}\text { Métrica de gerenciamento de resultado de Leuz et al (2002) conforme demonstrado } \\
\text { no capítulo } 4 \text {. }\end{array}$ \\
\hline EM2 & $\begin{array}{l}\text { Métrica de gerenciamento de resultado de Leuz et al (2002) conforme demonstrado } \\
\text { no capítulo } 4 \text {. }\end{array}$ \\
\hline EM3 & $\begin{array}{l}\text { Métrica de gerenciamento de resultado de Leuz et al (2002) conforme demonstrado } \\
\text { no capítulo } 4 \text {. }\end{array}$ \\
\hline EM5 & $\begin{array}{l}\text { Métrica de gerenciamento de resultado de Leuz et al (2002) conforme demonstrado } \\
\text { no capítulo } 4 \text {. }\end{array}$ \\
\hline EM6 & $\begin{array}{l}\text { Métrica de gerenciamento de resultado de Gontcharov e Zimmerman (2003) } \\
\text { conforme demonstrado no capítulo } 4 \text {. }\end{array}$ \\
\hline
\end{tabular}


Quadro 5 (continuação)

\begin{tabular}{|c|c|}
\hline \multirow[b]{2}{*}{ VARIÁVEIS } & \\
\hline & DESCRIÇÃO \\
\hline EM1_2 & Métrica de gerenciamento de resultado conforme demonstrado no capítulo 4. \\
\hline BCGI $^{11}$ & $\begin{array}{l}\text { Brazilian Corporate Governance Index (Lopes, 2008). Índice composto por quarto } \\
\text { componentes de governança corporativa: disclosure, composição do board, } \\
\text { estrutura de capital e controle, direito dos acionistas. }\end{array}$ \\
\hline EVID & Disclosure (Lopes, 2008). \\
\hline COMP_BD & Composição do board (Lopes, 2008). \\
\hline PROP_CN & Estrutura de propriedade e controle (Lopes, 2008). \\
\hline DIR_AC & Direito dos acionistas (Lopes, 2008). \\
\hline CF_EXP & $\begin{array}{l}\text { Representa o efeito da existência de conselho fiscal com a existência de especialista } \\
\text { em ciências contábeis (multiplicação das duas variáveis). }\end{array}$ \\
\hline CF_PRESID & $\begin{array}{l}\text { Representa o efeito da existência de conselho fiscal com a existência de presidente } \\
\text { no referido conselho (multiplicação das duas variáveis). }\end{array}$ \\
\hline EXP_GOV & $\begin{array}{l}\text { Representa o efeito da existência de especialista em ciências contábeis no conselho } \\
\text { fiscal e de nível de governança corporativa Bovespa (multiplicação das duas } \\
\text { variáveis). }\end{array}$ \\
\hline LOSS & Variável binária: 1 se a empresa teve prejuízo no ano anterior e 0 caso contrário. \\
\hline
\end{tabular}

Foram realizadas regressões lineares simples, análise de dados em painel e análise de clusters, nas quais as variáveis dependentes foram representadas pelas métricas de gerenciamento de resultados e as variáveis independentes representaram-se pelos componentes de governança corporativa e variáveis de controle, sendo as hipóteses testadas em termos dos coeficientes encontrados.

Em termos esquemáticos, é possível dividir a análise em duas grandes etapas: cálculo e análise das métricas de Leuz et al (2002) com as variáveis de governança corporativa por meio de clusters e regressão simples; e cálculo e aplicação do modelo de Jones (1991) em dados em painel para comprovação dos resultados encontrados. A seguir, as etapas são detalhadas.

${ }^{11}$ O BCGI (Brazilian Corporate Governance Index) foi calculado por Lopes (2008) em sua tese de doutorado na University of Manchester, tendo como base o estudo de Carvalhal-da-Silva e Leal (2005). Foi construído por meio de um questionário contendo quinze itens e aplicado a todas as empresas listadas na Bovespa. Está estruturado em quatro componentes: disclosure, composição do board, estrutura de propriedade e direito dos acionistas. As respostas ao questionário são binárias, sendo que o 1 representa boa governança. $\mathrm{O}$ índice é calculado como a média dos quatro componentes. Nesta tese, utilizou-se tanto o índice como seus componentes individualmente. 


\subsection{Análise estatística dos resultados - métricas de Leuz et al (2002)}

As métricas de Leuz et al (2002) foram calculadas para cada uma das empresas, assim como as demais variáveis, em uma série temporal. Em seguida, foram consideradas suas médias para composição da base de regressões. A estatística descritiva das variáveis estudadas aparece na tabela 1 .

Ademais, por ser o conselho fiscal o ponto central desta pesquisa quanto ao controle do gerenciamento de resultados contábeis, na tabela 2 e gráfico 1 são demonstradas as frequiências de sua ocorrência, bem como a distribuição em especialistas em ciências contábeis. 
Tabela 1- Estatística descritiva

\begin{tabular}{|c|c|c|c|c|c|}
\hline VARIÁVEIS & $\mathbf{N}$ & MINIMUM & MAXIMUM & MEAN & $\begin{array}{c}\text { STD. } \\
\text { DEVIATION }\end{array}$ \\
\hline BIG_FOUR & 216 & 00 & 1,00 & ,5718 & ,4371 \\
\hline $\mathrm{CF}$ & 216 & 00 & 1,00 & ,5455 & ,3603 \\
\hline PRES_CF & 216 &, 00 &, 83 & , 1003 & 2244 \\
\hline CAUD & 216 & ,00 & 1,00 & $6,327 \mathrm{E}-02$ & 1779 \\
\hline SOX & 216 &, 00 &, 50 & $3,009 \mathrm{E}-02$ & $9,906 \mathrm{E}-02$ \\
\hline GOVERN & 216 & ,00 & 3,00 & ,2160 & ,4909 \\
\hline CEO & 216 &, 00 & 1,83 & ,6204 & ,4243 \\
\hline N_DIR_AD & 216 & ,00 & 2,67 & ,4236 & ,5730 \\
\hline P_DIR_AD & 216 & 00 &, 40 & $6,570 \mathrm{E}-02$ & $9,126 \mathrm{E}-02$ \\
\hline N_IND_AD & 216 & ,83 & 24,83 & 6,5594 & 4,3602 \\
\hline P_IND_AD & 216 & 28 & 1,06 & 8106 &, 1385 \\
\hline N_REU_AD & 216 &, 00 & 21,83 & 3,5525 & 3,0439 \\
\hline REU_AD & 216 &, 00 &, 83 & $3,935 \mathrm{E}-02$ &, 1240 \\
\hline TAM_AD & 216 & 2,00 & 24,83 & 7,6466 & 4,2918 \\
\hline TAM_CF & 216 &, 00 & 10,00 & 4,0648 & 2,9996 \\
\hline N_REU_CF & 216 & ,00 & 3,83 & ,2323 & 6691 \\
\hline REU_CF & 216 & ,00 & 83 & $3,858 \mathrm{E}-02$ & 1449 \\
\hline N_IND_CF & 216 & ,00 & 10,00 & 1,9985 & 2,6804 \\
\hline P_IND_CF & 216 & 00 & 1,00 & ,2645 & ,3363 \\
\hline EXP_CF & 216 & ,00 & 1,00 & ,2685 & ,3564 \\
\hline P_EXP_CF & 216 & 00 & ,73 & , 1017 & 1555 \\
\hline ACION_MAJOR & 216 &, 00 &, 50 & , 2160 & , 2160 \\
\hline DIR_MAJOR & 216 &, 00 &, 50 & $5,170 \mathrm{E}-02$ &, 1402 \\
\hline INSTITUC & 216 & ,00 & 50,00 & 3,0756 & 8,9865 \\
\hline ATIVO & 216 & 6,33 & 263472808,00 & 6813648,9922 & 28247672,4498 \\
\hline LN_AT & 216 & ,87 & 19,37 & 13,3182 & 2,2813 \\
\hline DIV_AT & 216 &,- 76 & 34,32 & ,3782 & 2,3911 \\
\hline DIV_PL & 216 & $-5,42$ & 97,69 & 1,5098 & 9,4380 \\
\hline VM_PL & 216 & $-2,63$ & 19,55 & 1,4775 & 2,4244 \\
\hline EM1 & 216 & ,00 & 2,07 & ,6186 & ,3805 \\
\hline EM2 & 216 & $-1,00$ & 41 &,- 8431 & ,2201 \\
\hline EM3 & 216 & ,01 & 9,75 & ,7476 & 1,2168 \\
\hline EM5 & 216 & ,07 & 16,47 & 2,7573 & 2,7819 \\
\hline EM6 & 216 & 33,50 & 187,50 & 118,9572 & 28,5751 \\
\hline BCGI & 216 &, 00 &, 73 & ,3574 & ,1349 \\
\hline EVID & 216 & ,00 & 1,00 & ,5195 & ,2201 \\
\hline COM_BD & 216 & , 13 & ,93 & ,5213 & 1837 \\
\hline PROP_CN & 216 & , 00 & ,92 & ,3364 & ,2292 \\
\hline DIR_AC & 216 & 00 & 1,00 & $7,870 \mathrm{E}-02$ & ,1661 \\
\hline CF_EXP & 216 &, 00 & 1,00 & ,2157 & ,2965 \\
\hline EXP_GOV & 216 &, 00 & 1,39 & $8,423 \mathrm{E}-02$ & ,2402 \\
\hline EM1_2 & 216 & 4,50 & 216,00 & 108,5000 & 59,1965 \\
\hline
\end{tabular}


Tabela 2 - Distribuição de freqüências: conselho fiscal e especialista contábil

\begin{tabular}{|c|c|c|c|c|c|c|c|}
\hline \multicolumn{4}{|c|}{} & \multicolumn{4}{c|}{ EXP_CF } \\
\hline $\mathbf{N}^{\mathbf{0}}$ & Frequency & Percent & $\begin{array}{c}\text { Cumulative } \\
\text { Percent }\end{array}$ & $\mathbf{N}^{\mathbf{0}}$ & Frequency & Percent & $\begin{array}{c}\text { Cumulative } \\
\text { Percent }\end{array}$ \\
\hline, 00 & 56 & 25,9 & 25,9 &, 00 & 129 & 59,7 & 59,7 \\
\hline, 17 & 6 & 2,8 & 28,7 &, 17 & 5 & 2,3 & 62,0 \\
\hline, 33 & 9 & 4,2 & 32,9 &, 33 & 12 & 5,6 & 67,6 \\
\hline, 50 & 11 & 5,1 & 38,0 &, 50 & 9 & 4,2 & 71,8 \\
\hline, 67 & 24 & 11,1 & 49,1 &, 67 & 14 & 6,5 & 78,2 \\
\hline, 83 & 106 & 49,1 & 98,1 &, 83 & 46 & 21,3 & 99,5 \\
\hline 1,00 & 4 & 1,9 & 100,0 & 1,00 & 1 &, 5 & 100,0 \\
\hline Total & 216 & 100,0 & & Total & 216 & 100,0 & \\
\hline
\end{tabular}

Esta tabela contém a distribuição de freqüências do conselho fiscal e especialista em ciências contábeis em percentuais com relação aos anos estudados (2002-2007).

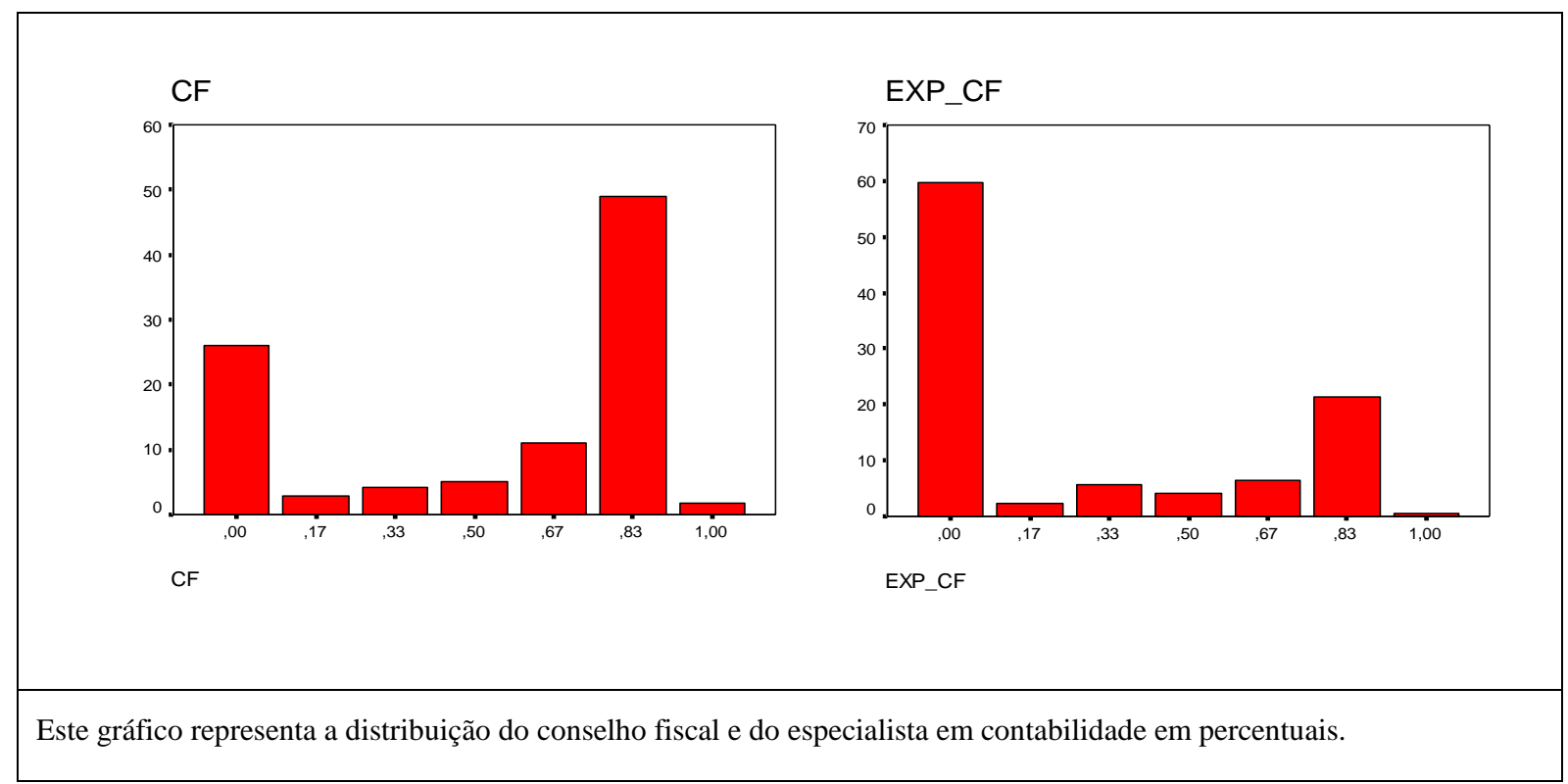

Gráfico 1 - Distribuição percentual - conselho fiscal e especialista contábil

Verifica-se pela tabela 2 que 56 empresas (aproximadamente 26\%) não apresentaram conselho fiscal em nenhum dos anos estudados, e apenas 4 empresas (aproximadamente 2\%) apresentarem conselho fiscal em todos os anos. Contudo, ressalta-se que quase $50 \%$ das empresas tinham conselho fiscal estabelecido em cinco dos seis anos analisados. A existência de profissionais em ciências contábeis nos conselhos fiscais representou $21 \%$ dos conselhos em cinco anos analisados, sendo que apenas uma empresa possuía o especialista em todos os anos. Realmente, diferentemente das normas estudadas nesta tese para o comitê de auditoria, que exigem na composição do referido comitê a existência de especialistas financeiros e contábeis, a lei para o conselho fiscal não faz nenhum tipo de exigência sobre a formação dos 
conselheiros fiscais, apenas sobre a composição e representação de acionistas minoritários e majoritários. Por conseguinte, o que se verifica é a não preocupação quanto ao tema "formação dos conselheiros" na composição de conselho fiscal.

Na tabela 3, apresentam-se os cálculos das métricas de gerenciamento de resultados para cada uma das empresas da amostra, sendo que a classificação foi realizada levando-se em consideração a variável EM6, a qual fornece uma média quanto às demais métricas. Ressaltase que a variável EM1_2 representa a média de gerenciamento de resultados apenas para as variáveis EM1 e EM2, as quais indicam a suavização e variabilidade dos lucros reportados e serão detalhadas à frente. 
Tabela 3 - Métricas de gerenciamento de resultados para cada empresa (classificadas por EM6)

\begin{abstract}
As variáveis foram calculadas para 1.206 observações para os anos de 2002 a 2007. EM1 é calculada pelo desvio-padrão do lucro operacional pelo desvio padrão do fluxo de caixa operacional (ambos divididos pelo total de ativos). O fluxo de caixa operacional é calculado indiretamente pela diferença entre o lucro operacional e os accruals totais. EM2 representa a correlação das variações dos accruals totais com as variações do fluxo de caixa operacional (ambos divididos pelos ativos totais). EM3 é a taxa média dos valores absolutos dos accruals e o valor absoluto do fluxo de caixa operacional. EM5 é calculada pelo desvio padrão do lucro não discricionário pelo desvio padrão do lucro líquido (ambos divididos pelos ativos totais). O lucro não discricionário é a somatória do fluxo de caixa operacional e os accruals não discricionários, sendo estes calculados pelo modelo modificado de Jones (1991). EM6 (aggregate earnings management score) representa a média das quatro métricas (EM1, EM2, EM3 e EM5) e EM1_2 representa a média das duas primeiras métricas. EM4 não foi calculada pois seriam necessários, no mínimo, cinco observações de 'pequenos lucros' para cada empresa na amostra (LEUZ et al, 2002, p. 9). Os sinais nas colunas indicam se altos valores para as respectivas métricas implicam em maiores $(+)$ ou menores (-) gerenciamento de resultados.
\end{abstract}

\begin{tabular}{|c|c|c|c|c|c|c|c|}
\hline $\begin{array}{c}\text { CÓDIGO } \\
\text { CVM }\end{array}$ & SETOR ECONÔMICO & $\begin{array}{l}\text { EM1 } \\
(-)\end{array}$ & $\begin{array}{c}\text { EM2 } \\
(-)\end{array}$ & $\begin{array}{c}\text { EM3 } \\
(+)\end{array}$ & $\begin{array}{c}\text { EM5 } \\
(+)\end{array}$ & EM6 & EM1_2 \\
\hline 13781 & Outros & 0.5063 & -0.9921 & 0.1286 & 0.4932 & 187.50 & 154.50 \\
\hline 14761 & Têxtil & 0.3297 & -0.9784 & 0.1285 & 0.7984 & 184.50 & 159.50 \\
\hline 16497 & Têxtil & 0.0869 & -0.9994 & 0.8916 & 0.4626 & 181.50 & 208.50 \\
\hline 14443 & Outros & 0.3498 & -0.9944 & 0.2634 & 0.8157 & 180.25 & 176.50 \\
\hline 7978 & Outros & 0.2808 & -0.9689 & 0.1656 & 0.8562 & 176.50 & 157.50 \\
\hline 6343 & Veículos e peças & 0.1994 & -0.9959 & 0.2410 & 1.6172 & 173.75 & 194.00 \\
\hline 18350 & Energia Elétrica & 0.6336 & -0.9957 & 0.0381 & 1.5032 & 168.00 & 146.00 \\
\hline 4774 & Construção & 0.1199 & -0.9924 & 0.0352 & 5.7303 & 167.75 & 193.00 \\
\hline 108 & Siderurgia \& Metalurgia & 0.2375 & -0.9924 & 0.1441 & 2.4418 & 167.50 & 184.00 \\
\hline 5770 & Outros & 0.2367 & -0.9788 & 0.3786 & 0.9201 & 164.25 & 169.00 \\
\hline 2860 & Petróleo e Gás & 0.2452 & -0.9910 & 0.1005 & 3.0665 & 164.00 & 177.00 \\
\hline 3174 & Transporte Serviço & 0.0216 & -0.9986 & 0.8985 & 1.3942 & 163.25 & 209.00 \\
\hline 13285 & Alimentos e Bebidas & 0.1419 & -0.9928 & 0.1509 & 3.4395 & 163.25 & 193.00 \\
\hline 16608 & Energia Elétrica & 0.5054 & -0.9954 & 0.3659 & 0.8858 & 162.75 & 161.50 \\
\hline 4057 & Outros & 0.6225 & -0.9531 & 0.0260 & 1.2117 & 158.75 & 112.50 \\
\hline 8117 & Comércio & 0.2143 & -0.9795 & 1.2099 & 0.3687 & 158.00 & 171.00 \\
\hline 11070 & Petróleo e Gás & 0.3659 & -0.9775 & 0.4360 & 0.8018 & 158.00 & 153.50 \\
\hline 6017 & Siderurgia \& Metalurgia & 0.5944 & -0.9911 & 0.0203 & 2.2400 & 157.75 & 142.50 \\
\hline 5410 & Máquinas Indust. & 0.5239 & -0.9077 & 0.0169 & 1.1986 & 157.50 & 107.00 \\
\hline 14605 & Energia Elétrica & 0.5594 & -0.9456 & 0.2175 & 0.6061 & 156.75 & 116.50 \\
\hline 16535 & Energia Elétrica & 0.3304 & -0.9664 & 0.2792 & 1.2885 & 156.25 & 153.00 \\
\hline 15695 & Outros & 0.4264 & -0.9238 & 0.2608 & 0.6836 & 155.25 & 121.50 \\
\hline 16527 & Energia Elétrica & 0.3361 & -0.9705 & 0.3622 & 1.0825 & 155.00 & 153.50 \\
\hline 3891 & Finanças e Seguros & 0.0957 & -0.9974 & 0.1770 & 16.4741 & 154.50 & 204.50 \\
\hline 14621 & Outros & 0.3751 & -0.9657 & 0.5244 & 0.5858 & 153.50 & 146.00 \\
\hline 8087 & Comércio & 0.3906 & -0.9906 & 0.0211 & 4.5449 & 153.00 & 159.50 \\
\hline 5150 & Veículos e peças & 0.1170 & -0.9985 & 0.7836 & 1.8039 & 152.25 & 204.00 \\
\hline 18848 & Alimentos e Bebidas & 0.1160 & -0.9916 & 0.1653 & 10.6822 & 151.25 & 192.50 \\
\hline 15865 & Outros & 0.9367 & -0.9758 & 0.0366 & 1.0704 & 150.00 & 92.50 \\
\hline 15881 & Veículos e peças & 0.3713 & -0.9911 & 0.7820 & 0.9191 & 149.25 & 165.00 \\
\hline 6041 & Outros & 0.0225 & -1.0000 & 0.9187 & 2.7880 & 148.25 & 213.00 \\
\hline 1155 & Finanças e Seguros & 0.1184 & -0.9995 & 0.3556 & 8.2696 & 147.00 & 207.00 \\
\hline 16730 & Energia Elétrica & 0.0227 & -1.0000 & 0.6318 & 3.9870 & 146.75 & 212.00 \\
\hline 17450 & Transporte Serviço & 0.2699 & -0.9879 & 0.2617 & 3.0042 & 146.75 & 171.00 \\
\hline 14362 & Energia Elétrica & 0.7700 & -0.9031 & 0.0963 & 0.8460 & 146.75 & 81.50 \\
\hline 4030 & Siderurgia \& Metalurgia & 0.3869 & -0.9231 & 0.1421 & 1.7660 & 146.50 & 125.50 \\
\hline 9512 & Petróleo e Gás & 0.5918 & -0.9771 & 0.1462 & 1.7994 & 146.25 & 129.00 \\
\hline 5991 & Têxtil & 1.1307 & -0.9712 & 0.1475 & 0.5831 & 146.00 & 81.00 \\
\hline
\end{tabular}


Tabela 3 (continuação)

\begin{tabular}{|c|c|c|c|c|c|c|c|}
\hline $\begin{array}{c}\text { CÓDIGO } \\
\text { CVM }\end{array}$ & SETOR ECONÔMICO & $\begin{array}{c}\text { EM1 } \\
(-)\end{array}$ & $\begin{array}{c}\text { EM2 } \\
(-)\end{array}$ & $\begin{array}{c}\text { EM3 } \\
(+)\end{array}$ & $\begin{array}{c}\text { EM5 } \\
(+)\end{array}$ & EM6 & EM1_2 \\
\hline 4782 & Construção & 0.0198 & -1.0000 & 1.2005 & 2.8323 & 145.75 & 214.50 \\
\hline 12530 & Eletroeletrônicos & 0.3262 & $\begin{array}{l}-0.9105 \\
\end{array}$ & 0.1156 & 2.2666 & 145.50 & 132.00 \\
\hline 14176 & Energia Elétrica & 0.4115 & -0.9460 & 0.2367 & 1.4803 & 145.50 & 133.00 \\
\hline 5274 & Outros & 0.4622 & -0.9919 & 0.1850 & 2.6545 & 145.50 & 157.00 \\
\hline 4448 & Veículos e peças & 0.0028 & -1.0000 & 0.9644 & 3.4067 & 144.50 & 216.00 \\
\hline 10588 & Eletroeletrônicos & 0.5566 & -0.7801 & 0.0818 & 0.9903 & 144.00 & 83.50 \\
\hline 5312 & Siderurgia \& Metalurgia & 0.5349 & -0.8751 & 0.3208 & 0.4551 & 143.75 & 99.50 \\
\hline 1023 & Finanças e Seguros & 0.0857 & -0.9989 & 0.4540 & 10.7740 & 142.25 & 208.50 \\
\hline 18112 & Alimentos e Bebidas & 0.1815 & -0.9948 & 0.4168 & 4.0921 & 142.00 & 193.50 \\
\hline 3549 & Têxtil & 0.2461 & -0.9987 & 1.8118 & 1.5565 & 141.75 & 192.00 \\
\hline 8192 & Outros & 0.3791 & -0.9841 & 0.6494 & 1.2621 & 140.25 & 155.50 \\
\hline 9083 & Máquinas Indust. & 0.3117 & -0.9955 & 1.8904 & 1.4379 & 139.75 & 183.50 \\
\hline 13412 & Outros & 0.9117 & -0.9531 & 0.0584 & 1.3706 & 139.75 & 85.50 \\
\hline 18279 & Agro e Pesca & 0.6157 & -0.8210 & 0.1000 & 1.0623 & 139.50 & 79.00 \\
\hline 18627 & Outros & 0.8107 & -0.9818 & 0.1527 & 1.5447 & 139.00 & 109.00 \\
\hline 9784 & Química & 0.3630 & -0.9550 & 0.3857 & 1.5542 & 138.25 & 143.50 \\
\hline 2100 & Têxtil & 0.4190 & -0.9635 & 1.0101 & 0.6704 & 138.25 & 140.00 \\
\hline 11231 & Siderurgia \& Metalurgia & 0.5202 & -0.9277 & 0.0305 & 2.5642 & 138.25 & 113.50 \\
\hline 18368 & Energia Elétrica & 0.4536 & -0.8960 & 0.2875 & 1.1664 & 137.00 & 111.50 \\
\hline 5762 & Minerais não Met. & 0.3389 & -0.9755 & 0.2257 & 3.7615 & 136.50 & 154.50 \\
\hline 13447 & Outros & 0.8231 & -0.7601 & 0.0568 & 0.7652 & 136.25 & 53.50 \\
\hline 2062 & Alimentos e Bebidas & 0.3706 & -0.9377 & 2.5415 & 0.0732 & 135.75 & 134.00 \\
\hline 17213 & Telecomunicações & 0.2305 & -0.9943 & 0.5204 & 4.0785 & 135.00 & 189.50 \\
\hline 15423 & Telecomunicações & 0.3215 & -0.9871 & 0.6261 & 1.8394 & 134.75 & 166.00 \\
\hline 4820 & Química & 0.3782 & -0.9432 & 0.4006 & 1.4751 & 134.75 & 133.50 \\
\hline 18309 & Energia Elétrica & 0.7903 & -0.8823 & 0.2312 & 0.6122 & 134.75 & 75.50 \\
\hline 5479 & Siderurgia \& Metalurgia & 0.5975 & -0.9336 & 0.2503 & 1.4115 & 134.25 & 108.00 \\
\hline 11398 & Química & 0.8884 & -0.9577 & 0.1555 & 1.2790 & 134.25 & 89.50 \\
\hline 11320 & Telecomunicações & 0.5980 & -0.9987 & 0.4543 & 2.1707 & 134.00 & 155.50 \\
\hline 13854 & Outros & 0.2939 & -0.9778 & 2.6070 & 1.0787 & 133.75 & 162.00 \\
\hline 8575 & Veículos e peças & 0.5681 & -0.9598 & 0.1799 & 2.1726 & 133.75 & 122.50 \\
\hline 8540 & Finanças e Seguros & 0.1351 & -0.9965 & 0.5051 & 10.1965 & 133.75 & 200.00 \\
\hline 14826 & Comércio & 0.2410 & -0.9838 & 0.3364 & 4.9003 & 133.50 & 171.00 \\
\hline 434 & Papel e Celulose & 0.7789 & -0.8698 & 0.2235 & 0.6393 & 133.00 & 72.00 \\
\hline 15377 & Outros & 0.0172 & -0.9998 & 1.2261 & 7.6260 & 132.50 & 213.50 \\
\hline 1104 & Finanças e Seguros & 0.2988 & -0.9770 & 1.3471 & 1.2824 & 132.25 & 160.00 \\
\hline 14931 & Outros & 0.3680 & -0.9616 & 0.1456 & 9.1408 & 131.75 & 145.50 \\
\hline 16390 & Transporte Serviço & 0.7528 & -0.9130 & 0.1745 & 1.2370 & 131.25 & 85.50 \\
\hline 8605 & Siderurgia \& Metalurgia & 0.5209 & -0.9352 & 0.2731 & 1.6520 & 131.00 & 116.50 \\
\hline 10456 & Têxtil & 0.5785 & -0.9440 & 0.0662 & 3.4366 & 131.00 & 113.50 \\
\hline 1198 & Finanças e Seguros & 0.3328 & -0.9698 & 0.3480 & 3.2603 & 130.00 & 153.50 \\
\hline 8818 & Comércio & 0.2459 & -0.9831 & 0.5024 & 3.2287 & 130.00 & 169.00 \\
\hline 8893 & Outros & 0.3235 & -0.9876 & 0.3404 & 5.3814 & 130.00 & 167.00 \\
\hline 7510 & Máquinas Indust. & 0.4373 & -0.9548 & 0.2132 & 3.1432 & 130.00 & 133.00 \\
\hline 4707 & Outros & 0.0401 & -0.9995 & 1.3159 & 7.8753 & 129.25 & 210.00 \\
\hline 18414 & Outros & 0.2580 & -0.9927 & 0.6068 & 3.8056 & 129.00 & 182.00 \\
\hline 6513 & Construção & 0.5383 & -0.9425 & 1.0043 & 0.5012 & 129.00 & 116.00 \\
\hline
\end{tabular}


Tabela 3 (continuação)

\begin{tabular}{|c|c|c|c|c|c|c|c|}
\hline $\begin{array}{c}\text { CÓDIGO } \\
\text { CVM }\end{array}$ & SETOR ECONÔMICO & $\begin{array}{c}\text { EM1 } \\
(-)\end{array}$ & $\begin{array}{c}\text { EM2 } \\
(-)\end{array}$ & $\begin{array}{c}\text { EM3 } \\
(+)\end{array}$ & $\begin{array}{c}\text { EM5 } \\
(+)\end{array}$ & EM6 & EM1_2 \\
\hline 2909 & Alimentos e Bebidas & 0.2591 & -0.9893 & 0.3488 & 7.9816 & 128.75 & 172.50 \\
\hline 12653 & Papel e Celulose & 0.6712 & -0.8876 & 0.3211 & 0.8536 & 128.50 & 86.50 \\
\hline 2488 & Minerais não Met. & 0.1647 & -0.9911 & 1.8362 & 2.2622 & 128.25 & 185.00 \\
\hline 4723 & Construção & 0.1504 & -0.9916 & 0.6015 & 6.3105 & 127.75 & 189.00 \\
\hline 13030 & Construção & 0.1135 & -0.9975 & 1.1022 & 6.0403 & 127.50 & 204.50 \\
\hline 10472 & Outros & 0.9242 & -0.9305 & 0.0288 & 1.7847 & 127.25 & 73.00 \\
\hline 13773 & Minerais não Met. & 0.4583 & -0.9649 & 0.3369 & 2.4716 & 126.50 & 136.00 \\
\hline 5258 & Comércio & 0.4898 & -0.9272 & 0.1583 & 3.2664 & 125.75 & 117.50 \\
\hline 2577 & Energia Elétrica & 0.7706 & -0.8409 & 0.3635 & 0.1545 & 125.75 & 67.00 \\
\hline 14524 & Energia Elétrica & 0.6146 & -0.9342 & 0.2154 & 1.9719 & 125.25 & 105.50 \\
\hline 17701 & Telecomunicações & 0.2332 & -0.9902 & 0.5761 & 4.9537 & 124.50 & 178.00 \\
\hline 14206 & Finanças e Seguros & 0.1350 & -0.9940 & 0.6937 & 11.7589 & 124.25 & 195.50 \\
\hline 14028 & Química & 0.4081 & -0.9570 & 0.2673 & 3.9271 & 124.00 & 138.00 \\
\hline 18465 & Química & 0.3501 & -0.8526 & 0.0133 & 13.7071 & 123.50 & 114.00 \\
\hline 18821 & Transporte Serviço & 0.6346 & -0.9181 & 0.2804 & 1.4683 & 123.50 & 96.50 \\
\hline 11762 & Têxtil & 0.6461 & -0.8516 & 0.3395 & 0.8697 & 123.50 & 80.00 \\
\hline 1970 & Eletroeletrônicos & 0.4290 & -0.9453 & 0.5110 & 1.7106 & 122.50 & 129.00 \\
\hline 9415 & Outros & 0.1969 & -0.9913 & 0.7997 & 5.0084 & 122.25 & 184.50 \\
\hline 3069 & Siderurgia \& Metalurgia & 1.2593 & -0.5265 & 0.0157 & 0.6282 & 122.25 & 16.00 \\
\hline 1309 & Finanças e Seguros & 0.5522 & -0.8751 & 0.1462 & 2.5255 & 122.00 & 98.00 \\
\hline 16292 & Alimentos e Bebidas & 0.7900 & -0.6873 & 0.0373 & 1.3953 & 122.00 & 51.00 \\
\hline 7447 & Siderurgia \& Metalurgia & 0.4210 & -0.9583 & 1.3799 & 1.2473 & 121.25 & 137.50 \\
\hline 2429 & Papel e Celulose & 0.6105 & -0.8980 & 0.3201 & 1.4525 & 121.25 & 95.50 \\
\hline 574 & Outros & 0.9090 & -0.9715 & 0.4718 & 1.0311 & 121.00 & 95.50 \\
\hline 9393 & Siderurgia \& Metalurgia & 0.4981 & -0.9873 & 0.6037 & 2.2718 & 120.75 & 146.50 \\
\hline 1120 & Finanças e Seguros & 0.1634 & -0.9929 & 0.7783 & 12.1611 & 120.50 & 192.00 \\
\hline 9989 & Petróleo e Gás & 0.3866 & -0.9527 & 0.4280 & 2.5978 & 120.50 & 137.50 \\
\hline 17485 & Energia Elétrica & 1.1230 & -0.7938 & 0.2075 & 0.4224 & 120.50 & 37.00 \\
\hline 922 & Finanças e Seguros & 0.1838 & -0.9907 & 0.7452 & 6.9540 & 119.75 & 182.00 \\
\hline 7811 & Construção & 0.2675 & -0.9871 & 0.6020 & 4.6512 & 119.75 & 169.50 \\
\hline 13439 & Veículos e peças & 0.5425 & -0.8299 & 0.0194 & 3.8302 & 119.00 & 87.50 \\
\hline 8133 & Comércio & 1.0237 & -0.8592 & 0.1691 & 1.0565 & 118.25 & 53.00 \\
\hline 2445 & Energia Elétrica & 0.6232 & -0.9324 & 0.6700 & 0.9691 & 118.00 & 102.50 \\
\hline 17671 & Telecomunicações & 0.4949 & -0.9629 & 0.4587 & 2.4852 & 117.75 & 133.00 \\
\hline 16632 & Outros & 0.6125 & -0.6496 & 0.1149 & 1.7284 & 117.50 & 65.00 \\
\hline 13366 & Siderurgia \& Metalurgia & 0.9162 & -0.5636 & 0.1310 & 0.8324 & 117.50 & 33.00 \\
\hline 14869 & Energia Elétrica & 0.5423 & -0.9205 & 0.3499 & 1.9217 & 117.25 & 109.00 \\
\hline 7544 & Têxtil & 0.8185 & -0.9316 & 0.8846 & 0.4392 & 117.25 & 84.00 \\
\hline 12319 & Alimentos e Bebidas & 0.2417 & -0.9822 & 0.5492 & 8.8314 & 117.00 & 169.50 \\
\hline 11932 & Veículos e peças & 0.8591 & -0.7779 & 0.0991 & 1.5330 & 116.75 & 53.00 \\
\hline 14133 & Outros & 0.1629 & -0.9856 & 2.4774 & 3.3167 & 115.25 & 179.00 \\
\hline 13765 & Alimentos e Bebidas & 0.4492 & -0.7322 & 1.0296 & 0.4546 & 115.25 & 89.00 \\
\hline 16101 & Construção & 0.1319 & -0.9925 & 4.4611 & 5.9221 & 113.75 & 193.50 \\
\hline 4359 & Química & 0.9181 & 0.0059 & 0.1604 & 0.5465 & 113.75 & 23.00 \\
\hline 4650 & Siderurgia \& Metalurgia & 0.7950 & -0.6579 & 0.1102 & 1.5014 & 113.25 & 47.50 \\
\hline 13994 & Química & 0.6992 & -0.7680 & 0.0159 & 3.0907 & 113.00 & 66.50 \\
\hline 18597 & Outros & 0.4183 & -0.8765 & 0.2327 & 4.0961 & 112.75 & 113.50 \\
\hline
\end{tabular}


Tabela 3 (continuação)

\begin{tabular}{|c|c|c|c|c|c|c|c|}
\hline $\begin{array}{c}\text { CÓDIGO } \\
\text { CVM }\end{array}$ & SETOR ECONÔMICO & $\begin{array}{c}\text { EM1 } \\
(-)\end{array}$ & $\begin{array}{c}\text { EM2 } \\
(-)\end{array}$ & $\begin{array}{c}\text { EM3 } \\
(+)\end{array}$ & $\begin{array}{c}\text { EM5 } \\
(+)\end{array}$ & EM6 & EM1_2 \\
\hline 13986 & Papel e Celulose & 1.5779 & -0.8994 & 0.1502 & 1.2995 & 112.25 & 47.00 \\
\hline 3395 & Têxtil & 0.5193 & -0.9574 & 0.4723 & 2.9418 & 111.50 & 127.00 \\
\hline 17710 & Telecomunicações & 0.8425 & -0.8538 & 0.5950 & 0.4717 & 111.50 & 64.00 \\
\hline 11258 & Outros & 1.0423 & 0.1964 & 0.0785 & 0.9142 & 111.00 & 15.00 \\
\hline 2038 & Têxtil & 0.6570 & -0.9815 & 0.5256 & 2.3520 & 110.50 & 123.00 \\
\hline 3980 & Siderurgia \& Metalurgia & 0.7762 & -0.6746 & 0.1083 & 1.7328 & 110.50 & 50.50 \\
\hline 4170 & Mineração & 0.8544 & -0.2592 & 0.1003 & 1.2614 & 110.00 & 30.50 \\
\hline 11592 & Química & 0.6572 & -0.8469 & 0.1662 & 2.4328 & 109.50 & 78.50 \\
\hline 14451 & Energia Elétrica & 0.6071 & -0.8039 & 0.3804 & 1.4366 & 108.75 & 80.00 \\
\hline 17329 & Energia Elétrica & 0.5977 & -0.7365 & 0.2851 & 1.5637 & 108.50 & 74.00 \\
\hline 14559 & Química & 0.7473 & -0.9894 & 0.5715 & 2.4261 & 108.25 & 122.00 \\
\hline 7617 & Outros & 0.3452 & -0.9877 & 0.7053 & 11.8534 & 107.25 & 163.50 \\
\hline 18139 & Energia Elétrica & 0.8021 & -0.7526 & 0.1813 & 1.5323 & 107.25 & 54.00 \\
\hline 19348 & Finanças e Seguros & 0.1730 & -0.9936 & 6.1162 & 11.9825 & 106.75 & 191.50 \\
\hline 8311 & Mineração & 0.9348 & -0.9465 & 0.1473 & 3.6502 & 106.25 & 80.50 \\
\hline 11312 & Telecomunicações & 0.5611 & -0.9056 & 0.6613 & 1.6304 & 105.00 & 102.50 \\
\hline 20087 & Veículos e peças & 0.9206 & -0.9095 & 0.1190 & 3.3061 & 104.50 & 68.00 \\
\hline 12262 & Telecomunicações & 0.7270 & -0.9940 & 0.4837 & 6.8470 & 104.25 & 135.50 \\
\hline 17442 & Telecomunicações & 0.7360 & -0.9959 & 0.4789 & 9.5362 & 103.75 & 138.00 \\
\hline 14109 & Veículos e peças & 0.8785 & -0.6307 & 0.0819 & 1.8987 & 103.25 & 38.00 \\
\hline 8648 & Siderurgia \& Metalurgia & 0.6241 & -0.9043 & 0.4273 & 2.1796 & 102.75 & 94.00 \\
\hline 3298 & Outros & 0.2063 & -0.9910 & 7.6008 & 10.3764 & 102.25 & 181.50 \\
\hline 16616 & Petróleo e Gás & 0.6771 & -0.8343 & 0.2038 & 2.7520 & 102.00 & 74.00 \\
\hline 2461 & Energia Elétrica & 0.8055 & -0.4984 & 0.1226 & 1.8073 & 102.00 & 40.00 \\
\hline 6173 & Siderurgia \& Metalurgia & 0.8688 & -0.8455 & 0.1192 & 2.9527 & 102.00 & 58.50 \\
\hline 3158 & Têxtil & 0.7600 & -0.9434 & 0.3675 & 2.5101 & 101.75 & 94.50 \\
\hline 15636 & Petróleo e Gás & 0.7024 & -0.7633 & 0.2008 & 2.3292 & 101.25 & 65.00 \\
\hline 16195 & Telecomunicações & 0.4547 & -0.9452 & 2.7366 & 1.7951 & 101.00 & 126.50 \\
\hline 16861 & Outros & 0.9479 & -0.6926 & 0.4694 & 0.5386 & 100.75 & 36.00 \\
\hline 11223 & Têxtil & 0.4827 & -0.8549 & 1.3851 & 1.3634 & 100.50 & 101.50 \\
\hline 14664 & Veículos e peças & 0.7171 & -0.6047 & 0.1481 & 2.3997 & 99.00 & 52.50 \\
\hline 9997 & Petróleo e Gás & 0.9379 & -0.5393 & 0.2557 & 1.2366 & 96.75 & 29.00 \\
\hline 14532 & Papel e Celulose & 0.4259 & -0.7052 & 0.4560 & 2.4215 & 96.50 & 90.00 \\
\hline 8427 & Outros & 0.8509 & -0.8731 & 0.8951 & 0.9453 & 96.50 & 68.00 \\
\hline 11975 & Construção & 1.0532 & -0.8722 & 0.1414 & 3.2701 & 95.75 & 53.00 \\
\hline 9040 & Minerais não Met. & 0.6703 & -0.4824 & 0.1759 & 2.3262 & 95.50 & 51.50 \\
\hline 4537 & Comércio & 0.8532 & -0.6217 & 0.1624 & 2.0162 & 95.00 & 40.50 \\
\hline 12580 & Alimentos e Bebidas & 0.6644 & -0.8441 & 1.1939 & 1.1275 & 94.75 & 77.00 \\
\hline 1694 & Veículos e peças & 0.8289 & -0.8300 & 1.0172 & 0.7733 & 94.50 & 59.50 \\
\hline 13471 & Veículos e peças & 0.7452 & -0.9144 & 1.3297 & 1.3107 & 94.25 & 87.00 \\
\hline 6378 & Siderurgia \& Metalurgia & 0.9922 & -0.8720 & 2.8201 & 0.2093 & 93.75 & 56.00 \\
\hline 1520 & Máquinas Indust. & 0.3410 & -0.9469 & 2.1341 & 4.4188 & 93.25 & 142.50 \\
\hline 14311 & Energia Elétrica & 1.1968 & -0.6260 & 0.3154 & 1.1098 & 89.75 & 20.50 \\
\hline 17647 & Telecomunicações & 1.0705 & -0.8586 & 0.6834 & 0.9696 & 89.50 & 48.00 \\
\hline 4146 & Têxtil & 1.0763 & -0.4581 & 0.3719 & 0.8462 & 89.25 & 18.50 \\
\hline 12793 & Papel e Celulose & 1.9805 & -0.5321 & 0.3170 & 0.9050 & 88.00 & 11.50 \\
\hline 4669 & Têxtil & 0.6178 & -0.7110 & 0.4998 & 2.0262 & 87.50 & 69.50 \\
\hline
\end{tabular}


Tabela 3 (continuação)

\begin{tabular}{|c|c|c|c|c|c|c|c|}
\hline $\begin{array}{c}\text { CÓDIGO } \\
\text { CVM }\end{array}$ & SETOR ECONÔMICO & $\begin{array}{c}\text { EM1 } \\
(-)\end{array}$ & $\begin{array}{c}\text { EM2 } \\
(-)\end{array}$ & $\begin{array}{c}\text { EM3 } \\
(+)\end{array}$ & $\begin{array}{c}\text { EM5 } \\
(+)\end{array}$ & EM6 & EM1_2 \\
\hline 12696 & Outros & 0.8684 & -0.8342 & 0.8311 & 1.2397 & 86.50 & 56.50 \\
\hline 10880 & Outros & 1.0949 & -0.4403 & 0.2164 & 1.5244 & 86.50 & 17.50 \\
\hline 18376 & Energia Elétrica & 1.4549 & 0.0209 & 0.2886 & 0.9006 & 86.50 & 4.50 \\
\hline 14460 & Construção & 0.5102 & -0.9015 & 9.7543 & 2.0344 & 85.25 & 107.50 \\
\hline 6505 & Comércio & 0.6949 & -0.8432 & 0.2731 & 6.5082 & 85.25 & 74.00 \\
\hline 11207 & Outros & 0.3924 & -0.9346 & 2.6123 & 4.4174 & 85.00 & 129.00 \\
\hline 17280 & Telecomunicações & 0.5192 & -0.7538 & 0.9284 & 2.0167 & 84.75 & 84.50 \\
\hline 1562 & Outros & 1.0228 & -0.2884 & 0.6007 & 0.7018 & 83.75 & 20.50 \\
\hline 17752 & Finanças e Seguros & 0.8850 & -0.9198 & 0.3458 & 4.6404 & 83.50 & 74.00 \\
\hline 6700 & Outros & 1.1601 & -0.5703 & 0.6241 & 0.6911 & 82.75 & 19.50 \\
\hline 13722 & Siderurgia \& Metalurgia & 0.7924 & -0.8704 & 0.8288 & 1.8884 & 82.25 & 71.00 \\
\hline 10960 & Eletroeletrônicos & 0.7353 & -0.7581 & 0.8794 & 1.5998 & 81.00 & 62.00 \\
\hline 9342 & Comércio & 0.8766 & -0.4337 & 0.0797 & 5.9894 & 81.00 & 30.50 \\
\hline 2810 & Outros & 0.9191 & -0.6815 & 0.5063 & 1.4300 & 81.00 & 37.50 \\
\hline 3115 & Finanças e Seguros & 1.9738 & -0.6760 & 0.4872 & 0.9181 & 80.75 & 18.00 \\
\hline 4758 & Construção & 1.1483 & -0.8639 & 3.2270 & 0.7026 & 80.50 & 45.50 \\
\hline 10227 & Alimentos e Bebidas & 1.0683 & -0.6941 & 0.3077 & 2.0022 & 79.75 & 31.00 \\
\hline 3140 & Finanças e Seguros & 0.5075 & -0.8761 & 1.6927 & 3.3023 & 79.50 & 104.00 \\
\hline 8397 & Siderurgia \& Metalurgia & 1.4306 & -0.4297 & 0.1840 & 1.7890 & 79.25 & 9.00 \\
\hline 5983 & Têxtil & 0.6420 & -0.7670 & 1.4872 & 1.5698 & 79.00 & 71.00 \\
\hline 5827 & Têxtil & 1.4239 & -0.7378 & 2.2822 & 0.4996 & 77.25 & 26.50 \\
\hline 3336 & Alimentos e Bebidas & 0.8663 & -0.9525 & 4.4245 & 2.1090 & 76.25 & 88.50 \\
\hline 6211 & Veículos e peças & 1.3466 & 0.4054 & 0.0869 & 3.2430 & 75.75 & 6.00 \\
\hline 6076 & Finanças e Seguros & 1.2067 & -0.6995 & 2.0735 & 0.6711 & 74.25 & 26.00 \\
\hline 15261 & Outros & 1.0247 & -0.1873 & 0.9312 & 0.7924 & 73.75 & 18.00 \\
\hline 8486 & Têxtil & 1.1047 & -0.2551 & 0.4907 & 1.2022 & 73.75 & 13.00 \\
\hline 3603 & Alimentos e Bebidas & 1.0622 & -0.4386 & 0.3631 & 1.7188 & 73.25 & 19.50 \\
\hline 5207 & Têxtil & 2.0722 & -0.8126 & 0.9614 & 1.1463 & 71.00 & 29.50 \\
\hline 3204 & Energia Elétrica & 1.0408 & -0.7874 & 0.3228 & 4.0791 & 69.75 & 42.00 \\
\hline 3077 & Têxtil & 1.1052 & -0.4976 & 0.4456 & 1.6650 & 69.50 & 18.00 \\
\hline 17604 & Telecomunicações & 0.6876 & -0.6523 & 0.9638 & 2.0584 & 69.00 & 57.00 \\
\hline 10596 & Construção & 1.5062 & -0.6900 & 3.0161 & 0.7810 & 66.75 & 20.50 \\
\hline 4693 & Alimentos e Bebidas & 0.7282 & -0.8862 & 4.4240 & 4.1234 & 59.75 & 82.00 \\
\hline 16993 & Energia Elétrica & 1.3825 & -0.3915 & 2.6820 & 0.9314 & 57.00 & 9.50 \\
\hline 2437 & Energia Elétrica & 1.0658 & -0.4047 & 0.2680 & 7.7271 & 55.00 & 17.50 \\
\hline 12823 & Siderurgia \& Metalurgia & 1.0259 & -0.7740 & 6.2475 & 1.8484 & 53.75 & 41.00 \\
\hline 8451 & Veículos e peças & 1.4280 & -0.5136 & 0.7514 & 6.5282 & 33.50 & 13.50 \\
\hline
\end{tabular}

É possível verificar pela tabela acima certa similaridade entre as variáveis EM1 e EM2 quanto à magnitude do gerenciamento de resultados, ou seja, a indicação de um menor gerenciamento em uma é acompanhada pela mesma indicação pela outra. Por exemplo, a métrica EM1 da empresa 3174 demonstra uma tendência de suavização dos lucros reportados, similarmente, a métrica EM2 para a mesma empresa indica uma alta correlação negativa entre 
os accruals e o fluxo de caixa operacional, reforçando a tendência de suavização de resultados. Em mais um exemplo, as métricas EM1 e EM2 para a empresa 3891 apresentam a mesma tendência de gerenciamento de resultados, acompanhada pela métrica EM5 na qual a volatilidade dos lucros antes dos accruals discricionários é bem maior que a volatilidade do lucro líquido, demonstrando, assim, tendência à suavização de resultados.

Ressalta-se, porém, que referida tendência das variáveis EM1 e EM2 nem sempre é acompanhada pelas variáveis EM3 e EM5 para todas as empresas, o que pode ser verificado, por exemplo, na empresa 16101, na qual as variáveis EM3 e EM5 demonstram tendência à suavização de resultados não nitidamente acompanhada pela variável EM1. Dessa forma, de maneira a simplificar a análise, a tabela a seguir apresenta os resultados das métricas de gerenciamento por setor econômico.

Tabela 4 - Métricas de gerenciamento de resultados por setor econômico (classificadas por EM6)

\begin{abstract}
As variáveis foram calculadas para 948 observações para os anos de 2002 a 2007. Foram excluídos os setores "Agro e Pesca" e "Outros", o primeiro por ser representado apenas por uma empresa; e o segundo por abranger atividades diversas. EM1 é calculada pelo desvio-padrão do lucro operacional pelo desvio padrão do fluxo de caixa operacional (ambos divididos pelo total de ativos). O fluxo de caixa operacional é calculado indiretamente pela diferença entre o lucro operacional e os accruals totais. EM2 representa a correlação das variações dos accruals totais com as variações do fluxo de caixa operacional (ambos divididos pelos ativos totais). EM3 é a taxa média dos valores absolutos dos accruals e o valor absoluto do fluxo de caixa operacional. EM5 é calculada pelo desvio padrão do lucro não discricionário pelo desvio padrão do lucro líquido (ambos divididos pelos ativos totais). O lucro não discricionário é a somatória do fluxo de caixa operacional e os accruals não discricionários, sendo estes calculados pelo modelo modificado de Jones (1991). EM6 (aggregate earnings management score) representa a média das quatro métricas (EM1, EM2, EM3 e EM5) e EM1_2 representa a média das duas primeiras métricas. EM4 não foi calculada pois seriam necessários, no mínimo, cinco observações de 'pequenos lucros' para cada empresa na amostra (LEUZ et al, 2002, p. 9). Os sinais nas colunas indicam se altos valores para as respectivas métricas implicam em maiores (+) ou menores (-) gerenciamento de resultados.
\end{abstract}

\begin{tabular}{|l|c|c|c|c|c|c|}
\multicolumn{1}{|c|}{ SETOR ECONÔMICO } & $\begin{array}{c}\text { EM1 } \\
(-)\end{array}$ & $\begin{array}{c}\text { EM2 } \\
(-)\end{array}$ & $\begin{array}{c}\text { EM3 } \\
(+)\end{array}$ & $\begin{array}{c}\text { EM5 } \\
(+)\end{array}$ & EM6 & EM1_2 \\
\hline VEÍCULOS E PEÇAS & 0.04446 & -0.99986 & 2.88853 & 1.32860 & 14.75 & 17 \\
\hline FINANÇAS E SEGUROS & 0.36283 & -0.95569 & 0.34757 & 2.56214 & 13.75 & 14.5 \\
\hline TELECOMUNICAÇÕES & 0.53496 & -0.97841 & 1.05106 & 1.08024 & 12.25 & 15 \\
\hline MINERAIS NÃO MET. & 0.67223 & -0.98071 & 0.69842 & 1.34027 & 12.25 & 13.5 \\
\hline CONSTRUÇÃO & 0.68136 & -0.92429 & 1.08719 & 1.56481 & 11 & 9 \\
\hline PETRÓLEO E GÁS & 0.75257 & -0.93109 & 0.23839 & 3.29292 & 9.25 & 7.5 \\
\hline ELETRÔNICOS & 0.81709 & -0.83809 & 2.01745 & 2.47440 & 9.25 & 3 \\
\hline ENERGIA ELÉTRICA & 0.68528 & -0.92576 & 0.26378 & 1.34733 & 8.75 & 9 \\
\hline QUÍMICA & 0.66814 & -0.86182 & 0.18332 & 2.43226 & 8.75 & 8.5 \\
\hline ALIMENTOS E BIBIDAS & 0.55020 & -0.93418 & 0.27222 & 0.43324 & 8.5 & 12.5 \\
\hline SIDERURGIA E METALURGIA & 0.61661 & -0.94186 & 0.09089 & 0.78103 & 7.75 & 12.5 \\
\hline TRANSPORTE E SERVIÇOS & 0.74835 & -0.91833 & 0.37956 & 1.17190 & 7.75 & 6.5 \\
\hline COMÉRCIO & 0.69496 & -0.89973 & 0.00559 & 1.82680 & 6.75 & 7 \\
\hline MÁQUINAS INDUST. & 1.08651 & -0.97496 & 0.25584 & 0.93677 & 6.25 & 7.5 \\
\hline PAPEL E CELULOSE & 0.71817 & -0.81688 & 0.29388 & 1.09296 & 6 & 4.5 \\
\hline MINERAÇÃO & 0.80586 & -0.55133 & 0.03225 & 2.40933 & 5 & 2.5 \\
\hline TÊXTIL & 0.93348 & -0.84437 & 0.58671 & 0.69035 & 5 & 3 \\
\hline
\end{tabular}


A tabela 4 demonstra que quando agrupadas por setores econômicos as métricas de gerenciamento de resultados apresentam melhor relacionamento. Exemplificando, a métrica EM1 indica que os setores de "Veículos e Peças" e "Finanças e Seguros" apresentam uma maior tendência no gerenciamento de resultados, acompanhada pela mesma indicação nas métricas EM2 e EM3 no primeiro caso, e por EM2 e EM5 no segundo. Importante destacar que para os setores que demonstraram menor gerenciamento de resultados, isso é indicado simultaneamente por todas as métricas.

Com o propósito de identificar similaridades entre as empresas com relação aos mecanismos de governança corporativa, realizou-se uma análise de clusters (agrupamentos). Segundo Hair et al (2005, p. 384), a análise de agrupamentos classifica objetos de modo que cada objeto é muito semelhante aos outros no agrupamento, sendo que os agrupamentos resultantes de objetos devem exibir elevada homogeneidade interna e elevada heterogeneidade externa. As variáveis foram padronizadas para que pudessem contribuir de modo igual para a análise e fez-se uso do agrupamento não-hierárquico " $k$-means" em três clusters.

Tabela 5 - Resumo da análise de clusters

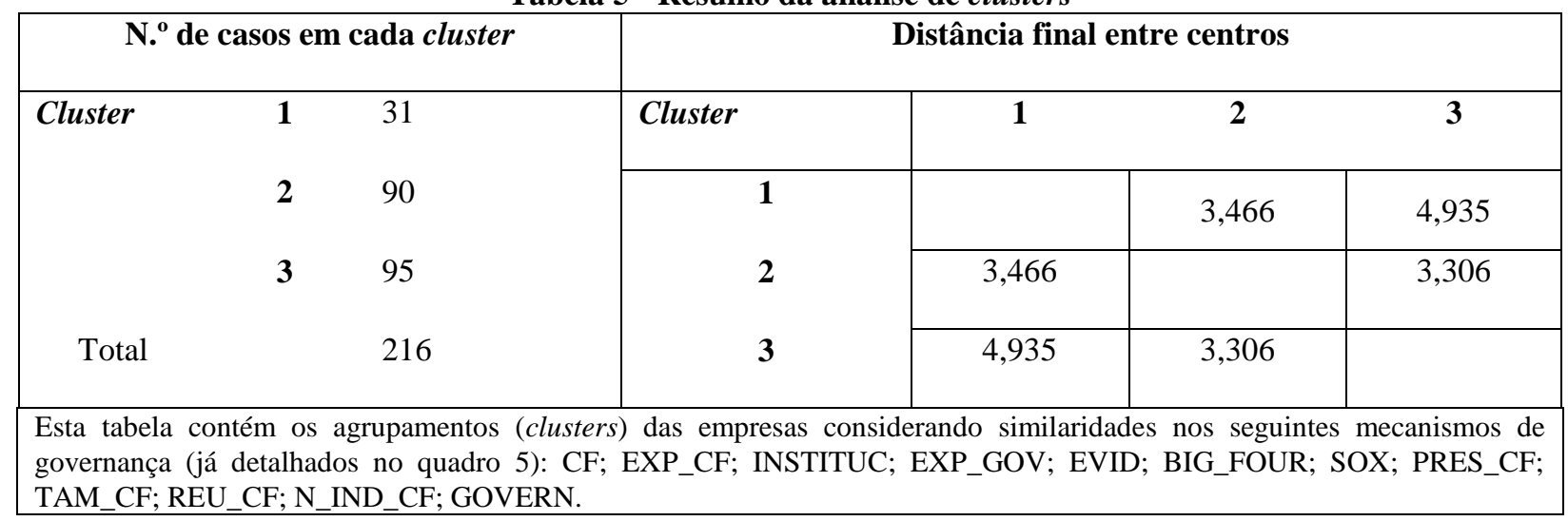

Verifica-se que o primeiro cluster é formado por 31 observações, e os cluster 2 e 3 apresentam número de observações muito próximo, 90 e 95 observações respectivamente. De fato, pelas distâncias centrais dos clusters, identifica-se que o cluster 2 está mais próximo ao cluster 3 do que ao cluster 1, o que pode indicar certa similaridade de observações. A composição média das características dos clusters é indicada na tabela 6 abaixo: 
Tabela 6 - Centros finais dos clusters e ANOVA

\begin{tabular}{|l|c|c|c|c|c|c|}
\hline \multirow{2}{*}{ VARIÁ_VEIS } & \multicolumn{3}{|c}{ CLUSTERS } & \multicolumn{3}{c|}{ ANOVA } \\
\cline { 2 - 7 } & $\mathbf{1}$ & $\mathbf{2}$ & $\mathbf{3}$ & $\begin{array}{c}\text { CLUSTER } \\
\text { MEAN } \\
\text { SQUARE }\end{array}$ & $\begin{array}{c}\text { ERROR } \\
\text { MEAN } \\
\text { SQUARE }\end{array}$ & SIG \\
\hline CF &, 66447 &, 72167 &,- 90051 & 68,799 &, 363 &, 000 \\
\hline EXP_CF &, 86061 &, 43123 &,- 68936 & 42,421 &, 611 &, 000 \\
\hline INSTITUC &, 04041 &, 20251 &,- 20504 & 3,868 &, 973 &, 020 \\
\hline EXP_GOV & 1,88793 &,- 28006 &,- 35074 & 64,619 &, 403 &, 000 \\
\hline EVID &, 86401 &, 29267 &,- 55920 & 30,279 &, 725 &, 000 \\
\hline BIG_FOUR &, 73369 &, 42470 &,- 64176 & 36,023 &, 671 &, 000 \\
\hline SOX &, 67312 &, 05141 &,- 26835 & 10,562 &, 910 &, 000 \\
\hline PRES_CF &,- 08763 &, 45251 &,- 40010 & 16,937 &, 850 &, 000 \\
\hline TAM_CF &, 63080 &, 70749 &,- 87610 & 65,150 &, 398 &, 000 \\
\hline REU_CF &, 25326 &, 16832 &,- 24210 & 5,053 &, 962 &, 006 \\
\hline N_IND_CF &, 51405 &, 54015 &,- 67946 & 39,155 &, 642 &, 000 \\
\hline GOVERN & 1,90371 &,- 35713 &,- 28287 & 65,714 &, 392 &, 000 \\
\hline $\begin{array}{l}\text { Esta tabela contém os valores médios das variáveis em cada um dos agrupamentos (clusters). As colunas de } \\
\text { 'ANOVA' demonstram a participação de cada variável na constituição dos agrupamentos. As variáveis } \\
\text { encontram-se detalhadas no quadro 5. }\end{array}$ \\
\hline
\end{tabular}

As variáveis de governança corporativa no cluster 1 são compostas quase que exclusivamente por números positivos, indicando a existência desses componentes de governança em tal amostra. Por outro lado, os clusters 2 e 3 alternam a indicação sobre a existência dos instrumentos de governança, tornando difícil classificar qual dos dois grupos seria mais robusto com a relação à existência de referidos instrumentos. A composição dos clusters por empresas está contida nas tabelas 7,8 e 9 . 
Tabela 7 - Empresas do cluster 1 (classificadas por EM6)

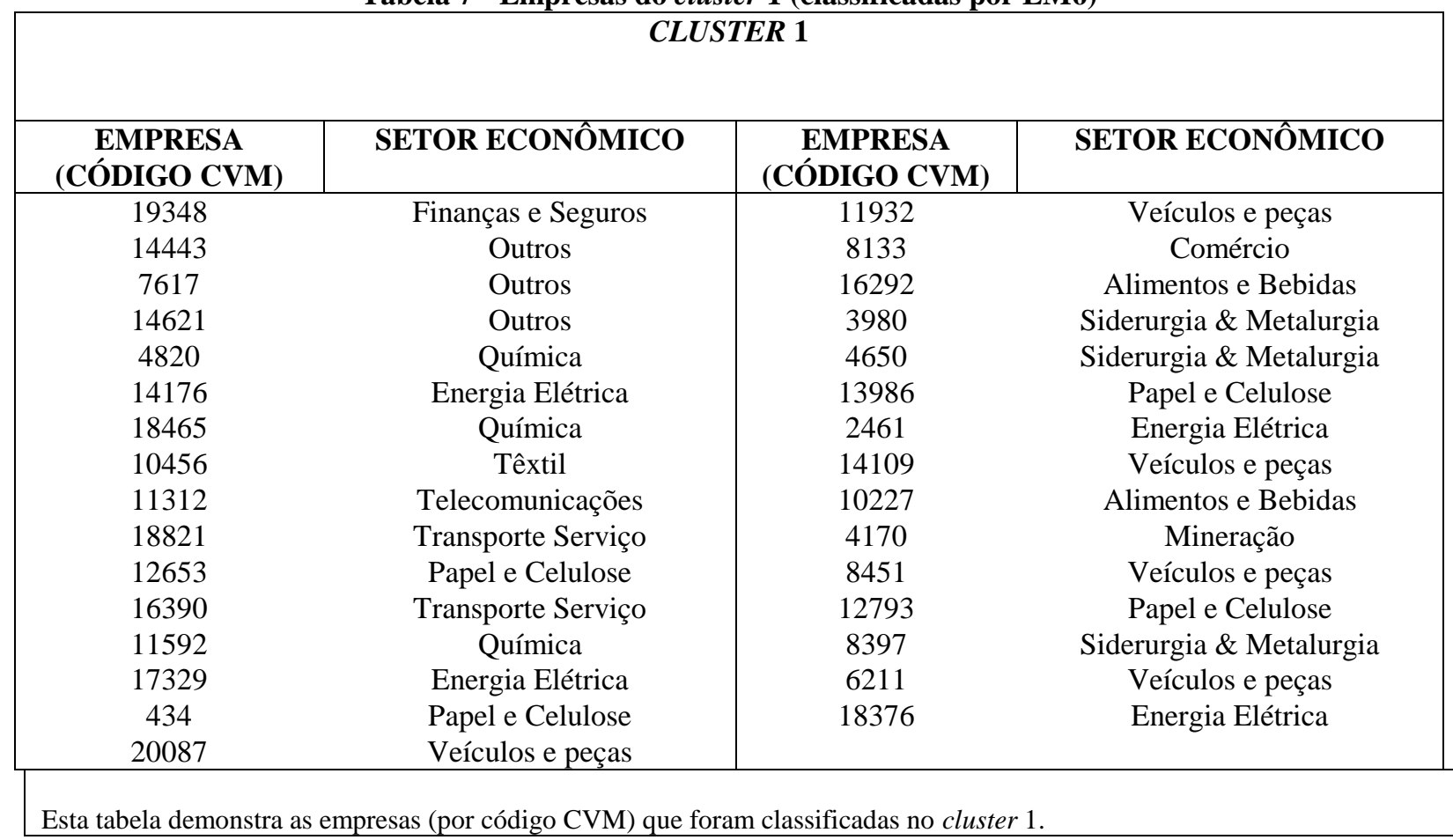


Tabela 8 - Empresas do cluster 2 (classificadas por EM6)

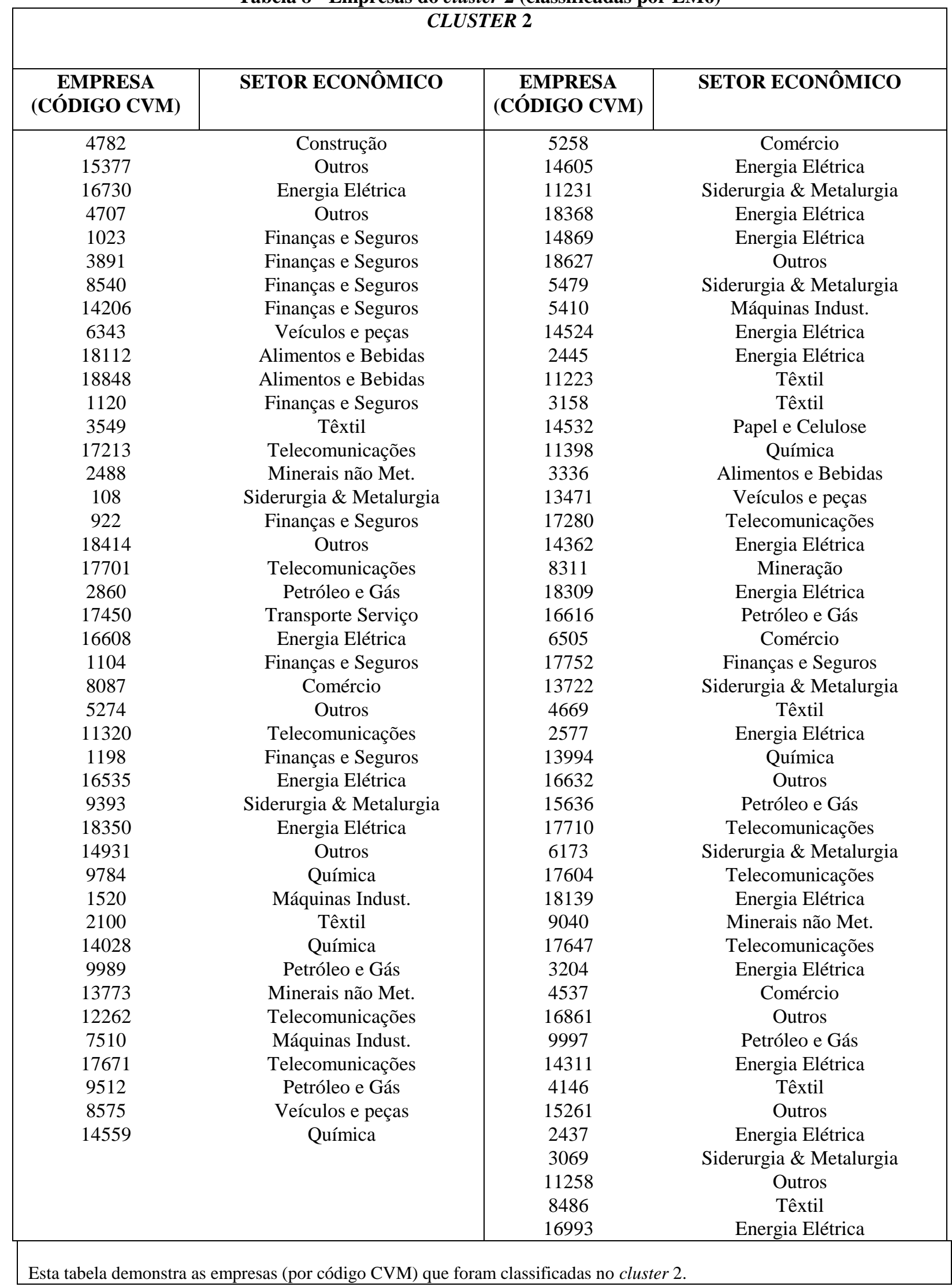


Tabela 9 - Empresas do cluster 3 (classificadas por EM6)

\begin{tabular}{|c|c|c|c|}
\hline \multicolumn{4}{|c|}{ CLUSTER 3} \\
\hline $\begin{array}{c}\text { EMPRESA } \\
\text { (CÓDIGO CVM) }\end{array}$ & SETOR ECONÔMICO & $\begin{array}{c}\text { EMPRESA } \\
\text { (CÓDIGO } \\
\text { CVM) }\end{array}$ & SETOR ECONÔMICO \\
\hline 4448 & Veículos e peças & 18597 & Outros \\
\hline 6041 & Outros & 4057 & Outros \\
\hline 3174 & Transporte Serviço & 14460 & Construção \\
\hline 16497 & Têxtil & 3140 & Finanças e Seguros \\
\hline 1155 & Finanças e Seguros & 5312 & Siderurgia \& Metalurgia \\
\hline 13030 & Construção & 1309 & Finanças e Seguros \\
\hline 5150 & Veículos e peças & 2429 & Papel e Celulose \\
\hline 16101 & Construção & 574 & Outros \\
\hline 4774 & Construção & 8648 & Siderurgia \& Metalurgia \\
\hline 13285 & Alimentos e Bebidas & 15865 & Outros \\
\hline 4723 & Construção & 13765 & Alimentos e Bebidas \\
\hline 9415 & Outros & 13439 & Veículos e peças \\
\hline 9083 & Máquinas Indust. & 13412 & Outros \\
\hline 3298 & Outros & 7544 & Têxtil \\
\hline 14133 & Outros & 10588 & Eletroeletrônicos \\
\hline 2909 & Alimentos e Bebidas & 4693 & Alimentos e Bebidas \\
\hline 8117 & Comércio & 5991 & Têxtil \\
\hline 14826 & Comércio & 14451 & Energia Elétrica \\
\hline 12319 & Alimentos e Bebidas & 11762 & Têxtil \\
\hline 7811 & Construção & 18279 & Agro e Pesca \\
\hline 5770 & Outros & 12580 & Alimentos e Bebidas \\
\hline 8818 & Comércio & 10472 & Outros \\
\hline 8893 & Outros & 5983 & Têxtil \\
\hline 15423 & Telecomunicações & 8427 & Outros \\
\hline 15881 & Veículos e peças & 10960 & Eletroeletrônicos \\
\hline 13854 & Outros & 1694 & Veículos e peças \\
\hline 14761 & Têxtil & 12696 & Outros \\
\hline 7978 & Outros & 6378 & Siderurgia \& Metalurgia \\
\hline 8192 & Outros & 13447 & Outros \\
\hline 5762 & Minerais não Met. & 11975 & Construção \\
\hline 13781 & Outros & 14664 & Veículos e peças \\
\hline 16527 & Energia Elétrica & 4758 & Construção \\
\hline 11070 & Petróleo e Gás & 12823 & Siderurgia \& Metalurgia \\
\hline 6017 & Siderurgia \& Metalurgia & 2810 & Outros \\
\hline 17442 & Telecomunicações & 17485 & Energia Elétrica \\
\hline 7447 & Siderurgia \& Metalurgia & 13366 & Siderurgia \& Metalurgia \\
\hline 2062 & Alimentos e Bebidas & 9342 & Comércio \\
\hline 12530 & Eletroeletrônicos & 5207 & Têxtil \\
\hline 11207 & Outros & 5827 & Têxtil \\
\hline 1970 & Eletroeletrônicos & 6076 & Finanças e Seguros \\
\hline 3395 & Têxtil & 4359 & Química \\
\hline 16195 & Telecomunicações & 1562 & Outros \\
\hline 4030 & Siderurgia \& Metalurgia & 10596 & Construção \\
\hline 2038 & Têxtil & 3603 & Alimentos e Bebidas \\
\hline 15695 & Outros & 6700 & Outros \\
\hline 8605 & Siderurgia \& Metalurgia & 3115 & Finanças e Seguros \\
\hline 6513 & Construção & 3077 & Têxtil \\
\hline & & 10880 & Outros \\
\hline
\end{tabular}


Para verificar se existem diferenças relativamente ao nível de gerenciamento de resultados nas três amostras, realizou-se o teste de Kruska-Wallis ${ }^{12}$. Ressalta-se que as métricas de gerenciamento de resultados utilizadas neste teste foram as EM1 e EM2, por representarem o gerenciamento de resultados com relação à variabilidade e suavização dos lucros reportados considerando em menor escala o julgamento dos gestores no exercício da discricionaridade, conforme sugerem as métricas EM3 e EM5, em conseqüência, a métrica de classificação média utilizada foi a EM1_2.

Tabela 10 - Kruskal Wallis Test

\begin{tabular}{|c|c|c|c|c|c|}
\hline VARIÁVEIS & $\begin{array}{c}\text { CLUSTER } \\
\text { NUMBER OF } \\
\text { CASE }\end{array}$ & $\mathbf{N}$ & MEAN RANK & CHI-SQUARE & ASYMP. SIG \\
\hline \multirow{4}{*}{ EM1_2 } & 1 & 31 & 72,55 & \multirow{4}{*}{12,112} & \multirow{4}{*}{,002 } \\
\hline & 2 & 90 & 116,26 & & \\
\hline & 3 & 95 & 112,88 & & \\
\hline & Total & 216 & & & \\
\hline \multicolumn{6}{|c|}{$\begin{array}{l}\text { a Kruskal Wallis Test } \\
\text { b Grouping Variable: Cluster Number of Case }\end{array}$} \\
\hline
\end{tabular}

A estatística de teste (chi-square) e a probabilidade de significância calculadas trazem a conclusão que existe pelo menos um grupo cujo nível de gerenciamento de resultados difere dos demais. A mean rank sugere que o cluster 1, que é o que apresenta os mecanismos de governança quase que na totalidade, teria o menor nível de gerenciamento de resultados.

De posse dessas conclusões, procurou-se testar o relacionamento dos instrumentos de governança corporativa com as métricas de gerenciamento de resultados por meio de regressões simples. Foram calculadas várias regressões (1 a 8) com composições diferenciadas de variáveis apresentadas na tabela 11.

${ }^{12} \mathrm{O}$ teste de Kruskal Wallis é considerado uma alternativa não-paramétrica à ANOVA one-way. É utilizado para testar se duas ou mais amostras provêm de uma mesma população ou se populações diferentes (Maroco, 2003, p. 175). 
Tabela 11 - Regressões entre métricas de gerenciamento de resultados e possíveis mecanismos de governança corporativa

\begin{tabular}{|c|c|c|c|c|c|c|c|c|}
\hline \multirow[b]{2}{*}{ VARIÁVEIS } & \multicolumn{6}{|c|}{ EM1 } & \multicolumn{2}{|c|}{ EM2 } \\
\hline & 1 & 2 & 3 & 4 & 5 & 6 & 7 & 8 \\
\hline INTERCEPTO & $\begin{array}{c}0,6507 * * * \\
(3,73)\end{array}$ & $\begin{array}{c}0,8251^{*} \\
(5,02)\end{array}$ & $\begin{array}{c}0,8402 * * * \\
(5,17)\end{array}$ & & & $\begin{array}{c}0,8504 * * * \\
(5,23)\end{array}$ & $\begin{array}{c}-0,7668 * * * \\
(-7,89)\end{array}$ & $\begin{array}{c}-0,7411 * * * \\
(-7,81)\end{array}$ \\
\hline BIG_FOUR & $\begin{array}{c}-0,1299 \\
(-1,30)\end{array}$ & & & & & & & \\
\hline $\mathbf{C F}$ & $\begin{array}{c}0,2966 \\
(1,61)\end{array}$ & $\begin{array}{c}0,2661 * * \\
(2,85)\end{array}$ & $\begin{array}{c}0,2493^{*} \\
(2,75)\end{array}$ & $\begin{array}{c}0,2536^{*} \\
(2,77)\end{array}$ & $\begin{array}{c}0,2362^{*} \\
(2,60)\end{array}$ & $\begin{array}{c}0,2566^{* * *} \\
(2,85)\end{array}$ & $\begin{array}{c}0,0751 \\
(1,45)\end{array}$ & \\
\hline PRES_CF & $\begin{array}{c}-0,0833 \\
(-0,69)\end{array}$ & $\begin{array}{c}-0,0944 \\
(-0,79)\end{array}$ & & & & & & \\
\hline CAUD & $\begin{array}{c}-0,4405^{*} \\
(-2,71)\end{array}$ & & & & & & & \\
\hline GOVERN & $\begin{array}{c}0,0279 \\
(0,43)\end{array}$ & $\begin{array}{c}0,0003 \\
(0,01)\end{array}$ & $\begin{array}{c}0,0051 \\
(0,08)\end{array}$ & $\begin{array}{c}0,0074 \\
(0,12)\end{array}$ & $\begin{array}{c}-0,0051 \\
(-0,08)\end{array}$ & $\begin{array}{c}, 01957 * * \\
(2,87)\end{array}$ & & $\begin{array}{c}0,0663 \\
(2,08)\end{array}$ \\
\hline TAM_CF & $\begin{array}{c}-0,0037 \\
(-0,17)\end{array}$ & & & & & & & \\
\hline REU_CF & $\begin{array}{c}-0,2575 \\
(-1,46)\end{array}$ & & & & & & & \\
\hline P_IND_CF & $\begin{array}{c}0,0060 \\
(0,05)\end{array}$ & & & & & & & \\
\hline EXP_CF & $-0,2433$ & $\begin{array}{c}0,2504 \\
(0,43)\end{array}$ & & & & & & \\
\hline P_EXP_CF & $(-2,01)$ & & & & & & & \\
\hline INSTITUC & $\begin{array}{c}0,0018 \\
(0,64)\end{array}$ & $\begin{array}{c}0,0019 \\
(0,67)\end{array}$ & $\begin{array}{c}0,0018 \\
(0,64)\end{array}$ & $\begin{array}{c}0,0019 \\
(0,70)\end{array}$ & $\begin{array}{c}0,0021 \\
(0,74)\end{array}$ & & $\begin{array}{c}0,0037 \\
(2,29)\end{array}$ & $\begin{array}{c}0,0033 \\
(2,04)\end{array}$ \\
\hline LN_AT & $\begin{array}{c}-0,0184 \\
(-1,23) \\
\end{array}$ & $\begin{array}{c}-0,0274 \\
(-1,86)\end{array}$ & $\begin{array}{c}-0,0280 \\
(-1,91)\end{array}$ & $\begin{array}{l}-0,0217 \\
(-1,62) \\
\end{array}$ & $\begin{array}{c}-0,0232 \\
(-1,71)\end{array}$ & $\begin{array}{c}-0,0279 \\
(-2,06) \\
\end{array}$ & $\begin{array}{c}-0,0126 \\
(-1,62) \\
\end{array}$ & $\begin{array}{c}-0,0133 \\
(-1,70)\end{array}$ \\
\hline DIV_AT & $\begin{array}{c}-0,0241 \\
(-2,31)\end{array}$ & $\begin{array}{c}-0,0220 \\
(-2,09)\end{array}$ & $\begin{array}{c}-0,0219 \\
(-2,08)\end{array}$ & & $\begin{array}{c}-0,0215 \\
(-2,06)\end{array}$ & & $\begin{array}{c}-0,0058 \\
(-0,97)\end{array}$ & \\
\hline BCGI & & & & & $\begin{array}{l}0,2515 \\
(1,03)\end{array}$ & & $\begin{array}{l}0,0987 \\
(0,70)\end{array}$ & \\
\hline EVID & $\begin{array}{c}0,4149 \\
(1,95)\end{array}$ & $\begin{array}{c}0,1042 \\
(0,75)\end{array}$ & $\begin{array}{c}0,0961 \\
(0,70)\end{array}$ & & & & & \\
\hline CF_EXP & & $\begin{array}{c}-0,6076 \\
(-0,86)\end{array}$ & $\begin{array}{c}-0,3135^{*} \\
(-2,71)\end{array}$ & $\begin{array}{c}-0,3059^{*} \\
(-2,64)\end{array}$ & $\begin{array}{c}0,1066 \\
(0,41)\end{array}$ & $\begin{array}{c}-0,1042^{*} \\
(-1,67)\end{array}$ & $\begin{array}{c}0,4485^{*} \\
(3,01)\end{array}$ & \\
\hline EXP_GOV & $\begin{array}{c}0,3872^{*} \\
(2,62)\end{array}$ & $\begin{array}{c}0,4143^{* *} \\
(2,83)\end{array}$ & $\begin{array}{c}0,8402 * * \\
(2,90)\end{array}$ & $\begin{array}{c}0,4298 * * \\
(2,95)\end{array}$ & $\begin{array}{c}0,4484 * * \\
(3,10)\end{array}$ & & $\begin{array}{c}0,1369 \\
(1,65)\end{array}$ & \\
\hline $\mathrm{R}^{2}$ AJUST. & $9,5 \%$ & $7 \%$ & $8 \%$ & $7 \%$ & $11 \%$ & $6,5 \%$ & $13,5 \%$ & $4 \%$ \\
\hline PROB. (F) & 0,001 & 0,005 & 0,002 & 0,003 & 0,001 & 0,005 & 0,000 & 0,009 \\
\hline $\mathbf{N}^{\circ}$ EMPRESAS & 216 & 216 & 216 & 216 & 216 & 216 & 216 & 216 \\
\hline
\end{tabular}

De modo geral, poucas variáveis apresentaram relacionamento com as métricas de gerenciamento de resultados, exceção feita as variáveis existência de conselho fiscal (CF), existência de índice de governança da BOVESPA (GOVERN), existência de conselho fiscal 
com especialista em ciências contábeis (CF_EXP) e existência de especialista em ciências contábeis com existência de índice de governança BOVESPA (EXP_GOV).

Com relação ao conselho fiscal e a métrica de gerenciamento de resultados EM1, verificou-se que em cinco regressões de seis ele apresentou relacionamento positivo com gerenciamento de resultado, indicando que sua existência diminuiria as práticas de suavização de resultados, com níveis de significância de 5\% e 10\%. Outra análise interessante está relacionada com a formação dos conselheiros fiscais, variável CF_EXP, indicando que quando existe conselho fiscal com membros formados em ciências contábeis o nível de gerenciamento de resultados seria maior.

Contudo, analisando-se a variável EXP_GOV, o resultado encontrado é bastante surpreendente, ou seja, se além de existir conselho fiscal a empresa também tiver aderido aos níveis de governança da BOVESPA, a existência de conselheiro com formação em ciências contábeis mostra-se significante em todos os casos e está relacionada positivamente com menores níveis de gerenciamento de resultados.

Por sua vez, a variável dependente EM2, de forma geral, não demonstrou estar relacionada aos demais determinantes, com exceção à variável que indica a existência de conselho fiscal com especialista em ciências contábeis que em um nível de significância de $10 \%$ sugere menores níveis de gerenciamento de resultados.

Nesse momento torna-se importante ressaltar que outros estudos internacionais já foram realizados relacionando os níveis de gerenciamento de resultados e mecanismos de governança corporativa. Contudo, a diferença encontrada entre tais estudos e esta tese referese ao fato de que os instrumentos de governança são representados por características do conselho de administração e do comitê de auditoria, como encontrado, por exemplo, nos trabalhos de Chtourou et al (2001), Xie et al (2001) e Bradbury et al (2004). Em tais estudos, os resultados estatísticos encontrados sugerem que conselhos de administração e comitês de auditorias com membros especialistas em finanças e com alto grau de independência reduzem os níveis de gerenciamento de resultados. 
Com o propósito de analisar se os resultados encontrados também se aplicam ao Brasil, foram realizados testes similares aos estudos em questão, apenas substituindo as variáveis de comitê de auditoria por variáveis de conselho fiscal tendo como justificativas dois principais motivos já discutidos anteriormente neste trabalho: a figura do conselho fiscal no Brasil é obrigatória por lei, sendo o comitê de auditoria obrigatório apenas para as instituições financeiras (depois de atendidos alguns requisitos); e a previsão da constituição do comitê de auditoria é recente se comparada ao conselho fiscal (o primeiro surge nos anos 2000 e o segundo nos anos de 1970). Outra diferença destes trabalhos internacionais é a utilização do modelo modificado de Jones (1991) como métrica de gerenciamento de resultados (uso dos accruals discricionários), sendo que os valores encontrados para esta nova análise encontram-se na próxima seção.

\subsection{Análise estatística dos resultados - modelo modificado de Jones (1999)}

Nesta seção, foi utilizado o modelo modificado de Jones (1991) para o cálculo dos accruals discricionários conforme demonstrado no capítulo 4 desta tese. Utilizou-se o período de 2004 a 2007 para 216 empresas. Como ressaltado anteriormente, o número de empresas corresponde às que apresentavam dados para todos os anos, consoante necessidade do referido modelo na utilização de painel balanceado. Tendo como parâmetro os primeiros estudos sobre o tema (HEALY (1985), DEANGELO (1986), JONES (1991) e BARTOV et al (2000)) assumiu-se para os accruals discricionários valores absolutos e realizados três métodos de regressão: mínimos quadrados ordinários; efeito aleatório; e efeito fixo. Os valores calculados para cada empresa nos períodos correspondentes são apresentados na tabela a seguir: 
Tabela 12 - Regressões entre métrica de gerenciamento de resultados e possíveis mecanismos de governança corporativa

\begin{tabular}{|c|c|c|c|}
\hline \multirow[b]{2}{*}{ VARIÁVEIS } & \multicolumn{3}{|c|}{ AD } \\
\hline & MQO & $\mathbf{E F}$ & EA \\
\hline INTERCEPTO & $\begin{array}{c}0,7797 * * * \\
(3,62)\end{array}$ & $\begin{array}{l}-1,1758 \\
(-0,929)\end{array}$ & $\begin{array}{c}0,7797 * * * \\
(3,62)\end{array}$ \\
\hline CEO & $\begin{array}{l}-0,0392 \\
(-1,845)\end{array}$ & $\begin{array}{l}-0,0035 \\
(-0,195)\end{array}$ & $\begin{array}{l}-0,0392 \\
(-1,845)\end{array}$ \\
\hline TAM_AD & $\begin{array}{c}0,0132 \\
(1,83) \\
\end{array}$ & $\begin{array}{c}0,0003 \\
(0,064)\end{array}$ & $\begin{array}{c}0,0132 \\
(1,83)\end{array}$ \\
\hline P_IND_AD & $\begin{array}{l}-0,0080 \\
(-1,268) \\
\end{array}$ & $\begin{array}{l}0,0023 \\
(0,322) \\
\end{array}$ & $\begin{array}{l}-0,0080 \\
(-1,268)\end{array}$ \\
\hline P_IND_CF & $\begin{array}{l}0,0553 \\
(2,525)\end{array}$ & $\begin{array}{l}0,0317 \\
(0,610)\end{array}$ & $\begin{array}{l}0,0553 \\
(2,525)\end{array}$ \\
\hline ACION_MAJOR & $\begin{array}{l}-0,0767 \\
(-1,720)\end{array}$ & $\begin{array}{l}0,0149 \\
(0,547)\end{array}$ & $\begin{array}{l}-0,0767 \\
(-1,720)\end{array}$ \\
\hline DIR_MAJOR & $\begin{array}{l}-0,0012 \\
(-0,049)\end{array}$ & $\begin{array}{l}-0,0107 \\
(-0,439)\end{array}$ & $\begin{array}{l}-0,0012 \\
(-0,049)\end{array}$ \\
\hline INSTITUC & $\begin{array}{l}-0,0005 \\
(-0,471) \\
\end{array}$ & $\begin{array}{l}0,0002 \\
(0,256) \\
\end{array}$ & $\begin{array}{l}-0,0005 \\
(-0,471) \\
\end{array}$ \\
\hline LN_AT & $\begin{array}{l}-0,0539 \\
(-3,207)\end{array}$ & $\begin{array}{l}0,0939 \\
(1,032)\end{array}$ & $\begin{array}{l}-0,0539 \\
(-3,207)\end{array}$ \\
\hline DIV_AT & $\begin{array}{l}0,1655 \\
(1,177)\end{array}$ & $\begin{array}{l}0,1327 \\
(0,361)\end{array}$ & $\begin{array}{l}0,1655 \\
(1,177)\end{array}$ \\
\hline VM_PL & $\begin{array}{l}0,0028 \\
(1,168)\end{array}$ & $\begin{array}{l}0,0009 \\
(0,387) \\
\end{array}$ & $\begin{array}{l}0,0028 \\
(1,168)\end{array}$ \\
\hline LOSS & $\begin{array}{l}-0,0275 \\
(-0,419) \\
\end{array}$ & $\begin{array}{c}-0,0065 \\
(-0,264) \\
\end{array}$ & $\begin{array}{l}-0,0275 \\
(-0,419) \\
\end{array}$ \\
\hline $\mathbf{R}^{2}$ AJUST. & $28,8 \%$ & $11,1 \%$ & $28,8 \%$ \\
\hline PROB. (F) & 0,000 & 0,000 & 0,000 \\
\hline No. de observações & 864 & 864 & 864 \\
\hline No. de empresas & 216 & 216 & 216 \\
\hline \multicolumn{4}{|c|}{$\begin{array}{l}\text { A variável dependente é representada por AD (accruals discricionários) e os } \\
\text { dados são relativos aos anos de } 2004 \text { a } 2007 \text {. Os números em parênteses } \\
\text { indicam a estatística } t \text { para a regressão pelo método dos mínimos quadrados } \\
\text { ordinários (MQO) e do procedimento de efeitos fixos (EF) e a estatística } z \text { no } \\
\text { caso do procedimento de efeitos aleatórios (EA). A significância estatística } \\
\text { nos níveis } 5 \% \text { e } 10 \% \text { é representada por ***, ** respectivamente. Realizaram- } \\
\text { se regressões com a correção da heterocedasticidade dos resíduos. As demais } \\
\text { variáveis estão detalhadas no quadro 5. }\end{array}$} \\
\hline
\end{tabular}

Analisando-se a tabela 12, verifica-se que para todas as regressões (método dos Mínimos Quadrados Ordinários - MQO; método de estimação de Efeitos Fixos - EF; método de estimação de Efeitos Aleatório - EA) as estimativas dos coeficientes mostraram ausência de significância estatística para todas as variáveis calculadas, excetuando-se apenas os interceptos de MQO e EA. 
Compararam-se as estimações calculadas pelo método MQO com o método EA utilizando-se o teste de Breusch-Pagan. Em seguida, testaram-se o método EF com o método EA por meio do teste de Hausman. No primeiro caso, a hipótese nula de que os efeitos específicos não são relevantes foi rejeitada, indicando que o método EA é mais indicado que MQO; no segundo caso, o teste indicou que os estimadores tanto pelo método MQO quanto pelo método EA podem ser inconsistentes, sugerindo-se a utilização do método EF para as inferências estatísticas.

De qualquer forma, pelos resultados encontrados, não há evidência do relacionamento da variável gerenciamento de resultados $(\mathrm{AD})$ e das demais variáveis de governança corporativa relacionadas ao conselho de administração (CEO, TAM_ADM, IND_DIR_ADM) e controle acionário (ACION_MAJOR, DIR_MAJOR, INSTITUC), resultado, este, diferente do encontrado na literatura internacional. A divergência de resultados pode estar associada ao controle acionário das empresas listadas em bolsa de valores no Brasil, o qual é altamente concentrado em poucos acionistas. Conforme estudo da Mckinsey (2000), 95\% das empresas listadas na BOVESPA têm o capital votante concentrado em três ou menos acionistas, o que pode ser considerado um sinal de má governança (Lopes, 2008). 


\section{CONSIDERAÇÕES FINAIS}

O objetivo principal desta tese foi verificar se a existência de conselho fiscal nas empresas brasileiras de capital aberto influencia no nível de gerenciamento de resultados praticados por estas, uma vez que referido órgão é responsável pela fiscalização dos atos dos administradores e deve oferecer sua opinião quanto aos demonstrativos financeiros examinados pelo auditor externo. Dessa forma, sua intersecção com práticas de governança corporativa e, consequientemente, com possíveis níveis de gerenciamento de resultados é evidente.

Ademais, estando a contabilidade intimamente ligada aos mecanismos de governança corporativa, uma vez que os investidores deveriam confiar na situação econômica da empresa relatada pelos relatórios contábeis, analisou-se como objetivo secundário se a formação em ciências contábeis dos conselheiros também estaria relacionada a menores níveis de gerenciamento de resultados pelas empresas.

Também foi verificado se outros instrumentos de governança corporativa teriam efeitos no nível de gerenciamento de resultados, tais como existência de "índice de governança Bovespa"; investidores institucionais; comitê de auditoria; composição do board; direitos dos acionistas; evidenciação; empresa de auditoria externa.

O presente estudo utilizou-se do modelo de Jones (1991) e das métricas de Leuz et al (2002) para o cálculo de gerenciamento de resultados, sendo as análises realizadas com base em regressões lineares simples e análise de dados em painel (utilizando as técnicas de efeitos fixos e de efeitos aleatórios) nas quais as variáveis dependentes foram representadas pelas métricas de gerenciamento de resultados e as variáveis independentes, pelos componentes de governança corporativa, sendo as hipóteses testadas em termos dos coeficientes encontrados.

A pesquisa estatística foi dividida em duas partes: a primeira com o propósito de analisar o relacionamento do conselho fiscal e demais instrumentos de governança corporativa com as métricas de gerenciamento de resultados fazendo-se uso das métricas de Leuz et al (2002); a segunda teve o propósito de verificar se os resultados de estudos que fizeram uso de 
instrumentos de governança realizados em outros países teriam conclusões similares se aplicados ao Brasil e, neste caso, aplicando-se o modelo modificado de Jones (1991).

$\mathrm{Na}$ primeira parte da pesquisa, pelas regressões realizadas, foi possível encontrar um relacionamento positivo entre a existência de conselho fiscal e menores níveis de gerenciamento de resultados. Analisando-se isoladamente a variável que retrata a formação em ciências contábeis, ora foi demonstrado que referida formação implicaria em maiores gerenciamentos de resultados (variável dependente EM1), ora foi demonstrado que a especialização indicaria menores níveis de gerenciamento de resultados (variável dependente EM2).

Contudo, por intermédio de outras duas variáveis, quer sejam, a existência de índice de governança da BOVESPA (GOVERN) e a existência de conselho fiscal com especialista em ciências contábeis (CF_EXP), foi possível verificar relacionamento com menores níveis de gerenciamento de resultados, sugerindo, assim, que quando a empresa tem um processo de governança corporativa mais estruturada, a especialidade dos conselheiros é item diferencial para a melhoria da informação contábil divulgada.

Quanto às demais variáveis, de um modo geral, estas não demonstraram nas regressões estatísticas realizadas níveis significantes de relacionamento com gerenciamento de resultados. Contudo, quando analisadas em conjunto por meio da análise de clusters, foi possível identificar que empresas com menores índices de gerenciamento de resultados possuíam os mecanismos de governança corporativa aqui estudados, quer sejam, conselho fiscal, investidores institucionais, melhores disclosures, ADRs, conselheiros independentes, realização de reuniões do conselho fiscal com freqüência mínima e auditoria independente realizada por grandes empresas.

Em relação à segunda parte da pesquisa, os resultados encontrados sugerem que não há evidência de relacionamento da variável gerenciamento de resultados (AD) e das demais variáveis de governança corporativa relacionadas ao conselho de administração (CEO, TAM_ADM, IND_DIR_ADM) e controle acionário (ACION_MAJOR, DIR_MAJOR, INSTITUC). Ressalta-se que na literatura internacional, conforme comentado nos demais capítulos desta tese, os resultados são diferentes e demonstram relacionamento. A divergência 
de resultados pode estar associada ao controle acionário das empresas listadas em bolsa de valores no Brasil, o qual é altamente concentrado em poucos acionistas.

Considerando-se a pesquisa como um todo é possível inferir que os instrumentos de governança corporativa, em conjunto, são diferenciais entre as empresas que administram em menores níveis seus resultados e, conseqüentemente, fornecem às partes interessadas melhores informações sobre a real situação da empresa. Nesse sentido, destaque deve ser dado ao conselho fiscal que demonstrou estar relacionado com informações contábeis de melhor qualidade.

Por fim, faz-se importante acrescentar que vários outros fatores podem contribuir na redução de práticas de gerenciamento de resultados e na diminuição da assimetria informacional para o mercado de capitais, entre eles, a ética das empresas e de seus altos executivos, o gerenciamento de riscos e a estrutura de controles internos, a efetividade do comitê de auditoria, a capacitação dos auditores externos, a fiscalização e a respectiva punição que se fizer necessária pelos órgãos reguladores, sendo importante a realização de futuras pesquisas relacionando-os com informações contábeis fidedignas. O relacionamento de altos níveis de gerenciamento de resultados e crises financeiras presenciadas pelo mercado em algumas grandes empresas também poderiam ser alvo de pesquisas posteriores, com o intuito de verificar possibilidades de previsões e tendências corporativas. 


\section{REFERÊNCIAS}

ABBOTT, L. J.; PARKER, S.; PETERS, G. F. Audit committee characteristics and restatement. Auditing: A Journal of Practice \& Theory, n. 23, p. 69-87, 2004.

AMERICAN INSTITUTE OF CERTIFIED PUBLIC ACCOUNTANTS. Statement on auditing standard $n^{\circ} 29$ - internal control. 1958. Disponível em <http://www.aicpa.org>. Acesso em: 12/12/2007.

. Statement on auditing standard $n^{\circ} 55$ - consideration of internal control in a financial statement audit. 1988. Disponível em <http://www.aicpa.org>. Acesso em: 12/12/2007.

Statement on auditing standard $n^{\circ} 78$ - consideration of internal control in a financial statement audit: an amendment to statement on auditing standard. 1995. Disponível em <http://www.aicpa.org>. Acesso em: 12/12/2007.

AMAT, Oriol et al. The ethics of creative accounting: some Spanish evidence. Working Paper. Disponível em <http://www.ssrn.com>. Acesso em: 23/11/2007.

ANDRADE, Adriana; ROSSETTI, José P. Governança corporativa: fundamentos, desenvolvimento e tendências. 2. ed. São Paulo: Atlas, 2006.

ANDREZO, Andrea Fernandes; LIMA, Iran Siqueira. Mercado financeiro: aspectos históricos e conceituais. 2. ed. São Paulo: Thomson, 2002.

ANTUNES, Jerônimo. Contribuição ao estudo da avaliação de risco e controles internos na auditoria de demonstrações contábeis no Brasil. São Paulo, 1998. Dissertação (Mestrado em Controladoria e Contabilidade) - Programa de Pós-Graduação em Ciências Contábeis, Departamento de Contabilidade e Atuária, Faculdade de Economia, Administração e Contabilidade da Universidade de São Paulo.

ALMEIDA, Marcelo Cavalcanti. Auditoria: um curso moderno e completo. São Paulo: Atlas, 1996.

ATTIE, Willian. Auditoria interna. São Paulo: Atlas, 1992.

BARNHILL, Theodore M. J.; GLEASON, Katherine. O novo acordo da Basiléia: a importância de estrutura conceitual. Resenha BM\&F, São Paulo, n. 150, p. 33-44, 2002.

BARTON, Jan. Does the use of financial derivatives affect earnings management decisions? The University of Alabama, Jan. 2000. Disponível em <http://www.ssrn.com>. Acesso em: 23/11/2007. 
BARTOV, Eli; GUL, Ferdinand A.; TSUI, Judy S. L. Discretionary-accruals models and audit qualifications. Working Paper, 2000, New York University and City University of Hong Kong. Disponível em <http://www.ssrn.com>. Acesso em: 01/07/2008.

BASLE COMMITTEE ON BANKING SUPERVISION. Amendment to the capital accord to incorporate market risks. Basle: Bank for International Settlement, January 1996. Disponível em <http://www.bis.org/publ/bcbs24.pdf>. Acesso em: 09/05/2003.

A new capital adequacy framework. Basle: Bank for International Settlement, June 1996. Disponível em <http://www.bis.org/publ/bcbs50.pdf>. Acesso em: 09/05/2003.

A new capital adequacy framework: pillar 3 - market discipline. Basle: Bank for International Settlement, January 2000. Disponível em <http://www.bis.org/publ/bcbs65.pdf>. Acesso em: 09/05/2003.

Core principles for effective banking supervision. Basle: Bank for International Settlement, September 1997. Disponível em <http://www.bis.org/publ/bcbs30a.pdf>. Acesso em: 09/05/2003.

Enhancing bank transparency. Basle: Bank for International Settlement, September 1998. Disponível em <http://www.bis.org/publ/bcbs41.pdf>. Acesso em: 09/05/2003.

International convergence of capital measurement and capital standards. Basle: Bank for International Settlement, July 1988. Disponível em <http://www.bis.org/publ/bcbs04A.pdf>. Acesso em: 09/05/2003.

Overview of the new Basle capital accord. Basle: Bank for International Settlement, January 2001. Disponível em <http://www.bis.org/publ/bcbsca02.pdf>. Acesso em: 09/05/2003.

Overview of the amendment to the capital accord to incorporate market risks. Basle: Bank for International Settlement, January 1996. Disponível em <http://www.bis.org/publ/bcbs23.pdf>. Acesso em: 09/05/2003.

Pillar 2: supervisory review process [consultive document]. Basle: Bank for International Settlement, January 2001. Disponível em <http://www.bis.org/publ/bcbsca08.pdf>. Acesso em: 09/05/2003.

Pillar 3: market discipline [consultive document]. Basle: Bank for International Settlement, January 2001. Disponível em <http://www.bis.org/publ/bcbsca10.pdf >. Acesso em: 09/05/2003. 
Press release: Basel Committee reaches agreement on new Basel capital accord.

Basle: Bank for International Settlement, July 2002. Disponível em <http://www.bis.org/press/p020710.htm>. Acesso em: 09/05/2003.

Press release: progress towards completion of the new Basel capital accord. Basle: Bank for International Settlement, December 2001. Disponível em <http://www.bis.org/press/p011213.htm>. Acesso em: 09/05/2003.

Press release: update on the new Basel capital accord. Basle: Bank for International Settlement, June 2001. Disponível em <http://www.bis.org/press/p010625.htm>. Acesso em: 09/05/2003.

Public disclosures by banks: results of the 1999 disclosure survey. Basle: Bank for International Settlement, April 2001. Disponível em <http://www.bis.org/publ/bcbs80.pdf>. Acesso em: 09/05/2003.

Public disclosures by banks: results of the 2000 disclosure survey. Basle: Bank for International Settlement, May 2002. Disponível em <http://www.bis.org/publ/bcbs90.pdf>. Acesso em: 09/05/2003.

Public disclosures by banks: results of the 2001 disclosure survey. Basle: Bank for International Settlement, May 2003. Disponível em <http://www.bis.org/publ/bcbs97.pdf〉. Acesso em: 08/09/2003.

The 2002 Loss Data Collection Exercise for Operational Risk: Summary of the Data Collected. Basle: Bank for International Settlement, March 2003. Disponível em < http://www.bis.org/bcbs/qis/ldce2002.pdf >. Acesso em: 15/12/2003.

The new Basel capital accord [consultive document]. Basle: Bank for International Settlement, January 2001. Disponível em <http://www.bis.org/publ/bcbsca03.pdf >. Acesso em: 09/05/2003.

The new Basle capital accord: an explanatory note. Basle: Bank for International Settlement, January 2001. Disponível em <http://www.bis.org/publ/bcbsca01.pdf >. Acesso em: 09/05/2003.

The relationship between banking supervisors and banks' external auditors. Basle: Bank for International Settlement, January 2002. Disponível em <http://www.bis.org/publ/bcbs87.pdf>. Acesso em: 09/05/2003.

Working paper on pillar 3: market discipline. Basle: Bank for International Settlement, September 2001. Disponível em <http://www.bis.org/publ/bcbs_wp7.pdf>. Acesso em: 09/05/2003. 
BEASLEY, Mark; SALTERIO, Steven. The relationship between board characteristics and voluntary improvements in audit committee composition and experience. Working Paper. Disponível em <http://www.ssrn.com>. Acesso em: 01/07/2008.

BEAVER, W. H. Financial reporting: an accounting revolution. Prentice Hall, 1981.

BÉDARD, J.; CHTOUROU, S. M.; COURTEAU, L. The effect of audit committee expertise, independence, and activity on aggressive earnings management. Auditing: A Journal of Practice \& Theory, v. 2, n. 23, p. 13-35, 2004.

BERNHOEFT, R.; GALLO, M. Governança na empresa familiar. 4. ed. Rio de Janeiro: Elsevier, 2003.

BLUE RIBBON COMMITTEE. Improving the effectiveness of corporate audit committees. New York: NASD, 1999.

BOLSA DE VALORES DE SÃO PAULO - BOVESPA. Folhetos do novo mercado e níveis diferenciados de governança corporativa. Disponível em <http://www.bovespa.com.br>. Acesso em: 25/11/2007.

. Resolução $\mathbf{n}^{\circ}$ 282/02-CA. Dispõe acerca do registro na Bolsa de Valores de São Paulo de companhias abertas. Disponível em <http://www.bovespa.com.br>. Acesso em: 25/11/2007.

BRAGA, Roberto. Fundamentos e técnicas de administração financeira. São Paulo: Atlas, 1995.

BRASIL. Lei n. 6.404, de 15/12/1976 . Disponível em <http://www.planalto.gov.br>. Acesso em: 25/11/2007.

Lei n. 10.406, de 10/01/2002 . Disponível em <http://www.planalto.gov.br>. Acesso em: 25/11/2007.

Lei n. 11.638, de 28/12/2007 . Disponível em <http://www.planalto.gov.br>. Acesso em: 25/11/2007.

BRADBURY, M. E.; MAK, Y. T., TAN, S. M. Board Characteristics, audit committee characteristics and abnormal accruals. Working Paper, 2004. Disponível em <http://www.ssrn.com>. Acesso em: 01/07/2008.

BRICKLEY, J. A.; COLES, J. L.; TERRY, R. L. Outside directors and the adoption of poison pills. Journal of Financial Economics. n. 35, p. 371-391, 1994. 
BRIGHAM, Eugene F. Fundamentos da moderna administração financeira. 3. ed. Rio de Janeiro: 1999.

BRITO, Osias Santana de. Contribuição ao estudo de modelo de controladoria de riscoretorno em bancos de atacado. São Paulo, 2000. Tese (Doutorado em Controladoria e Contabilidade) - Programa de Pós-Graduação em Ciências Contábeis, Departamento de Contabilidade e Atuária, Faculdade de Economia, Administração e Contabilidade da Universidade de São Paulo.

BROWN, Lawrence D.; CAYLOR, Marcus L. Corporate governance and firm performance. Journal of Accounting and Public Policy. v. 25, n. 4, 2006.

BURGSTAHLER, David C.; DICHEV, I. Earnings management to avoid earnings decreases and losses. Journal of Accounting and Economics, v. 24, p. 99-129, 1997.

BURGSTAHLER, David C.; EAMES, Michael J. Earnings management to avoid losses and earnings decreases: are analysts fooled? Contemporary Accounting Research, v. 20, n. 2, p. 253-294, 2003.

CAOUETTE, John B. Gestão do risco de crédito - o próximo grande desafio financeiro. São Paulo: Qualitymark, 2000.

CARCELLO, Joseph V.; HOLLINGSWORTH, Carl W.; KLEIN, April; NEAL, Terry L. Audit committee financial expertise, competing corporate governance mechanisms and earnings management. Working Paper, 2006. Disponível em <http://www.ssrn.com>. Acesso em: 11/03/2008.

CARVALHAL-DA-SILVA, A. L.; LEAL, R. P. C. Corporate governance index: firm valuation and performance in Brazil. Revista Brasileira de Finanças, v. 3, n. 1, p. 1-18, 2005.

CARVALHO, Antonio Gledson de. Efeitos da migração para os níveis de governança da Bovespa. Jan. 2003. Disponível em <http://www.bovespa.com.br>. Acesso em: 23/11/2007.

CARVALHO, Luiz Nelson Guedes de. Uma contribuição à auditoria do risco de derivativos. São Paulo, 1996. Tese (Doutorado em Contabilidade) - Programa de PósGraduação em Ciências Contábeis, Departamento de Contabilidade e Atuária, Faculdade de Economia, Administração e Contabilidade da Universidade de São Paulo.

CARVALHO, Luiz Nelson Guedes de; TRAPP, Adriana Cristina G.; CHAN, Betty Lilian. Disclosure e risco operacional: uma abordagem comparativa em instituições financeiras que atuam no Brasil, na Europa e nos Estados Unidos. Revista de Administração, v. 39, n. 3, p. 264-273, 2004. 
CARVAlHOSA, Modesto. Comentários à lei de Sociedades Anônimas. 3. ed. São Paulo: Saraiva, 2003, v. 2 e 3.

CARvalHOSA, Modesto; LATORRACA, Milton. Comentários à lei de sociedades anônimas. São Paulo: Saraiva, 1997, v. 2 e 3.

CATELLI, Armando. Controladoria: uma abordagem da gestão econômica. 2. ed. São Paulo: Atlas, 2001.

CHAPMAN, Chris; WARD, Stephen. Project risk management - processes, techniques and insights. Chichester: Wiley, 1997.

CHTOUROU, Sonda M.; BÉDARD, Jean; COURTEU, Lucie. Corporate governance and earnings management. Disponível em <http://www.ssrn.com>. Acesso em: 14/07/2008.

COLLIN, Peter; JOLIFFE. Dictionary of accounting. Cambridge: Peter Collin Publishing, 1998.

COMISSÃO DE VALORES MOBILIÁRIOS. Recomendações da CVM sobre governança corporativa. Disponível em <http://cvm.gov.br>. Acesso em: 26/06/2008.

COMPTON, Eric N. Princípios das atividades bancárias. 3. ed. São Paulo: IBCB, 1990.

CONSELHO FEDERAL DE CONTABILIDADE. Resolução n. 750, de 29/12/1993. Disponível em <http://www.cfc.org.br>. Acesso em: 27/11/2007.

. Resolução n. 820, de 17/12/1997. Disponível em <http://www.cfc.org.br>. Acesso em: $27 / 11 / 2007$.

CONSELHO MONETÁRIO NACIONAL. Resolução n. 2.099, de 26/08/1994. Disponível em <http://www.bacen.gov.br>. Acesso em: 27/11/2007.

Resolução n. 2.138, de 29/12/1994. Disponível em <http://www.bacen.gov.br>. Acesso em: 27/11/2007.

. Resolução n. 2.139, de 29/12/1994. Disponível em <http://www.bacen.gov.br>. Acesso em: 27/11/2007.

Resolução n. 2.390, de 22/05/1997. Disponível em <http://www.bacen.gov.br>. Acesso em: 27/11/2007.

. Resolução n. 2.399, de 25/06/1997. Disponível em <http://www.bacen.gov.br>. Acesso em: 27/11/2007. 
Resolução n. 2.543, de 26/08/1998. Disponível em <http://www.bacen.gov.br>. Acesso em: 27/11/2007.

. Resolução n. 2.554, de 29/09/1998. Disponível em <http://www.bacen.gov.br>. Acesso em: 27/11/2007.

Resolução n. 3.198, de 27/05/2004. Disponível em <http://www.bacen.gov.br〉. Acesso em: 27/11/2007.

Resolução n. 3.380, de 29/06/2006. Disponível em <http://www.bacen.gov.br>. Acesso em: 27/11/2007.

. Resolução n. 3.444, de 28/02/2007. Disponível em <http://www.bacen.gov.br>. Acesso em: 27/11/2007.

. Resolução n. 3.503, de 26/10/2007. Disponível em <http://www.bacen.gov.br〉. Acesso em: 27/11/2007.

CONSELHO NACIONAL DE SEGUROS PRIVADOS. Resolução n. 118, de 22/12/2004. Disponível em <http://www.susep.gov.br>. Acesso em: 27/11/2007.

COOMBES, Paul; WONG, Chiu-Yin. Chairman and CEO: one job or two? The Mckinsey Quartely, n. 02, 2004.

COX, D. R; SNELL, E.J. Analysis of binary data.. 2. ed. New York: Chapman and Hall, 1989.

CROUHY, Michael et al. Risk Management. New York: McGraw-Hill, 2001.

CROXTON, Frederick E.; COWDEN, Dudley J. Estatística geral e aplicada. Rio de Janeiro: IBGE, 1952.

DeANGELO, Linda. Accounting numbers as market valuation substitutes: a study of management buyouts of public shareholders. The Accounting Review. n. 61, p. 400-420, 1986.

DECHOW, Patricia; SLOAN, Richard G. Executive incentives and the horizon problem: an empirical investigation. Journal of Accounting and Economics. n. 14, p. 51-89, 1991.

DECHOW, Patricia; SLOAN, Richard G.; HUTTON, Amy P. Detecting earnings management. The Accounting Review, v. 70, n. 2, p. 193-225, apr. 1995. 
DECHOW, Patricia; SLOAN, R. G.; SWEENEY, A. P. Causes and consequences of earnings manipulation: na analysis of firms subject to enforcement actions by the SEC.. Contemporary Accounting Reserch, n. 13, p. 1-36, 1996.

DECHOW, Patricia; DICHEV, I. D. The quality of accruals and earnings: the role of accrual estimation errors. The Accounting Review, v. 77, p. 35-59, apr. 2002.

DECHOW, Patricia; SKINNER, Douglas J. Earnings management: reconciling the views of accounting academics, practitioners, and regulators. Financial Reporting Issues Conference, feb. 2000.

DEFOND, M. L.; JIAMBALVO, J. Debt covenant violation and manipulation of accruals Journal of Accounting and Economics, v. 3, n. 66, p. 145-176, 1994.

DEFOND, M. L.; HANN, R.N; HU, X. Does the market value financial expertise on audit committees of board of directors? Journal of Accounting Reserch, v. 2, n. 43, p. 153-193, 2005.

DEGEORGE, F.; PATEL, J.; ZECKHAUSER, R. Earnings manipulation to exceed thresholds. Journal of Business, v.72, p. 1-33, 1999.

DELOACH, Jame W. Administração corporativa de risco: estratégias para relacionar risco e oportunidade. New York: Pearson Education, 2001.

DHALIWAL, Dan; NAIKER, Vic; NAVISSI, Farshid. Audit committee financial expertise, corporate governance and accruals quality: an empirical analysis. Working Paper, University of Arizona, 2006. Disponível em <http://www.ssrn.com>. Acesso em: 12/03/2008.

DIONNE, Georges; TRIKI, Thouraya. Risk management and corporate governance: the importance of independence and financial knowledge for the board and the audit committee. Working Paper, 2005. Disponível em <http://www.ssrn.com>. Acesso em: $12 / 03 / 2008$.

DOWD, Kevin. Beyond value at risk: the new science of risk management. Chichester: Wiley, 1999.

DRAGOMIR, Voicu-Dan. Highlights for a history of corporate governance. The Academy of Economic Studies of Bucharest, European Journal of Management, 2008. Disponível em <http://www.ssrn.com>. Acesso em: 03/01/2009.

DUARTE, Antonio Marcos J. et al. Gerenciamento de riscos operacionais e sua evolução no mercado financeiro brasileiro. Resenha BM\&F, São Paulo, n. 146, 07-09/2001. 
DUARTE, Antonio Marcos J. et al. Controles internos e gestão de riscos operacionais em instituições financeiras brasileiras: classificação, definições e exemplos. Resenha BM\&F, São Paulo, n. 143, 01-02/2001.

EDWARDS, Edgar O.; BELL, Philip W. The theory and measurement of business income. 7. ed. Los Angeles: University of California, 1973.

EISENHARDT, K. M. Agency theory: an assessment and review. Academy of Management Review, vol 14, n. 1, p. 57-74, 1989.

FASB, Financial Accounting Standards Board. Statement of financial accounting concepts n. 2. 1980.

ESCUDER, Sérgio A. Loureiro. Governança corporativa e o conselho fiscal como instrumento de geração de valor aos acionistas. Santos, 2006. Dissertação (Mestrado em Gestão de Negócios) Universidade Católica de Santos.

FERREIRA, Aurélio Buarque de Holanda. Novo Aurélio - século XXI - dicionário da Língua Portuguesa. 3. ed. São Paulo: Nova Fronteira, 1999.

FROST, Chris et al. Operational risk and resilience: understanding and minimizing operational risk to secure shareholder value. Oxford: PricewaterhouseCoopers, 2001.

GIL, Antonio Carlos. Como elaborar projetos de pesquisa. São Paulo: Atlas, 1987.

GITMAN, Lawrence J. Princípios de administração financeira. 7. ed. São Paulo: Harbra, 1997.

GONCHAROV, Igor; ZIMMERMANN, Jochen. Do accounting standards influence the level of earnings management? Evidence from Germany. Working Paper n. 41, 2003. Disponível em <http://www.ssrn.com>. Acesso em: 23/11/2007.

HAIR, Joseph F. Jr. et al. Análise multivariada de dados. Porto Alegre: Bookman, 2005.

HEALY, Paul. M. The effect of bonus schemes on accounting decisions. Journal of Accounting \& Economics, vol 7, p. 85-112, apr. 1985.

HEALY, Paul M.; WAHLEN, James M. A review of the earnings management literature and its implications for standard setting. Nov. 1998. Disponível em <http://www.ssrn.com>. Acesso em: 23/11/2007.

HENDRIKSEN, Eldon S.; BREDA, Michael F. Van. Teoria da Contabilidade. 5. ed. São Paulo: Atlas, 1999. 
HOSMER, David W. Jr.; LEMESHOW, Stanley. Applied Logistic Regression.. New York: John Wiley \& Sons, 1989.

HULL, John. Introdução aos mercados futuros e de opções. 2. ed. São Paulo: BM\&F, 1996.

IBGC - Instituto Brasileiro de Governança Corporativa; BOOZ-ALLEN-HAMILTON. Panorama atual da governança corporativa no Brasil. São Paulo: IBGC, 2002.

Código das Melhores Práticas de Governança Corporativa. São Paulo: IBGC, 2003. Disponível em <http://www.ibgc.org.br>. Acesso em: 25/11/2007.

IUDÍCIBUS, Sérgio de. Teoria da Contabilidade. 5. ed. São Paulo: Atlas, 1997.

IUDÍCIBUS, Sérgio de; LOPES, Alexsandro Broedel. Teoria avançada da Contabilidade. São Paulo: Atlas, 2004.

JENSEN, Michael. The modern industrial revolution, exit, and the failure of internal control systems. The Journal of Finance, v. 3, n. 25, p. 831-873, 1993.

JENSEN, Michael. Theory of the firm: governance, residual claims, and organizational forms. Harvard University Press, 2001.

JENSEN, Michael; MECKLING, William. Theory of the firm: managerial behaviour, agency costs and ownership structures. Journal of Financial Economics, v. 3, p. 305-360, oct. 1976.

JONES, Jennifer. Earnings management during import relief investigations. Journal of Accounting Research, n. 29, p. 193-228, 1991.

KENYON, Alfred. Currency risk management. Chichester: Wiley, 1981.

KING, Jack L. Operational risk: measurement and modeling. London: Wiley, 2001.

LACERDA, J. C. Sampaio de. Manual das sociedades por ações. Rio de Janeiro: Freitas Bastos, 1967.

LALLEY, Edward P. Corporate uncertainty \& risk management. New York: Risk Management Society, 1982.

LEUZ, Christian et al. Investor protection and earnings management: an international comparison. Journal of Financial Economics, v. 69, 2003.

LEVITT, Arthur Jr. The “numbers game”. The CPA Journal, v. 68, n. 12, Dec. 1998. 
LIMA, Iran Siqueira; LOPES, Alexsandro Broedel. Contabilidade e controle de operações com derivativos. São Paulo: Pioneira, 1999.

LIU, Caixing. The Sarbanes-Oxley Act and mitigation of earnings management. Hawaií, 2004. Dissertation (Doctorate of Philosophy) - Division of University of Hawaií.

LIU, Min-Hsin Carol. The association of audit committee oversight with corporate disclosure quality. New York, 2005. Dissertation (Doctorate of Philosophy) - Department of Accounting and Law of University of New York.

LODI, João Bosco. Conselho de administração. São Paulo: Livraria Pioneira, 1988.

LOPES, Alexsandro Broedel. A relevância da informação contábil para o mercado de capitais: o modelo de Ohlson aplicado à Bovespa. São Paulo, 2001. Tese (Doutorado em Controladoria e Contabilidade) - Programa de Pós-Graduação em Ciências Contábeis, Departamento de Contabilidade e Atuária, Faculdade de Economia, Administração e Contabilidade da Universidade de São Paulo.

LOPES, Alexsandro Broedel. The relation between firm-specific corporate governance, cross-listing and the informativeness of accounting numbers in Brazil. Manchester, 2008. Thesis (Doctor of Philosophy Degree in the Faculty of Humanities) - Manchester Business School, University of Manchester.

LOPES, Alexsandro Broedel. Corporate governance and financial accounting. In: Manchester Business School, p. 1-84, 2008.

LOPES, Alexsandro Broedel; MARTINS, Eliseu. Teoria da contabilidade: uma nova abordagem. São Paulo: Atlas, 2005.

MAISEL, Sherman. Risk and capital adequacy in commercial banks. Chicago: National Bureau of Economic Research, 1981.

MAROCO, João. Análise estatística com a utilização do SPSS. 2. ed., Lisboa: Sílabo, 2003.

MARSHALL, Christopher. Measuring and managing operational risks in financial institutions. England: Wiley, 2001.

MARTINEZ, Antonio Lopo. "Gerenciamento" dos resultados contábeis: estudo empírico das companhias abertas brasileiras. São Paulo, 2001. Tese (Doutorado em Controladoria e Contabilidade) - Programa de Pós-Graduação em Ciências Contábeis, Departamento de Contabilidade e Atuária, Faculdade de Economia, Administração e Contabilidade da Universidade de São Paulo. 
MARTINS, Gilberto de Andrade. Manual para elaboração de monografias e dissertações. 2. ed., São Paulo: Atlas, 1994.

MCKINSEY e KORN-FERRY. Panorama da governança corporativa no Brasil. São Paulo: Mckinsey \& Company e Korn-Ferry International, 2002.

MENARD, Scott. Applied Logistic Regression Analysis.. 2. ed. California: Sage Publications, 2001, v. 106.

MILONE, Mário César de Mattos; FAMÁ, Rubens. Avaliação de risco: modelos simplificados de var ao alcance de investidores não-institucionais. In: V SEMINÁRIO EM ADMINISTRAÇÃO FEA-USP - SEMEAD, 2001, São Paulo: SEMEAD, 2001.

MORGAN, Gareth. Imagens da organização. São Paulo: Atlas, 1996.

MOHANRAM, Partha S. How to manage earnings management?. Accounting World, Oct. 2003. Disponível em <http://www.ssrn.com>. Acesso em: 23/11/2007.

MOSIMANN, Clara Pellegrinello; FISCH, Silvio. Controladoria seu papel na administração de Empresas. 2. ed. São Paulo: Atlas, 1999.

MULFORD, Charles W.; COMISKEY, Eugene E. The financial numbers game: detecting creative accounting practices. New York: John Willey Trade, 2002.

MYERS, James N. et al. Earnings momentum and earnings management. Working Paper. Disponível em <http://www.ssrn.com>. Acesso em: 23/11/2007.

NETO, Alexandre Assaf. Estrutura e análise de balanços: um enfoque econômicofinanceiro. 8. ed. São Paulo: Atlas, 2007.

NIERO, Nelson; ROCCO, Nelson. Efeito da refis causa polêmica. Valor Econômico. São Paulo, 19/07/2000.

OCDE. OCDE principles of corporate governance. Paris: OCDE, 2004.

OLIVEIRA, Alexandre Queiroz de. O rodízio de firmas de auditoria e seus impactos nas demonstrações contábeis. São Paulo, 2005. Dissertação (Mestrado) - Pontifícia Universidade Católica de São Paulo.

ORSOLINI, Rogério. Alocação de capital - um enfoque de avaliação de desempenho ajustado ao risco em bancos. São Paulo, 2000. Dissertação (Mestrado em Controladoria e Contabilidade) - Programa de Pós-Graduação em Ciências Contábeis, Departamento de 
Contabilidade e Atuária, Faculdade de Economia, Administração e Contabilidade da Universidade de São Paulo.

PARFET, Willian. U. Accounting subjectivity and earnings management: a preparer perspective. Accounting Horizons, v. 14, n. 4, Dec. 2004.

PAYNE, J. L.; ROBB, Sean W. G. Earnings management: the effect of ex ante earnings expectations. Journal of Accounting, Auditing and Finance, v. 15, 2000.

PAXSON, Dean; WOOD, Douglas. Encyclopedic Dictionary of finance. Cambridge: Blackwell Publishers, 1998.

PEASNELL, K. V.; POPE, P. F.; YOUNG, S. Board monitoring and earnings management: do outside directors influence abnormal accruals? Working Paper, Lancaster University, 2000. Disponível em <http://www.ssrn.com>. Acesso em: 14/07/2008.

PEDOTE, Cristiane F. S. Análise e gerenciamento de risco: gestão do risco operacional em instituições financeiras. São Paulo: Bolsa de Mercadorias \& Futuros, 2002.

PINCUS, M.; RAJGOPAL, S. The interaction between accrual management and hedging: evidence from oil and gas firms. The Accounting Review, v. 77, p. 127-160, 2002.

PRICEWATERHOUSECOOPERS. Risk Management Forecast: 2001. London: PricewaterhouseCoopers, 2001.

PUBLIC COMPANY ACCOUNTING OVERSIGHT BOARD. Auditing standard $\boldsymbol{n}^{\circ} 1-$ references in auditors' reports to the standard of the public company accounting oversight board. May, 2004. Disponível em <http://www.pcaobus.org>. Acesso em: 12/12/2007.

Auditing standard $n^{\circ} 2-$ An audit of internal control over financial reporting performed in conjunction with an audit of financial statements. Jun. 2004. Disponível em <http://www.pcaobus.org>. Acesso em: 12/12/2007.

Auditing standard $n^{\circ} 3$ - Audit documentation. Aug. 2004. Disponível em <http://www.pcaobus.org>. Acesso em: 12/12/2007.

Auditing standard $n^{\circ} 4$ - Reporting on whether a previously reported material weakness continues to exist. Feb, 2006. Disponível em <http://www.pcaobus.org>. Acesso em: 12/12/2007.

Auditing standard $n^{\circ} 5-A n$ audit of internal control over financial reporting that is integrated with an audit of financial statements. Jul, 2007. Disponível em <http://www.pcaobus.org>. Acesso em: 12/12/2007. 
RAJGOPAL, S. M. Venkatachalam; JIAMBALVO, J. Is institutional ownership associated with earnings management and the extent to which stock price reflect future earnings? Working Paper, University of Washington and Stanford University, 1999. Disponível em <http://www.ssrn.com>. Acesso em: 04/04/2008.

RAMOS, Michael. The Sarbanes-Oxley section 404 implementation toolkit: practice aids for managers and auditors. New Jersey: Wiley, 2005.

RODRIGUES, Raimundo Nonato. O acordo da Basiléia - um estudo da adequação de capital nas instituições financeiras brasileiras. São Paulo, 1998. Dissertação (Mestrado em Controladoria e Contabilidade) - Programa de Pós-Graduação em Ciências Contábeis, Departamento de Contabilidade e Atuária, Faculdade de Economia, Administração e Contabilidade da Universidade de São Paulo.

ROSS, Stephen A et al. Administração financeira. São Paulo: Atlas, 1995.

SANCHES, Marcos Venicio. Sistemas de controles internos e de fiscalização em demonstrações contábeis: uma análise crítica de normas específicas. São Paulo, 2007. Dissertação (Mestrado em Controladoria e Contabilidade) - Programa de Pós-Graduação em Ciências Contábeis, Departamento de Contabilidade e Atuária, Faculdade de Economia, Administração e Contabilidade da Universidade de São Paulo.

SAUNDERS, Anthony M. Administração de instituições financeiras. 2. ed. São Paulo: Atlas, 2000.

SANTOMERO, Anthony M. Commercial bank risk management: an analysis of the process. The Working Paper Series at The Wharton Financial Institutions Center. Pennsylvania: The Wharton School University, 1997. Disponível em <http://fic.wharton.uppen.edu/fic/papers/95/9511.pdf>. Acesso em: 25/11/2007.

SCHIPPER, Katherine. Commentary on earnings management. Accounting Horizons. Sarasota, v. 3, p. 91-102, dec. 1989.

SECURATO, José Cláudio. Uma década de governança corporativa. São Paulo: Saraiva, 2006.

SECURATO, José Roberto. Decisões financeiras em condições de risco. São Paulo: Atlas, 1993.

SECURATO, José Roberto; PEROBELLI, Fernanda Finotti Cordeiro. Avaliação do risco operacional: a proposição do Equity-at-risk. Anais do Encontro Brasileiro de Finanças, Rio de Janeiro, IBMEC, 2002. 
SECURITIES AND EXCHANGE COMISSION. Sarbanes-Oxley Act of 2002. Disponível em <http://www.sec.gov>. Acesso em: 12/12/2007.

SHIVDASANI, A. Board composition, ownership structure, and hostile takeovers. Journal of Accounting and Economics, n. 16, p. 167-198, 1993.

SHLEIFER, Andrew; VISHNY, Robert W. Large shareholders and corporate control. Journal of Political Economy, n. 95, p. 461-488, 1986.

1997.

A survey of corporate governance. The Journal of Finance, v. 52, n. 2, p. 737-783,

SILVA, José Anchieta da. Conselho fiscal nas sociedades anônimas brasileiras. Belo Horizonte: Del Rey, 2000.

SILVEIRA, Alexandre Di Miceli da. Governança corporativa, desempenho e valor da empresa no Brasil. São Paulo, 2002. Dissertação (Mestrado em Administração) - Programa de Pós-Graduação em Administração, Departamento de Administração, Faculdade de Economia, Administração e Contabilidade da Universidade de São Paulo.

SILVEIRA, Alexandre Di Miceli da. Governança corporativa e estrutura de propriedade: determinantes e relação com o desempenho das empresas no Brasil. São Paulo, 2004. Tese (Doutorado em Administração) - Programa de Pós-Graduação em Administração, Departamento de Administração, Faculdade de Economia, Administração e Contabilidade da Universidade de São Paulo.

SLOAN, R. Do stock prices fully reflect information in accrual and cash flows about future earnings? The Accounting Review, v. 71, p. 289-315, 1996.

SLOAN, R. Financial accounting and corporate governance: a discussion. Working Paper. Disponível em <http://www.ssrn.com>. Acesso em: 23/11/2007.

SOUZA, Milanez S. Governança no Brasil: perspectives no Brasil. Belém: Adcontar, v. 5, n. 1, p. 15-34, 2004.

STEVENSON, William J. Estatística aplicada à administração. São Paulo: Harbra, 1981.

STOCK, James H.; WATSON, Mark W. Econometria. São Paulo: Pearson, 2004.

STONE, Charles A., ZISSU, Anne. Global risk based capital regulations. Volume II: management and funding strategies. New York: Irwin, 1994. 
SUPERINTENDÊNCIA DE SEGUROS PRIVADOS. Circular n. 249, de 20/02/2004. Disponível em <http://www.susep.gov.br>. Acesso em: 27/11/2007.

Circular n. 280, de 30/12/2004. Disponível em <http://www.susep.gov.br>. Acesso em: 27/11/2007.

TEOH, Siew Hong; WELCH, Ivo; WONG, T. J. Earnings management and the underperformance of seasoned equity offerings. Journal of Financial Economics. Chicago, v. 50, p. 63-99, 1998.

THE COMMITTEE OF SPONSORING ORGANIZATIONS. Internal control - integrated framework. 1992. Disponível em <http://www.pcaobus.org>. Acesso em: 12/12/2007.

Enterprise risk management - integrated framework. 2004. Disponível em <http://www.pcaobus.org>. Acesso em: 12/12/2007.

TOLEDO, Paulo Fernando Campos Salles de. O conselho de administração na sociedade anônima. 2 ed. São Paulo: Atlas, 1999.

TRAPP, Adriana C. G. Estudo da avaliação e gerenciamento do risco operacional de instituições financeiras no Brasil: análise de caso de uma instituição financeira de grande porte. São Paulo, 2004. Dissertação (Mestrado em Controladoria e Contabilidade) Programa de Pós-Graduação em Ciências Contábeis, Departamento de Contabilidade e Atuária, Faculdade de Economia, Administração e Contabilidade da Universidade de São Paulo.

TUKAMOTO, Yhurika Sandra. Contribuição ao estudo do "gerenciamento" de resultados - uma comparação entre as companhias abertas brasileiras emissoras de ADRs e não emissoras de ADRs. São Paulo, 2000. Dissertação (Mestrado em Controladoria e Contabilidade) - Programa de Pós-Graduação em Ciências Contábeis, Departamento de Contabilidade e Atuária, Faculdade de Economia, Administração e Contabilidade da Universidade de São Paulo.

TURLEY, Stuart; ZAMAN, Mahbub. Audit committee effectiveness: informal processes and behavioural effects. Accounting, Auditing and Accountability Journal, v. 20, n. 5, p. 1-29, 2007.

VALVERDE, Trajano de M. Parecer: sociedade anônima. Exame de livros: conselho fiscal, responsabilidade civil dos diretores. Revista Forense. Rio de Janeiro, n. 137, p. 50$57,1959$.

VAUGHAN, Emmett. Fundamentals of risk and insurance. 6th ed. New York: John Wiley \& Sons, 1992. 
VICENTE, Ernesto Fernando Rodrigues. A estimativa do risco na constituição da PDD. São Paulo, 2001. Dissertação (Mestrado em Controladoria e Contabilidade) - Programa de Pós-Graduação em Ciências Contábeis, Departamento de Contabilidade e Atuária, Faculdade de Economia, Administração e Contabilidade da Universidade de São Paulo.

XAVIER, Paulo Henrique Moura. Transparência das demonstrações contábeis dos bancos no Brasil: estudo de caso sob a perspectiva do acordo "Basiléia 2". São Paulo, 2003. Dissertação (Mestrado em Controladoria e Contabilidade) - Programa de Pós-Graduação em Ciências Contábeis, Departamento de Contabilidade e Atuária, Faculdade de Economia, Administração e Contabilidade da Universidade de São Paulo.

XIE, Biao; DAVIDSON, Wallace N; DADALT, Peter J. Earnings management and corporate governance: the roles of the board and the audit committee. Disponivel em <http://www.ssrn.com>. Acesso em: 09/09/2008.

WARFIELD, T. D.; WILD, J. J., WILD, K. L. Managerial ownership, accounting choices and informativeness of earnings. Journal of Accounting and Economics. Sarasota, n. 20, p. 61-91, 1995.

WATTS, R. L.; ZIMMERMAN, J. L. Positive accounting theory. Englewood Cliffs: Prentice Hall, 1986.

WEILI, Ge; MCVAY, Sarah. The disclosure of material weakness in internal control after the Sarbanes-Oxley Act. Accounting Horizons. Sarasota, v. 19, n. 3, p. 137, sep. 2005.

WILD, J. The audit committee and earnings quality. Journal of Accounting, Auditing \& Finance, v. 11 n. 2, 247-276, 1996.

WILLIAMS, C. Arthur Jr. et al. Risk management and insurance. Singapore: McGraw-Hill, 1995.

YEMACK, D. Higher market valuation of firms with board of directors. Journal of Financial Economics, v. 40, n. 3, p. 185-211, 1996.

ZASK, Ezra. Global investment risk management - protecting international portfolios against currency, interest rate, equity, and commodity risk. New York: McGraw-Hill, 2000.

ZHANG, Yan; ZHOU, Jian; ZHOU, Nan. Audit committee quality, auditor independence, and internal control weaknesses. Working Paper, 2006. Disponível em <http://www.ssrn.com>. Acesso em: 14/07/2008. 


\section{APÊNDICES}

APÊNDICE 1 - COMMITTEE OF SPONSORING ORGANIZATIONS OF THE TREADWAY COMMISSION.

APÊNDICE 2 - EMPRESAS UTILIZADAS NA PESQUISA. 


\section{APÊNDICE 1 - COMMITTEE OF SPONSORING ORGANIZATIONS OF THE TREADWAY COMMISSION - COSO}

Em 1985, formou-se nos Estados Unidos uma comissão para estudar as causas de fraudes em relatórios contábeis. Referida comissão foi constituída como o nome de Commission on Fraudulent Financial Reporting e era uma iniciativa do setor privado que contava com a presença de representantes das principais associações de classe de profissionais ligados à área financeira.

Em 1987, a comissão acima se tornou The Committee of Sponsoring Organizations of the Treadway Commission - COSO com a incumbência de integrar os vários conceitos e definições sobre controles internos em um único documento que pudesse ser utilizado pelas companhias abertas, contadores públicos, legisladores e agências reguladoras.

O COSO, em 1992, emitiu o trabalho denominado Internal Control - Integrated Framework fornecendo uma definição para controles internos, bem como alguns critérios para possibilitar a avaliação dos riscos dos sistemas de controles internos. Citada definição é muito similar à divulgada pelo AICPA em 1988/1995:

\footnotetext{
Controle interno é um processo, estabelecido pelo conselho de administração, diretoria, gerência ou outras pessoas da companhia, desenhado para providenciar razoável segurança de que os seguintes objetivos sejam atingidos:

1. eficácia e eficiência das operações;

2. confiabilidade nos relatórios financeiros;

3. conformidade com leis e normas aplicáveis.
}

O primeiro objetivo está relacionado aos objetivos do negócio, incluindo desempenho, alcance de metas e salvaguarda de ativos. O segundo está direcionado para a preparação e confiabilidade das demonstrações financeiras, incluindo balancetes e relatórios financeiros consolidados. O terceiro objetivo visa à conformidade com leis e regulamentos para qualquer empresa sujeita aos mesmos.

No conceito do COSO o sistema de controles internos está estruturado em cinco componentes inter-relacionados: 
- $\quad$ Ambiente de controle: é a base da organização, influenciado a consciência de controle das pessoas. Este é o fundamento para os demais componentes de controle, promovendo disciplina e estrutura. O ambiente de controle incluir fatores de integridade, valores éticos e competência das pessoas da organização; filosofia administrativa e estilo de gerenciamento; a forma de delegação de autoridade e responsabilidade, a administração e desenvolvimento de pessoal; e o direcionamento recebido da alta administração;

- $\quad$ Avaliação de risco: é a identificação e análise de riscos relevantes a serem considerados para o alcance dos objetivos, formando a base para determinar como os riscos devem ser gerenciados;

- $\quad$ Atividades de controle: são as políticas e procedimentos que ajudam a garantir o alcance das orientações gerenciais. Ajudam a garantir que as ações necessárias para atingir os objetivos das entidades levam em consideração os riscos associados. Ocorrem em todos os níveis e em todas as funções, abrangendo aprovações, autorizações, verificações, reconciliações, revisões de desempenho operacional, salvaguarda de ativos e segregações de funções;

- Informação e Comunicação: as informações pertinentes devem ser identificadas, capturadas e comunicadas oportunamente para as pessoas responsáveis, sendo que todos devem conhecer suas próprias regras e sistema de controles internos, tão bem quanto suas atividades individuais. Este componente também inclui uma comunicação efetiva com grupos externos, como clientes, fornecedores, reguladores e acionistas;

- $\quad$ Monitoramento: inclui a avaliação da qualidade do desempenho da empresa como um todo, realizada pelo monitoramento das atividades, testes específicos ou a combinação de ambos, sendo que controles internos deficientes devem ser comunicados correntemente à alta administração.

Também foi salientado pelo COSO que o sistema de controles internos pode ser considerado efetivo se a alta administração tiver razoável confiança de que: a) ela conhece os objetivos operacionais a serem alcançados por todas as entidades; b) as demonstrações financeiras são preparadas com confiabilidade; c) há conformidade com leis e regulamentos.

Os objetivos e os componentes de um sistema de controles internos foram apresentados pelo COSO por meio de um cubo, ilustração 1, para facilitar o entendimento do interrelacionamento dos objetivos e componentes. 


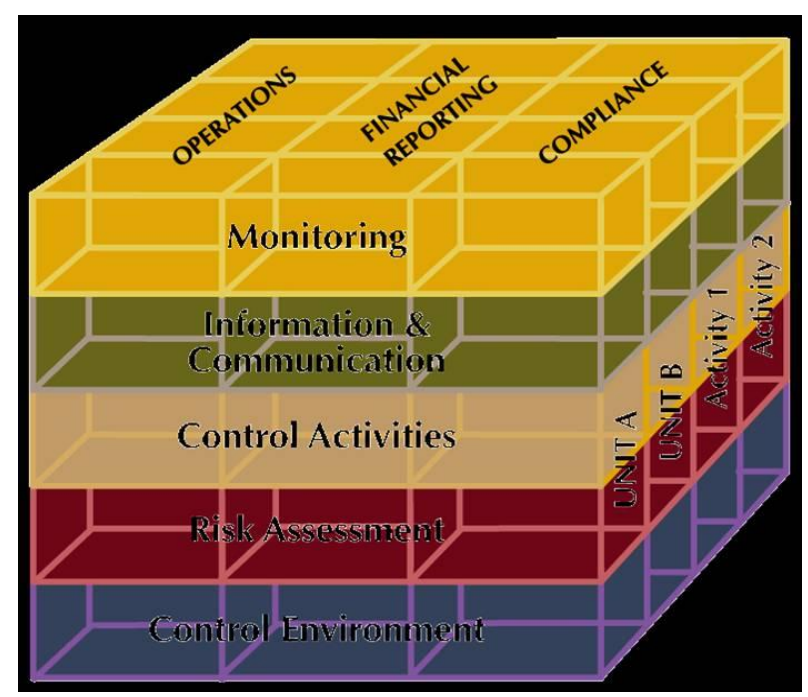

Ilustração 5 - Cubo COSO - Relacionamento entre objetivos e componentes

Em 2004, o COSO apresentou a conclusão de um novo trabalho intitulado Enterprise Risk Management - Integrated Framework (ERM) que havia sido iniciado em 2001. Este trabalho revisou e ampliou o modelo anterior, contudo não o revogou, conforme as palavras do comitê ao publicar o trabalho:

Este Enterprise Risk Management - Integrated Framework expande os controles internos, providenciando uma visão mais robusta e abrangente do amplo assunto que envolve o gerenciamento de risco de empreendimentos. Essa nova concepção não pretende e não substitui a estrutura de controles internos, mas a incorpora e permite às empresas aplicar esta nova estrutura de gerenciamento de riscos de empreendimentos para satisfazer tanto suas necessidades de controles internos como ampliar seus processos de gerenciamento de risco.

Na nova estrutura, foi adicionado o objetivo "Estratégia" que se refere aos objetivos de alto nível, alinhados com e sustentando a missão da empresa. Ademais, o componente "Ambiente de Controle" foi substituído por "Ambiente Interno" sem modificar sua definição. Também foram criados mais três componentes, além dos cinco já existentes, descritos a seguir:

- Estabelecimento de Objetivo: os objetivos devem ser definidos previamente, alinhados com a missão da organização, de forma que os riscos que os afetam sejam consistentes com o apetite ao risco da organização; 
- Identificação do Evento: os eventos internos e externos que afetam a realização dos objetivos da organização devem ser identificados e diferenciados entre riscos e oportunidades. As oportunidades são redirecionadas para os processos de definição de objetivos e estratégias;

- $\quad$ Resposta aos Riscos: a diretoria deve selecionar as ações a serem tomadas em relação aos riscos identificados, de forma que eles sejam evitados, aceitos, reduzidos ou compartilhados, em conformidade com os limites de tolerância ao risco da organização.

O COSO - ERM continuou utilizando a figura de um cubo, agora para representar a relação entre os objetivos, os componentes e as atividades desenvolvidas pelas organizações conforme pode ser visto na ilustração 3:

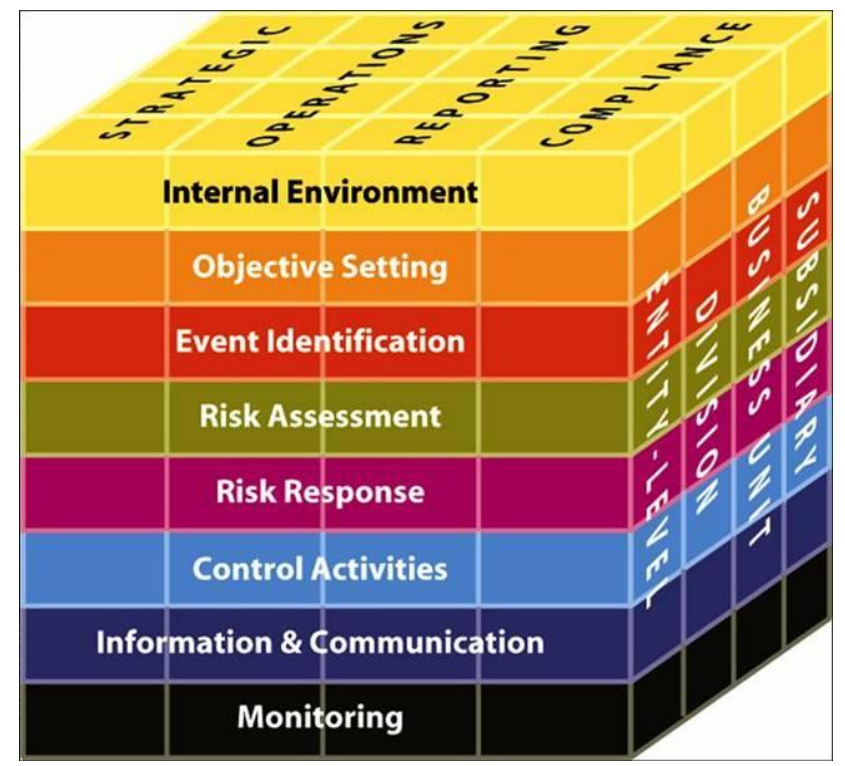

Ilustração 6 - Cubo Coso - Relacionamento entre objetivos, componentes e atividades

Importante ressaltar novamente que a estrutura básica do COSO vêm sendo utilizada pela grande maioria das empresas de capital aberto, mesmo porque o próprio PCAOB sugere sua utilização. 
APÊNDICE 2 - EMPRESAS UTILIZADAS NA PESQUISA

\begin{tabular}{|c|c|}
\hline SETOR ECONÔMICO & NOME DA EMPRESA \\
\hline Agro e Pesca & RASIP AGRO PASTORIL S.A. \\
\hline Alimentos e Bebidas & $\begin{array}{l}\text { CAFE SOLUVEL BRASILIA S.A. } \\
\text { CIA CACIQUE CAFE SOLUVEL } \\
\text { CIA LECO DE PRODS ALIMENTICIOS } \\
\text { CIA. IGUAÇU DE CAFÉ SOLÚVEL } \\
\text { COMPANHIA DE BEBIDAS DAS AMÉRICAS-AMBEV } \\
\text { CONSERVAS ODERICH S.A. } \\
\text { INDS J B DUARTE S.A. } \\
\text { JOSAPAR- JOAQUIM OLIVEIRA S/A PARTICIP } \\
\text { MINUPAR PARTICIPACOES S.A. } \\
\text { PARMALAT BRASIL S.A. IND.ALIM.EM REC.JUD. } \\
\text { PERDIGÃO S.A. } \\
\text { S.A. FABRICA PRODS ALIMCS VIGOR } \\
\text { SADIA S.A. }\end{array}$ \\
\hline Comércio & $\begin{array}{l}\text { COMPANHIA BRASILEIRA DE DISTRIBUIÇÃO } \\
\text { DIMED S.A. DISTRIBUIDORA DE MEDICAMENTOS } \\
\text { DROGASIL S.A. } \\
\text { GLOBEX UTILIDADES S.A. } \\
\text { GRAZZIOTIN S.A. } \\
\text { LOJAS AMERICANAS S.A. } \\
\text { LOJAS HERING S.A. } \\
\text { LOJAS RENNER S.A. } \\
\text { MINASMAQUINAS S.A. }\end{array}$ \\
\hline Construção & $\begin{array}{l}\text { AZEVEDO \& TRAVASSOS S.A. } \\
\text { CIMOB PARTICIPAÇÕES S/A } \\
\text { CONST ADOLPHO LINDENBERG S.A. } \\
\text { CONST LIX DA CUNHA S.A. } \\
\text { CONST SULTEPA S.A. } \\
\text { CONSTRUTORA BETER S/A. } \\
\text { CYRELA BRAZIL REALTY S.A. EMPRS E PARTS } \\
\text { GAFISA S/A } \\
\text { JOAO FORTES ENGENHARIA S.A. } \\
\text { MENDES JUNIOR ENGENHARIA S/A } \\
\text { SERGEN SERVS GERAIS DE ENG S.A. }\end{array}$ \\
\hline Eletroeletrônicos & $\begin{array}{l}\text { BRASMOTOR S.A. } \\
\text { ITAUTEC S.A-GRUPO ITAUTEC } \\
\text { SEMP TOSHIBA S.A. } \\
\text { SPRINGER S.A. }\end{array}$ \\
\hline
\end{tabular}




\begin{tabular}{|c|c|}
\hline SETOR ECONÔMICO & NOME DA EMPRESA \\
\hline Energia Elétrica & $\begin{array}{l}\text { AES SUL DISTRIB. GAUCHA DE ENERGIA S.A. } \\
\text { AES TIETE S.A. } \\
\text { CELG DISTRIBUIÇÃO S.A. - CELG D } \\
\text { CENTRAIS ELET BRASILEIRAS S.A. } \\
\text { CENTRAIS ELETRICAS DE SANTA CATARINA S.A. } \\
\text { CENTRAIS ELÉTRICAS DO PARÁ S.A.- CELPA } \\
\text { CENTRAIS ELÉTRICAS MATOGROSSENSES S.A } \\
\text { CESP - COMPANHIA ENERGÉTICA DE SAO PAULO } \\
\text { CIA ELETRICIDADE DA BAHIA } \\
\text { CIA ENERGETICA DE PERNAMBUCO } \\
\text { CIA ENERGÉTICA DO RIO GRANDE DO NORTE } \\
\text { CIA EST GERAÇÃO E TRANSM EN ELET CEEE-GT } \\
\text { CIA. ENERG. DE BRASILIA S.A. } \\
\text { COMPANHIA ENERGETICA DO CEARA - COELCE } \\
\text { COMPANHIA ENERGÉTICA DO MARANHÃO - CEMAR } \\
\text { COMPANHIA PARANAENSE DE ENERGIA } \\
\text { CTEEP-CIA TRANSM ENERGIA ELÉTR. PAULISTA } \\
\text { DUKE ENERGY INT,GERAÇÃO PARANAPANEMA S.A. } \\
\text { ELEKTRO ELETRICIDADE E SERVIÇOS S.A. } \\
\text { ELETROPAULO METROPOLITANA EL.S.PAULO S.A } \\
\text { EMAE-EMP.METROPOLITANA ÁGUAS ENERGIA S.A } \\
\text { INEPAR ENERGIA S/A } \\
\text { RIO GRANDE ENERGIA S.A. } \\
\text { TRACTEBEL ENERGIA S.A. }\end{array}$ \\
\hline Finanças e Seguros & $\begin{array}{l}\text { BANCO DA AMAZÔNIA S.A. } \\
\text { BANCO DO BRASIL S.A. } \\
\text { BANCO DO ESTADO DE SERGIPE S.A } \\
\text { BANCO DO ESTADO DO PIAUÍ S.A } \\
\text { BANCO ITAÚ HOLDING FINANCEIRA S.A. } \\
\text { BANESTES S/A BANCO ESTADO ESPÍRITO SANTO } \\
\text { BCO EST SANTA CATARINA S.A. } \\
\text { BCO MERCANTIL INVS S.A. } \\
\text { BRB-BANCO DE BRASILIA S.A. } \\
\text { CIA SEGUROS MINAS BRASIL } \\
\text { COMPANHIA DE SEGUROS ALIANCA DA BAHIA } \\
\text { FINANCEIRA ALFA S.A. - CFI } \\
\text { FINANSINOS S/A-CRÉDITO, FINAN. E INVEST. } \\
\text { MERCANTIL DO BR FINC S.A. CFI } \\
\text { RENNER PARTICIPACÕES S/A }\end{array}$ \\
\hline
\end{tabular}




\begin{tabular}{|c|c|}
\hline SETOR ECONÔMICO & NOME DA EMPRESA \\
\hline Máquinas Indust. & $\begin{array}{l}\text { BARDELLA S.A. INDS MECANICAS } \\
\text { INDÚSTRIAS ROMI S.A. } \\
\text { NORDON INDS METALURGICAS S.A. } \\
\text { WEG S.A. }\end{array}$ \\
\hline Mineração & $\begin{array}{l}\text { CIA VALE DO RIO DOCE } \\
\text { MAGNESITA S.A. }\end{array}$ \\
\hline Minerais não Met. & $\begin{array}{l}\text { CERAMICA CHIARELLI S.A. } \\
\text { ETERNIT S.A. } \\
\text { NADIR FIGUEIREDO IND. E COM. S/A } \\
\text { PORTOBELLO S.A. }\end{array}$ \\
\hline Outros & $\begin{array}{l}\text { ARTHUR LANGE S.A. IND E COM } \\
\text { BAUMER S.A. } \\
\text { CEMEPE INVESTIMENTOS S.A. } \\
\text { CIA BANDEIRANTES ARMS GERAIS } \\
\text { CIA CATARINENSE DE ÁGUAS E SANEAMENTO } \\
\text { CIA SANEAMENTO BÁSICO ESTADO SÃO PAULO } \\
\text { CIA. DE SANEAMENTO DO PARANÁ - SANEPAR } \\
\text { COMPANHIA HABITASUL DE PARTICIPAÇÕES } \\
\text { CONSÓRCIO ALFA DE ADMINISTRAÇÃO S.A. } \\
\text { DIXIE TOGA S. A. } \\
\text { DTCOM - DIRECT TO COMPANY S/A } \\
\text { DURATEX S.A. } \\
\text { EUCATEX S.A. IND E COMERCIO } \\
\text { GPC PARTICIPAÇÕES S.A } \\
\text { GRUÇAÍ PARTICIPAÇÕES S.A. } \\
\text { HOPI HARI S.A. } \\
\text { HOTEIS OTHON S.A. } \\
\text { IDEIASNET S/A } \\
\text { INVESTIMENTOS BEMGE S.A. } \\
\text { ITAITINGA PARTICIPACOES S.A. } \\
\text { ITAÚSA - INVESTIMENTOS ITAU S.A. } \\
\text { LARK S.A. MAQ E EQUIPAMENTOS } \\
\text { MANUF BRINQS ESTRELA S.A. } \\
\text { MONTEIRO ARANHA S.A. } \\
\text { NET SERVICOS DE COMUNICAÇÃO S.A. } \\
\text { PETROPAR S.A. } \\
\text { POLPAR S.A. } \\
\text { SANSUY S.A. IND.DE PLAST.EM REC.JUDICIAL } \\
\text { SÃO CARLOS EMPREEND. PARTICIPAÇÕES S.A. } \\
\text { SÃO PAULO TURISMO S/A }\end{array}$ \\
\hline
\end{tabular}




\begin{tabular}{|c|c|}
\hline & $\begin{array}{l}\text { SARAIVA S.A. LIVREIROS EDITORES } \\
\text { SAUIPE S.A. } \\
\text { SONDOTECNICA ENGENHARIA DE SOLOS S.A. } \\
\text { SOUZA CRUZ S/A } \\
\text { TEC TOY S/A } \\
\text { TECNOSOLO S/A } \\
\text { TELECOM BRASILEIRAS S.A. } \\
\text { TREVISA INVESTIMENTOS S.A. }\end{array}$ \\
\hline Papel e Celulose & $\begin{array}{l}\text { ARACRUZ CELULOSE S.A. } \\
\text { CELULOSE IRANI S.A. } \\
\text { KLABIN S.A. } \\
\text { MELPAPER S.A. } \\
\text { SUZANO PAPEL E CELULOSE S.A. } \\
\text { VOTORANTIM CELULOSE E PAPEL S.A. }\end{array}$ \\
\hline Petróleo e Gás & $\begin{array}{l}\text { CIA. BRAS PETRÓLEO IPIRANGA } \\
\text { CIA. DISTRIB. DE GÁS DO RIO DE JANEIRO } \\
\text { COMPANHIA DE GÁS DE SÃO PAULO - COMGÁS } \\
\text { PETRÓLEO BRASILEIRO S.A. - PETROBRAS } \\
\text { REFINARIA PET IPIRANGA S.A. } \\
\text { REFINARIA PET MANGUINHOS S.A. } \\
\text { WLM INDÚSTRIA E COMÉRCIO S.A. }\end{array}$ \\
\hline Química & $\begin{array}{l}\text { BRASKEM S.A. } \\
\text { ELEKEIROZ S.A. } \\
\text { FERTILIZANTES FOSFATADOS S.A. -FOSFERTIL } \\
\text { M\&G POLIÉSTER S.A. } \\
\text { MILLENNIUM INORGANIC CHEMICALS DO BRASIL } \\
\text { PETROFLEX INDÚSTRIA E COMÉRCIO S.A. } \\
\text { PRONOR PETROQUIMICA S.A. } \\
\text { ULTRAPAR PARTICIPAÇÕES S.A. } \\
\text { UNIPAR-UNIÃO INDS. PETROQUIMICAS S/A }\end{array}$ \\
\hline Siderurgia \& Metalurgia & $\begin{array}{l}\text { ACOS VILLARES S.A. } \\
\text { CARAIBA METAIS S.A. } \\
\text { CIA FERRO LIGAS BAHIA FERBASA } \\
\text { COMPANHIA SIDERÚRGICA NACIONAL } \\
\text { CONFAB INDUSTRIAL S.A. } \\
\text { ELUMA S.A. INDÚSTRIA E COMÉRCIO } \\
\text { FIBAM CIA INDUSTRIAL } \\
\text { FORJAS TAURUS S.A. } \\
\text { GAZOLA S.A. INDÚSTRIA METALURGICA } \\
\text { GERDAU S.A. } \\
\text { HAGA S.A. INDUSTRIA E COMERCIO } \\
\text { INDÚSTRIAS MICHELETTO S/A } \\
\text { MANGELS INDUSTRIAL S.A. }\end{array}$ \\
\hline
\end{tabular}




\begin{tabular}{|c|c|}
\hline & $\begin{array}{l}\text { METALGRAFICA IGUAÇU S.A. } \\
\text { METALURGICA DUQUE S.A. } \\
\text { MUNDIAL S/A - PRODUTOS DE CONSUMO } \\
\text { PARANAPANEMA S.A. } \\
\text { SIDERURGICA J L ALIPERTI S.A. } \\
\text { TEKNO S.A. CONSTR. INDÚSTRIA E COMÉRCIO }\end{array}$ \\
\hline & $\begin{array}{l}\text { AMAZONIA CELULAR S.A. } \\
\text { AMERICEL S/A } \\
\text { BRASIL TELECOM S.A. } \\
\text { EMBRATEL PARTICIPAÇÕES S.A. }\end{array}$ \\
\hline Telecomunicações & $\begin{array}{l}\text { INEPAR TELECOMUNICAÇÕES S/A } \\
\text { LA FONTE TELECOM S/A } \\
\text { LF TEL S/A } \\
\text { TELE NORTE CELULAR PARTICIPAÇÕES S.A. } \\
\text { TELECOMUNICAÇÕES DE SÃO PAULO S/A-TELESP } \\
\text { TELEMAR NORTE LESTE S/A } \\
\text { TELEMIG CELULAR PARTICIPAÇÕES S.A. } \\
\text { TELEMIG CELULAR S.A. } \\
\text { VIVO PARTICIPAÇÕES S/A. }\end{array}$ \\
\hline Têxtil & $\begin{array}{l}\text { BUETTNER S.A. IND E COMERCIO } \\
\text { CAMBUCI S.A. } \\
\text { CIA HERING } \\
\text { CIA INDL CATAGUASES } \\
\text { CIA INDL SCHLOSSER S.A. } \\
\text { CIA TECIDOS NORTE DE MINAS - COTEMINAS } \\
\text { CIA. DE FIACAO E TECIDOS CEDRO CACHOEIRA } \\
\text { DOHLER S.A. } \\
\text { EMP.NAC.C., RÉDITO E PART. S.A. ENCORPAR } \\
\text { FAB TECIDOS CARLOS RENAUX S.A. } \\
\text { FIACAO E TECELAGEM SAO JOSE S.A. } \\
\text { GUARARAPES CONFECÇÕES S.A. } \\
\text { KARSTEN S.A. } \\
\text { MARISOL S.A. } \\
\text { SÃO PAULO ALPARGATAS S.A. } \\
\text { TEKA TECELAGEM KUEHNRICH S.A. } \\
\text { TÊXTIL RENAUXVIEW S.A. } \\
\text { VICUNHA TÊXTIL S.A } \\
\text { VULCABRAS S/A. }\end{array}$ \\
\hline Transporte Serviços & $\begin{array}{l}\text { ALL - AMERICA LATINA LOGISTICA S.A. } \\
\text { CIA DOCAS DE IMBITUBA } \\
\text { COMPANHIA DE CONCESSÕES RODOVIÁRIAS } \\
\text { TAM S.A. }\end{array}$ \\
\hline
\end{tabular}




\begin{tabular}{|l|l|}
\hline SETOR ECONÔMICO & NOME DA EMPRESA \\
\hline Veículos e peças & BICICLETAS MONARK S.A. \\
& COBRASMA S.A. \\
& DHB IND E COMERCIO S.A. \\
& EMBRAER EMPR BRAS. DE AERONAUTICA S.A \\
& FRAS-LE S.A. \\
& INDS ARTEB S.A. \\
& IOCHPE-MAXION S.A. \\
& MAHLE METAL LEVE S.A. \\
& MARCOPOLO S.A. \\
& METALURGICA RIOSULENSE S.A. \\
& PLASCAR PARTICIPAÇÕES INDUSTRIAIS S.A \\
& RANDON S.A. IMPLEMENTOS E PARTICIPAÇÕES \\
& SCHULZ S.A \\
& TUPY S.A. \\
\hline
\end{tabular}

